Jessica Alves

Modelo de otimização robusta orientado por dados aplicado na alocação de renda fixa

Dissertação de Mestrado

Dissertação apresentada como requisito parcial para obtenção do grau de Mestre pelo Programa de Pós-Graduação em Engenharia de Produção do Departamento de Engenharia Industrial da PUC-Rio.

Orientador: Prof. Davi Michel Valladão 
Jessica Alves

\section{Modelo de otimização robusta orientado por dados aplicado na alocação de renda fixa}

Dissertação apresentada como requisito parcial para obtenção do grau de Mestre pelo Programa de Pós-Graduação em Engenharia de Produção da PUC-Rio. Aprovada pela Comissão Examinadora abaixo assinada.

Prof. Davi Michel Valladão

Orientador

Departamento de Engenharia Industrial - PUC-Rio

Prof. Betina Dodsworth Martins Froment Fernandes MBA em Gestão de Investimentos - IAG/PUC-Rio

Prof. Frances Fischberg Blank

Departamento de Engenharia Industrial - PUC-Rio

Prof. Márcio da Silveira Carvalho

Coordenador (a) Setorial do Centro

Técnico Científico - PUC-Rio

Rio de Janeiro, 27 de abril de 2017. 
Todos os direitos reservados. É proibida a reprodução total ou parcial do trabalho sem autorização da autora, do orientador e da universidade.

Jessica Alves

Graduou-se em Engenharia de Produção pela Universidade Federal do Rio de Janeiro (UFRJ) em 2013. Aluna de mestrado da PUC-Rio desde março de 2015. Faz parte da linha de pesquisa em Finanças e Análise de Investimentos.

Ficha Catalográfica

Alves, Jessica

Modelo de otimização robusta orientado por dados aplicado na alocação de renda fixa / Jessica Alves; orientador: Davi Michel Valladão - 2017.

92 f. : il. color. ; $30 \mathrm{~cm}$

Dissertação (mestrado) - Pontifícia Universidade Católica do Rio de Janeiro, Departamento de Engenharia Industrial, 2017.

Inclui bibliografia

1. Engenharia Industrial - Teses. 2. Otimização robusta. 3. Gestão de portfólio. 4. Estrutura a termo da curva de juros. 5. Títulos de renda fixa. 6. Data-driven. I. Valladão, Davi Michel. II. Pontifícia Universidade Católica do Rio de Janeiro. Departamento de Engenharia Industrial. III. Título. 


\section{Agradecimentos}

À Deus pela vida, pela sabedoria e por me amparar nos momentos difíceis. Todo conhecimento é Dele e se não fosse por Sua vontade eu não teria realizado esse mestrado.

Aos meus pais, expresso todo o meu agradecimento pelo amor, pelos valores e por todo o esforço na minha formação pessoal e profissional. Seus ensinamentos me fizeram acreditar na importância do desenvolvimento intelectual.

À minha irmã, pelas palavras de incentivo e pelo apoio à realização deste projeto tão desejado.

Ao Davi, por me orientar na elaboração desse projeto, pela disponibilidade do seu tempo em me ajudar, pela sua dedicação e sua paciência em todo o período que trabalhamos juntos.

Ao Carlos Patrício Samanez (in memoriam), por ter compartilhado um pouco da sua vasta experiência em finanças e análise de investimentos e por todo o suporte no mestrado. Possuía o dom de ensinar e inspirar seus alunos.

Aos professores do DEI/PUC-Rio pela qualidade de ensino e por terem compartilhado parte dos seus conhecimentos.

Aos meus amigos da PUC, que espero levar para toda a vida, pelas trocas de ideias e por terem mostrado que a experiência acadêmica não se limita às paredes da sala de aula.

À CAPES (Coordenação de Aperfeiçoamento de Pessoal de Nível Superior) e à PUC-Rio (Bolsas PUC-Rio/VRAC), pela concessão das bolsas que me permitiram ter esta oportunidade de aprendizado e de desenvolver um trabalho científico.

À PUC, por me permitir desenvolver esse trabalho e pela excelência estrutural do seu ambiente. 


\section{Resumo}

Alves, Jessica; Valladão, Davi Michel (Orientador). Modelo de otimização robusta orientado por dados aplicado na alocação de renda fixa. Rio de Janeiro, 2017. 92p. Dissertação de Mestrado - Departamento de Engenharia Industrial, Pontifícia Universidade Católica do Rio de Janeiro.

Este trabalho propõe um modelo de otimização robusta de pior caso orientado por dados aplicado na seleção de um portfólio de títulos de renda fixa. A gestão das carteiras implica na tomada de decisões financeiras e no gerenciamento do risco através da seleção ótima de ativos com base nos retornos esperados. Como estes são variáveis aleatórias incertas foi incluído um conjunto definido de incertezas estimadas diretamente no processo de otimização, chamados de cenários. Foi usado o modelo de ajuste de curvas Nelson \& Siegel para construir as estruturas a termo das taxas de juros empregadas na precificação dos títulos, um ativo livre de risco e alguns ativos com risco de maturidades diferentes. Os títulos prefixados são marcados a mercado porque estão sendo negociados antes do prazo de vencimento. A implementação ocorreu pela simulação computacional usando dados de mercado e dados estimados que alimentaram o modelo.Com a modelagem de otimização robusta foram realizados diferentes testes como: analisar a sensibilidade do modelo frente às variações dos parâmetros verificando seus resultados e a utilização de um horizonte de janela rolante para simular o comportamento ao longo do tempo. Obtidas as composições ótimas das carteiras, foi feito o backtesting para avaliar o comportamento das alocações com o retorno real e também a comparação com o desempenho de umbenchmark. Os resultados dos testes mostraram a adequação do modelo da curva de juros e bons resultados de alocação do portfólio robusto, que apresentaram confiabilidade até em períodos de crise.

\section{Palavras-chave}

Otimização robusta; gestão de portfólio; estrutura a termo da curva de juros; títulos de renda fixa; data-driven. 


\section{Abstract}

Alves, Jessica; Valladão, Davi Michel (Advisor). Data-driven robust optimization model applied for fixed income allocation. Rio de Janeiro, 2017. 92p. Dissertação de Mestrado - Departamento de Engenharia Industrial, Pontifícia Universidade Católica do Rio de Janeiro.

This paper proposes a data-driven worst case robust optimization model applied in the selection of a portfolio of fixed income securities. The portfolio management implies in financial decision-making and risk management through the selection of optimal assets based on expected returns. As these are uncertain random variables, was included a defined set of estimated uncertainties directly in the optimization process, called scenarios. The Nelson \& Siegel curve fitting model was used to construct the term structure of the interest rates employed in the pricing of securities, a risk-free asset and some risky assets of different maturities. The fixed-rate securities are marked to market because they are being traded before the maturity date. The implementation took place through computational simulation using market data and estimated data that fed the model. With robust optimization modeling were done different tests such as: analyze the sensitivity of the model to the variations of the parameters checking the results and the use of a rolling horizon scheme to simulate behavior over time. Once the optimal portfolio composition was obtained, the backtesting was done to evaluate the behavior of the allocations with the real return and also the comparison with the performance of a benchmark. The results of the tests showed the adequacy of the interest curve model and good allocation results of the robust portfolio, which presented reliability even in times of crisis.

\section{Keywords}

Robust optimization; portfolio management; term structure of the interest curve; fixed income securities; data-driven. 


\section{SUMÁRIO}

1 Introdução

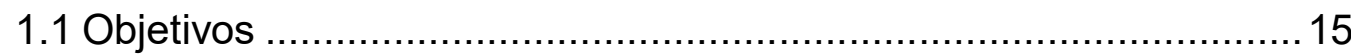

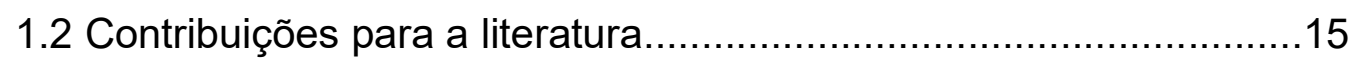

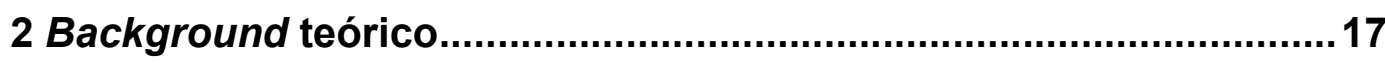

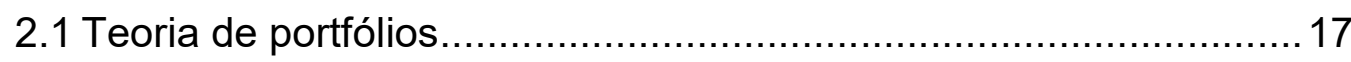

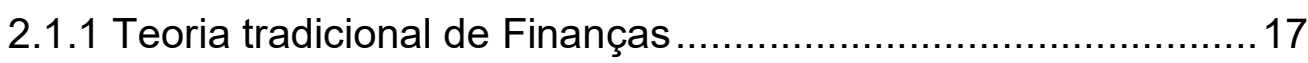

2.1.2 Finanças modernas: modelo de média variância de Markowitz 18

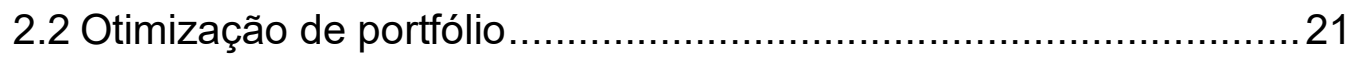

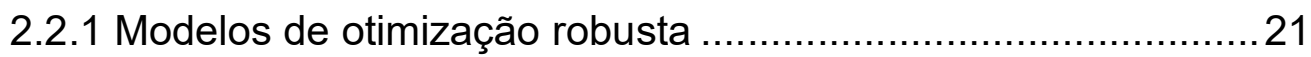

2.2.2 Problema robusto de otimização de média variância.................23

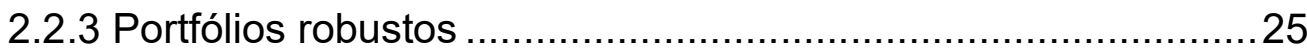

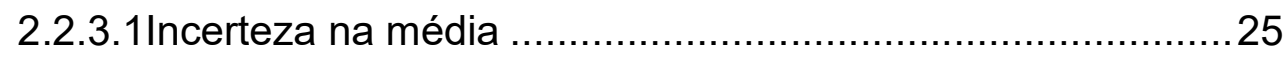

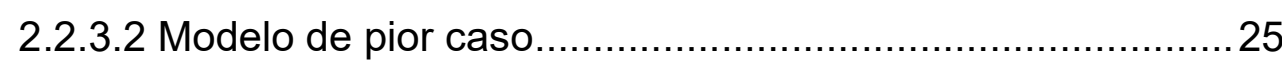

2.3 Investimentos de renda fixa......................................................... 31

2.3.1 Principais taxas de Juros no Brasil: CDI e Selic .......................36

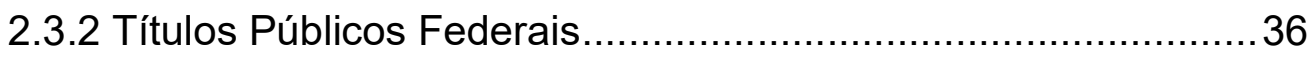

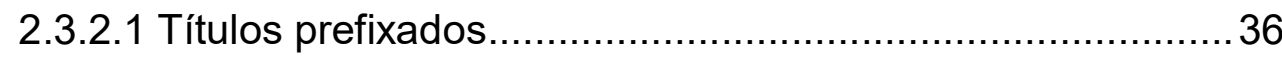

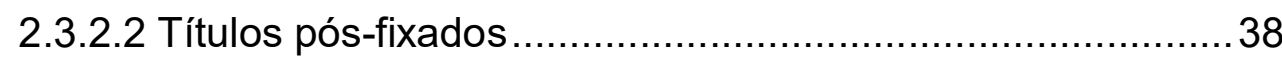

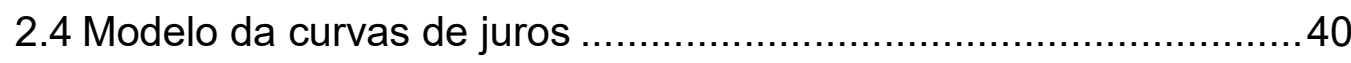

2.4.1 Modelo de Nelson \& Siegel (1987) ...................................... 41

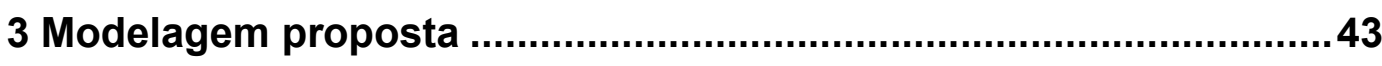

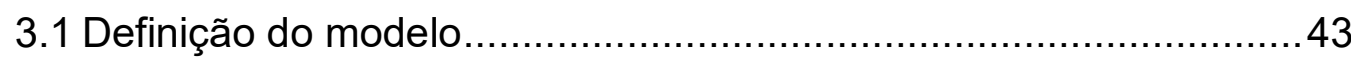

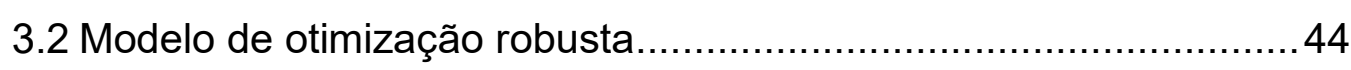

3.3 Entradas para o modelo: Taxa PRE DI .......................................46

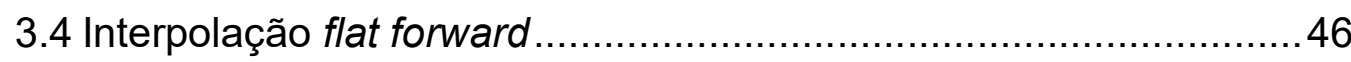

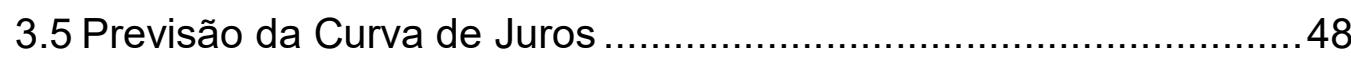

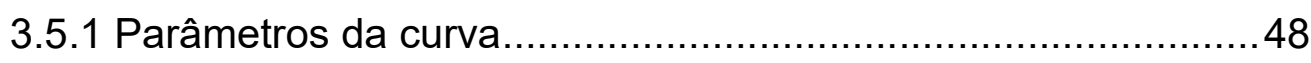

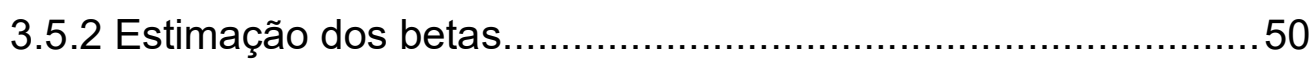

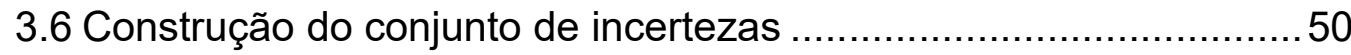

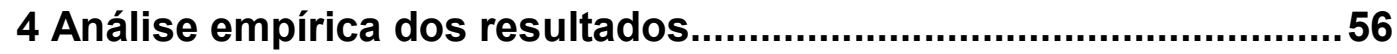

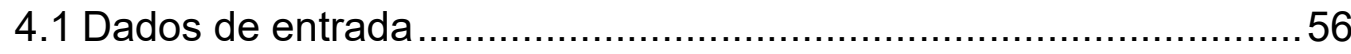

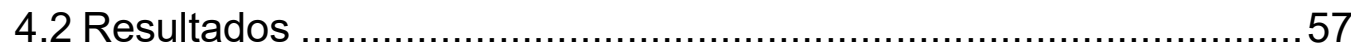


4.2.1 Estimação dos valores dos betas ...................................57

4.2.2 Evolução das taxas de juros por maturidades no tempo ........58

4.2.3 Curvas de juros estimadas e curva de juros real ..................59

4.3 Resultados da otimização ................................................63

4.3.1 Análise do retorno de cada ativo..................................... 71

4.3.2 Sensibilidade do retorno pela quantidade de cenários ............67

4.3.2.1 Efeito da variação da quantidade de cenários no retorno ......70

4.3.3 Backtesting .............................................................. 71

4.3.4 Crise e sem crise ...................................................... 75

4.3.5 Lâmina de fundo de investimento ..................................... 79

4.3.5.1 Trailing Return (períodos de 3M, 6M e 1A).....................80

4.3.5.2 Desempenho do fundo como percentual do CDI252 .........82

4.3.6 Índice Sharpe .............................................................. 84

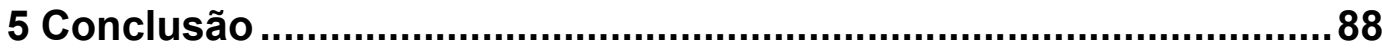

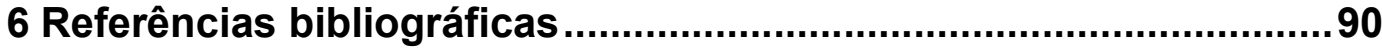




\section{Lista de figuras}

Figura 1: Conjunto incerteza de Soyster. ................................................28

Figura 2: Conjunto incerteza de Ben-Tal e Nemirovski. .........................29

Figura 3: Conjunto incerteza de Bertsimas e Sim. ..................................30

Figura 4: Conjunto incerteza de Fernandes et al.....................................31

Figura 5: Fluxo de pagamentos do Tesouro Prefixado. ...........................37

Figura 6: Fluxo de pagamentos Tesouro Selic. ....................................... 38

Figura 7: Fluxograma da modelagem proposta. ................................. 44

Figura 8: Representação da Interpolação Flat Forward. ........................47

Figura 9: Evolução dos coeficientes dos betas. .................................... 49

Figura 10: Evolução dos betas no tempo. .............................................57

Figura 11: Evolução das taxas extraídas da Bloomberg por maturidades

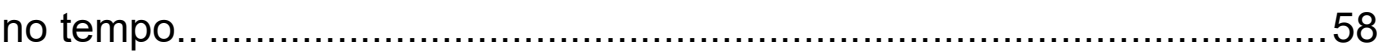

Figura 12: Evolução das taxas calculadas pelo modelo por maturidades

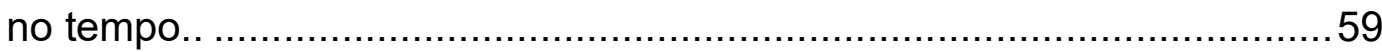

Figura 13: Variabilidade do retorno dos ativos......................................64

Figura 14: Sensibilidade do retorno pela quantidade de cenários.............68

Figura 15: Alocação dos ativos em cada quantidade de cenários..............71

Figura 16: Alocação dos ativos e rentabilidade acumulada ao longo do

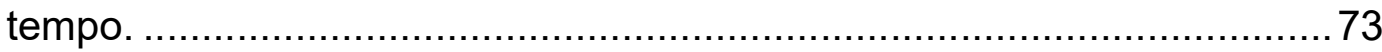

Figura 17: Análise de crise - Retorno LP e CP (\%) .............................76

Figura 18: Retorno dos ativos - Dia sem crise.....................................77

Figura 19: Retorno dos ativos - Dia com crise .........................................77

Figura 20: Retorno dos ativos - Dia com crise (sem ativo livre de risco).. 78

Figura 21: Alocação ao longo do tempo - Estratégia Arrojada..................85

Figura 22: Alocação ao longo do tempo - Estratégia Conservadora. ........86 


\section{Lista de Gráficos}

Gráfico 1: Sensibilidade do preço em função da taxa. .............................34

Gráfico 2: Marcação a mercado de títulos (caso LTN)............................. 35

Gráfico 3: Comparação da curva de juros de dados observados com a

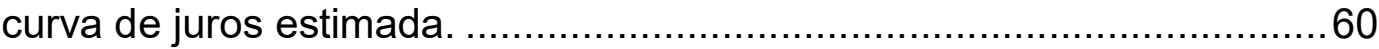

Gráfico 4: Comparação curva de juros - dia 12/04/2016.........................61

Gráfico 5: Comparação curva de juros - dia 02/12/2015. .........................61

Gráfico 6: Comparação curva de juros - dia 02/12/2015.........................62

Gráfico 7: Comparação curva de juros - dia 15/03/2015 ..........................62

Gráfico 8: Comparação curva de juros - dia 04/02/2015.........................63

Gráfico 9: Curva de juros e previsões das curvas..................................65

Gráfico 10: Curva de juros e previsões das curvas - Pessimista..............66

Gráfico 11: Curva de juros e previsões das curvas - Otimista..................66

Gráfico 12: Curva de juros e previsões das curvas - Realista. ................67

Gráfico 13: Retorno da carteira pela quantidade de cenários. ..................70

Gráfico 14: Rentabilidade da carteira $\mathrm{x}$ rentabilidade do DI. ....................74

Gráfico 15: Patrimônio acumulado comparado com o DI acumulado........79

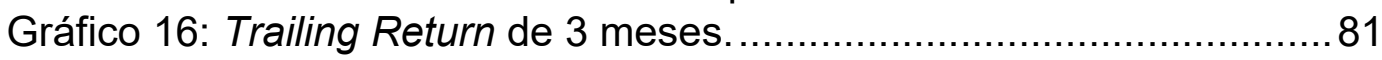

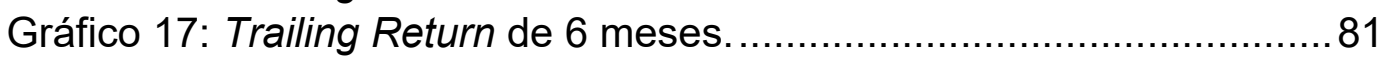

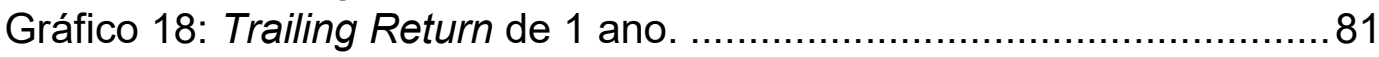

Gráfico 19: Desempenho do fundo em percentuais do CDI252 - 3m.......82

Gráfico 20: Desempenho do fundo em percentuais do CDI252 - $6 \mathrm{~m}$.......83

Gráfico 21: Desempenho do fundo em percentuais do CDI252 - 1 ano. . 83 


\section{Lista de Tabelas}

Tabela 1: Índice Sharpe das estratégias -3 meses.

.86

Tabela 2: Índice Sharpe das estratégias -6 meses.

Tabela 3: Índice Sharpe das estratégias - 1 ano. 


\section{Introdução}

A gestão de carteiras de investimento através do processo da seleção ótima de ativos busca atingir rentabilidade superior ao índice de mercado do seu segmento e ao mesmo tempo controlar o nível de risco desejado. A aplicação real de técnicas de otimização para seleção de carteiras é um desafio para gestoras de fundos de investimentos. É preciso antecipar o movimento do mercado, utilizando modelos de otimização que possam obter alocações ótimas de portfólios baseado nas previsões de retorno.

A otimização robusta é usada como instrumento para a tomada de decisões e a realização de planejamento nas áreas de finanças e de estratégia, sendoamplamente utilizada para problemas de alocação de capital em carteiras de ativos financeiros. Em termos de metodologia e aplicação tem a vantagem de não tratar os retornos como parâmetros conhecidos, utilizando a estimação de um conjunto de possíveis valores, pois assume que a estimativa realizada pode conter uma margem de erro. Quando o retorno é tratado como um valor conhecido existe o risco de concretização de um valor diferente que violará as restrições da otimização e fará uma alocação de uma carteira que terá um desempenho ruim (KLEIN; BAWA, 1976). Trata-se de um modelo mais aderente com a realidade e permite a aplicação prática.

Markowitz é o responsável pela base da teoria moderna do portfólio fundamental para a decisão de investimentos (MARKOWITZ, 1952). Cada investimento apresenta uma expectativa de retorno para um nível de risco e é necessário balancear a escolha dos ativos através do perfil do investidor. Para se expor a um maior risco é preciso ser oferecido um prêmio de risco, mas depende da disposição do perfil em aceitar ou não. A busca pela combinação que permite maximizar a utilidade esperada do indivíduo é baseada no trade-off entre o risco e o retorno, considerando o grau de aversão ao risco do indivíduo.

A teoria de utilidade esperada (NEUMANN; MORGENSTERN, 1944) é a teoria econômica predominante para explicar decisões sob incerteza. Em 
condições de incerteza as decisões racionais exigem que as pessoas utilizem e processem todas as informações disponíveis de um modo lógico e sistemático, e tomem decisões totalmente racionais, optando por um conjunto de preferências sob aversão ao risco e que visando a maximização da sua utilidade.

Sharpe constrói seus estudos baseado nas premissas de que o investidor é racional, avesso ao risco e sempre procura maximizar seu bem estar (SHARPE, 1964). Os erros que podem ser cometidos pelos investidores são aleatórios e não são resultantes de uma tendência para o otimismo ou para o pessimismo. As finanças modernas baseiam-se em modelos de risco-retorno e partem do princípio da racionalidade do investidor e da eficiência do mercado.

Com a necessidade de introduzir as incertezas do mercado real às técnicas tradicionais de seleção de portfólio que trabalhavam com valores determinísticos, surgiram novas teorias de otimização estocástica e de otimização robusta. Soyster (1973) foi o pioneiro dos modelos de otimização robusta, seguido por autores com expressivos trabalhos e com larga disseminação. Dentre eles, os mais relevantes foram Ben-tal e Nemirovski (2000) e Bertsimas e Sim (2004). Os autores divergem na complexidade e no conservadorismo adotado em relação à incerteza dos parâmetros, mas apresentaram técnicas que incorporam o conjunto de incerteza delimitado no modelo.

Nesse trabalho é desenvolvido um modelo de otimização robusto de pior caso que permite apoiar decisões de alocação de uma carteira de renda fixa. A carteira que tem o melhor dentre os piores casos de retorno garante um desempenho superior caso se concretize o pior cenário possível considerado no conjunto de incerteza dos retornos. Trata-se uma técnica por natureza conservadora, mas que impossibilita alocações que possam ocasionar as piores perdas.

O modelo criado é orientado por dados e tem abordagem quantitativa que captura o efeito do movimento das taxas de juros na precificação dos títulos que será usada para realizar a previsão dos retornos de cada ativo. A construção da curva a termo da taxa de juros é realizada com base em dados de mercado coletados usando o modelo Nelson \& Siegel (1987). Posteriormente, aprevisão das curvas a frente da data de análise também é realizada utilizando estimações.

O investidor, ao selecionar uma alternativa de investimento, toma uma decisão antes de saber o valor de seu retorno. Apenas depois de realizado o 
investimento que se pode auferir os resultados. Por isso não é possível criar um caso real estipulando um retorno certo determinístico. Portanto é então construir um conjunto de incerteza dos retornos que é incorporado diretamente no modelo de otimização e será um conjunto de dados preestabelecido e limitado, que representa os cenários de estimação e a alocação ótima deve satisfazer simultaneamente todas as restrições. Assim a quantidade de cenários expressa o nível de conservadorismo.

O mercado de títulos públicos federais oferece títulos prefixados e pósfixados corrigido por um indexador. São investimentos considerados seguros e largamente utilizados pela facilidade de negociação oferecida, pela alta liquidez e pelo baixo risco de crédito. No modelo, eles serão empregados em negociações sem serem mantidos até o vencimento e representam alguns ativos com risco de diferentes maturidades e um ativo livre de risco. Se uma posição pode gerar perdas então existe risco. Em função disso, a utilização de um ativo livre de risco como alternativa para a composição da carteira permite diminuir a parcela do risco total do investimento. $\mathrm{O}$ risco da posição combinada de ativos é inferior ou igual à média ponderada dos riscos individuais, conforme o princípio da diversificação de carteiras (ARTZNER et al., 1999).

O mercado brasileiro tem alta volatilidade na taxa de juros o que gera oportunidade de ganhos expressivos, mas também podendoacarretar perdas acentuadas. Se houver uma gestão eficiente de ativos existe potencial para a obtenção de desempenho superior ao benchmark de referência.

A abordagem considera a execução de vários testes para serem realizadas análises de comportamento e de evolução do modelo baseado em decisões de alocação diárias, sejam pontuais ou com o método de horizonte rolante, no qual a janela de estimação se movimenta. O número de cenários também é um parâmetro decisivo para a alocação e serãoexaminadas as suas variações. O backtesting da carteira permite avaliar a performance e simular um fundo de investimento com as informações necessárias para julgar o desempenho das alocações ótimas.

O presente trabalho está dividido em cinco capítulos. O primeiro capítulo consiste na introdução do tema da pesquisa e nos objetivos principais que justificaram o desenvolvimento desse projeto. O segundo capítulo apresenta a revisão bibliográfica da literatura que fornecerá o contexto teórico no qual está inserido esse projeto para embasar e possibilitar a compreensão do 
modelodesenvolvido na sequência. O terceiro capítulo apresenta a modelagem proposta e o quarto capítulo os resultados dos testes empíricos da otimização robusta de todos os estudos de casos realizados. No quinto capítulo sãoapresentadas as conclusões desse trabalho com ênfase no desempenho do modelo sintetizando o que foi mais relevante. Por fim, o último capítulo é composto pelas referências bibliográficas.

\section{1}

\section{Objetivos}

O objetivo principal desse trabalho é elaborar um modelo de otimização robusta na metodologia de pior caso para apoiar a decisão de alocação de portfólios que se ajustem à gestão de ativos de renda fixa no mercado brasileiro. Foram usadas técnicas de estimação e modelagem, com implementação computacional.

Para atingir esse objetivo fez-se necessário:

- Modelar a curva da taxa de juros nominal e estudar como o seu comportamento afeta o retorno dos ativos e consequentemente a composição da carteira ótima.

- Desenvolver o processo de criação do modelo de otimização: das variáveis aleatórias, da função objetivo e das restrições.

- Desenvolver simulações usando como fonte de entrada os dados históricos e os modelos matemáticos para alimentar o modelo de otimização com as informações necessárias, dado que todo esse estudo é orientado por dados.

- Criar cenários a serem usados de forma simultânea para traduzir as incertezas das condições de mercado em um conjunto de valores viáveis. Para isso foi necessário prever a expectativa da taxa de juros futura usada na precificaçãodos títulos e no cálculo dos seus retornos, tendo assim os insumos para tomar decisões de investimentos que se adequem ao movimento do mercado.

- Realizar testes para possibilitar a interpretação financeira de um portfólio de diferentes formas estratégicas de análise. Nesse contexto, também avaliar a performance dos resultados através de backtesting e o desempenho de benchmarks, de forma a verificar a robustez do modelo e 
contribuir para a literatura da pesquisa quantitativa aplicada na área de otimização robusta.

\section{2}

\section{Contribuições para a literatura}

A literatura aborda de várias perspectivas a alocação de ativos financeiros e também os modelos de otimização robusta aplicado às finanças, mas existe uma lacuna para implementação do modelo de otimização robusta de pior caso aplicado ao mercado renda fixa de títulos públicos federais no Brasil. Os estudos na área se concentram tradicionalmente no mercado de renda variável por ser o queapresenta maior volatilidade. Portando, a contribuição desejada com esse trabalho é expandir a aplicação para este instrumento financeiro de extrema relevância e representatividade no mercado financeiro.

Este trabalho busca auxiliar à gestão de carteiras o usode ferramentas que garanta a robustez e possibilitamatingir rentabilidade maior que o benchmark de referência do mercado de renda fixa para investidores e fundos de investimentos. 


\section{2 \\ Background teórico}

\section{1}

\section{Teoria de portfólios}

Uma carteira de investimento, também conhecida por portfólio, é um conjunto de ativos financeiros com características distintas como maturidade, taxa de juros e forma de rendimento. A base da análise financeira tradicional é a formação de carteiras de investimentos capazes de oferecer retornos superiores aos índices médios de mercado porque se supõe que o mercado nem sempre está certo, com isso é possível ganhar dinheiro descobrindo situações em que o mercado está errado.

Em outras palavras, os modelos de avaliação de ativos na análise tradicional de finanças tentam revelar a ocorrência de má precificação pelo mercado, o que permite ao investidor "ganhar" do mercado através da incorporação de ativos subavaliados ou da eliminação da má precificação dos ativos sobrevalorizados.

\subsection{1}

\section{Teoria tradicional de Finanças}

A teoria de Finanças tradicional considera que os mercados estão sujeitos a comportamentos irracionais. Considera-se que um mercado se comporta de forma irracional quando muitos investidores estão muito otimistas e dispostos a pagar o que os ativos não valem, ou muito pessimistas quando não estão dispostos a pagar o que os ativos valem em relação ao seu fluxo de caixa descontado.

Os observadores de mercado são chamados de analistas técnicos (grafistas) e trabalham com séries históricas de preços e traçam gráficos para projetar o comportamento dos investidores para prever a direção do mercado. Os selecionadores de títulos são chamados de analistas fundamentalistas e trabalham 
buscando identificar títulos sub ou sobreavaliados usando as informações disponíveis das variáveis do mercado.

Os analistas fundamentalistas e os analistas técnicos fazem parte da mesma escola apesar das divergências entre eles e das críticas mútuas existentes. Os analistas técnicos consideram que todas as informações relevantes para previsão do preço de um ativo se encontram nas séries de preços e qualquer outra informação é irrelevante. Já analistas fundamentalistas calculam o valor presente dos fluxos de caixa futuro de um determinado investimento e qualquer desvio deste valor calculado significa que as ações estão subavaliadas ou superavaliadas.

A crítica à teoria tradicional de finanças é que a análise técnica considera que os preços do passado são a melhor previsão para os preços no futuro e a análise fundamentalista projeta resultados futuros, baseados em dados do passado das empresas.

Enquanto as finanças tradicionais nasceram no dia-a-dia do mercado financeiro, as finanças modernas nasceram dentro da Academia e de lá seguiram para o mundo do mercado financeiro.

\subsection{2}

Finanças modernas: modelo de média-variância de Markowitz

Markowitz é o fundador das finanças modernas. Ele define que um portfólio de investimento consiste em um conjunto de ativos cada qual representado por uma proporção específica do capital e, com isso, resultando em níveis agregados de retorno e risco. Uma decisão ótima equivale à maximização da utilidade esperada do investidor que pode ser traduzido como maior retorno com menor risco.

Segundo Markowitz (1952), todo investimento apresenta um retorno esperado e uma variância de possíveis resultados em torno deste retorno esperado. Ele considerou o retorno como desejável e a variância como indesejável, de modo que as decisões de investimentos referentes à seleção de portfólio devem ser baseadas na relação risco-retorno. Assim, montou um modelo de programação quadrática capaz de maximizar os retornos e minimizar a variância dado um nível de retorno. O retorno é uma variável aleatória e a carteira é uma combinação de ativos que tem pesos ponderados. 
Ao analisar um determinado ativo, um investidor deveria preocupar-se não com o risco do ativo individual, mas com a sua contribuição ao risco total da carteira. A combinação de todos os ativos com risco resultaria numa curva, na qual seria possível detectar uma fronteira eficiente, sendo esta o conjunto de carteiras com a melhor relação entre risco e retorno.

A fronteira eficiente é composta pelo conjunto de carteiras que os investidores racionais irão escolher pelo princípio da diversificação. Essa fronteira é composta pelas carteiras ótimas que representam a escolha do maior retorno para o mesmo nível de risco. Entretanto só uma carteira é ótima para cada perfil buscado de investimento que é determinado pela exposição ao risco escolhida. Quanto maior for o risco do investimento, maior deverá ser o seu retorno.

Markowitz considerava que existiam dois riscos no mercado financeiro: o risco sistemático e o risco não sistemático. O risco sistemático se refere ao risco do mercado como um todo, não podendo ser eliminado pela diversificação de investimentos. O risco não sistemático se refere ao risco que afeta somente um ativo ou um grupo especifico de ativos e este risco pode ser minimizado pela diversificação. Apesar de defender a diversificação, Markowitz mostrou que se existir uma forte correlação positiva entre os retornos dos ativos não se teriam os resultados esperados pela diversificação.

A teoria de portfólio causou uma ruptura nas finanças tradicionais, pois, embasado pelos conceitos de risco recomendava a diversificação dos investimentos para redução da variância, contrariando o senso comum que recomendava a concentração dos recursos em único ativo de maior retorno esperado. E também considerou que os investidores não poderiam obter, de forma consistente, uma rentabilidade superior à do mercado já que este não pode ser previsto. Essa teoria busca selecionar uma carteira ótima que maximize o retorno esperado para determinado nível de risco ou então minimize o risco esperado para determinado retorno, conforme equação (1) e equação (2). 


$$
\begin{array}{cl}
\text { maximizar } & \sum_{i=1}^{n} \mu_{i} x_{i} \\
& \sum_{i=1}^{n} x_{i}^{2} \sigma_{i}^{2}+\sum_{i=1}^{n} \sum_{j=1 ; i \neq 1}^{n} x_{i} x_{j} \sigma_{i j} \leq \sigma_{M} \\
& \sum_{i=1}^{n} x_{i}=1 \\
& \leq x_{i} \leq 1 \\
\text { minimizar } & \sum_{i=1}^{n} x_{i}^{2} \sigma_{i}^{2}+\sum_{i=1}^{n} \sum_{j=1 ; i \neq 1}^{n} x_{i} x_{j} \sigma_{i j} \\
& \sum_{i=1}^{n} \mu_{i} x_{i} \geq R_{m} \\
& \sum_{i=1}^{n} x_{i}=1 \\
& 0 \leq x_{i} \leq 1
\end{array}
$$

Sendo:

$i=$ cada ativo

$x_{i}=$ percentual alocado em cada ativo correspondente

$\mu_{i}=$ retorno esperado de cada ativo correspondente

$\sigma_{i}=$ volatilidade de cada ativo, sendo $\sigma_{i}^{2}$ a variância

$\sigma_{i j}=$ covariância entre os ativos $i$ e $j$

$R_{m}=$ retorno mínimo aceito

$\sigma_{M}=$ risco máximo aceito

O modelo de Markowitz é conhecido por média-variância porque ele usa como medida de desempenho o retorno médio esperado e como medida de risco a variância. Outro ponto importante é a correlação entre os ativos que precisa ser menor que um para ter uma diversificação. (KOLM; TÜTÜNCÜ; FABOZZI, 2014). 


\section{2 \\ Otimização de portfólio}

Os modelos de otimização estão desempenhando um papel cada vez mais importante nos estudos e nas atividades de finanças e na análise de investimentos. A alocação de ativos em carteiras ótimas e a gestão de risco são resolvidas com técnicas modernas de otimização usando problemas matemáticos e ferramentas computacionais. Trata-se de uma abordagem científica voltada para a tomada de decisões financeiras (CORNUEJOLS; TÜTÜNCÜ, 2006). A seleção de portfólios através da otimização consiste em alocar percentuais aos ativos selecionados, usando na maioria das vezes como dados de entrada estimativas para os retornos aleatórios dos ativos. Ao modelar o processo de decisão é preciso definir a função objetivo, as variáveis de decisão e as restrições.

Os modelos usam dados reais para simular situações reais e possibilitar o gerenciamento dos riscos junto com o esforço de obter o maior retorno que satisfaça as restrições impostas. Um modelo eficaz incorpora as preferências do seu criador e utiliza conceitos de diversificação. De forma auxiliar é fundamental o uso de outras técnicas que darão o suporte para o tratamento das informações que serão utilizadas no modelo como: modelos de ajustes de curvas, técnicas quantitativas, medição de risco, previsão de retornos, entre outros.

Sharpe (1971) foi um dos pioneiros a utilizar algoritmos otimizados e sugeriu a adequação do modelo de média-variância em um modelo de programação linear para facilitar as aplicações práticas (SHARPE, 1971).

As soluções da otimização são baseadas nos dados de entrada, podem ocorrer deles não serem estimados corretamente, terem erros na sua colocação ou serem usadas informações incompletas. Nesse caso, podem ocorrer uma grande alteração na alocação ótima (LU, 2011). Essa alta sensibilidade da variação das entradas dos modelos acaba influenciando o resultado ótimo obtido, que perde sua otimalidade na prática.

\subsection{1}

\section{Modelos de otimização robusta}

Sempre que houver incerteza associada a um resultado, esta é uma situação de risco e a tomada de decisões deve ser cuidadosa. Nesse contexto, é necessário 
criar métodos para mensurar as variações possíveis com modelos matemáticos que possibilitem estruturar uma forma mais robusta de lidar com o problema (DUPAČOVÁ; KOPA, 2014).

A abordagem clássica da alocação de ativos em um portfólio trabalha com todas as entradas do modelo de otimização sendo determinísticas (DEMIGUEL; NOGALES, 2007), sendo que pequenas variações nos dados de entrada mudam a decisão de alocação. Com isso, não há margem para erro e se for concretizado qualquer valor diferente do estabelecido no modelo, a solução tida como ótima irá violar as restrições, de modo que e todo esforço gasto na criação do modelo e na sua implementação serão perdidos. Em casos de implementação real ainda podem ocorrer consequências maiores como perda de capital, mau dimensionamento de estrutura, más previsões logísticas, entre outras.

$\mathrm{Na}$ otimização robusta, a incerteza dos parâmetros é formalizada através do conjunto de incertezas, que é formado pela imprecisão dos valores futuros de certos parâmetros (BEN-TAL; NEMIROVSKI, 1998). Estes são estimados por técnicas estatísticas e matemáticas a partir de dados históricos, ou por outras técnicas. Um dos tipos mais comuns desses conjuntos de incerteza é representado por uma envoltória convexa de um número finito de cenários gerados para os possíveis valores dos parâmetros. O tamanho do conjunto de incertezas será escolhido com base no nível desejado de robustez. (CORNUEJOLS; TÜTÜNCÜ, 2006) (GREGORY; DARBY-DOWMAN; MITRA, 2011).

Soyster (1973) foi o grande precursor dos modelos de otimização robusta. Ele apresentou um modelo de otimização linear com um conjunto de incerteza convexo predefinido para todos os parâmetros. Essa parte da otimização ficou conhecida como otimização robusta exatamente por isso. A incorporação das incertezas no modelo permite que se ache uma solução em que são consideradas todas elas simultaneamente.

$\mathrm{Na}$ área econômica essa abordagem ganhou força devido à relevância e à adequabilidade para os problemas que enfrenta. As decisões financeiras são voltadas para o futuro e, portanto, não são tomadas em condições de certeza, principalmente no que tange os resultados. Os modelos de otimização robustos incorporam um conjunto de incerteza dos retornos na prática da alocação de ativos. A otimização robusta concede uma margem para o modelo com a 
determinação de um possível intervalo em que são considerados cenários do que pode acontecer no futuro, previnindo alocações que podem trazer grandes perdas.

Os modelos de otimização robusta necessitam de desenvolvimento computacional e por isso a sua complexidade é muito importante, pois o custo de implementação de modelos não lineares é muito maior, inviabilizando o uso em larga escala (BERTSIMAS; PACHAMANOVA, 2008).

A otimização robusta é baseada em um conjunto de incertezas delimitado e convexo, sendo que as escolhas ótimas estão nos vértices do conjunto. $\mathrm{O}$ modelo robusto incorpora a incerteza dos erros da estimação diretamente no processo de otimização (FABOZZI et al., 2007).

Por outro lado, a programação estocástica também utiliza o conceito de incerteza, mas usa variáveis aleatórias com distribuição de probabilidade conhecida. Usualmente,os modelos fazem a otimização sobre cenários de possíveis realizações para as entradas aleatórias. A função objetivo pode ser otimizada em média ou a otimização pode incluir penalidades para violação de restrição e considerações de risco (FABOZZI et al., 2007).

Em problemas como gestão de ativos é necessário ter um modelo que possa ser usado com dados reais e tenha abertura para lidar com as incertezas do mercado e retornar soluções robustas para facilitar a tomada de decisões. O modelo robusto deixa de ser sensível a pequenas variações porque ele já as considerou na sua estrutura (SANTOS, 2010).

\subsection{2}

\section{Problema robusto de otimização de média variância}

Segundo (TÜTÜNCÜ; KOENIG, 2004) os problemas de alocação ótima de ativos podem ser formulados matematicamente usando a programação quadrática parametrizadas, podendo ser representados por:

(i) Minimização da variância sujeita a um limite inferior sobre o retorno esperado:

$$
\begin{array}{cc}
\min _{x \in \mathcal{R}^{n}} & x^{T} Q x \\
\text { s. } a & \mu^{T} x \geq R \\
& x \in \chi
\end{array}
$$


(ii) Maximização do retorno esperado ajustado ao risco:

$$
\begin{array}{cc}
\max _{x \in \mathcal{R}^{n}} & \mu^{T} x-\lambda x^{T} Q x \\
\text { S. } a & x \in \chi
\end{array}
$$

O primeiro é parametrizado pelo limite de retorno esperado e o segundo pelo parâmetro de aversão ao risco, onde $\mu$ é o vetor dos retornos esperados dos ativos, Q é a matriz de covariância desses retornos e $\mathrm{x}_{\mathrm{i}}$ são os componentes do vetor $\mathrm{x}$ que indicam a proporção da carteira a ser investida no ativo i.

$\mathrm{Na}$ equação (3), $\mathrm{R}$ é o limite inferior do retorno esperado que se deseja alcançar e $\chi$ representa o conjunto poliédrico de carteiras viáveis, aquelas que satisfazem as restrições lineares impostas. Na equação (4), o escalar $\lambda$ representa o parâmetro de aversão ao risco e a função objetivo representa uma função de retorno esperada ajustada ao risco. Resolvendo uma das equações (3) e (4) para diferentes valores de $\mathrm{R}$ e $\lambda$, respectivamente, gera-se uma sequência de carteiras ótimas na fronteira eficiente.

O fato dos portfólios ótimos serem muito sensíveis aos parâmetros de entrada $\mu$ e Q, faz com que seja importante adotar uma estratégia que represente a informação disponível sobre os parâmetros de entrada desconhecidos na forma de um conjunto de incertezas, que contenha os valores possíveis para eles.

Dado o conjunto de incertezas $\mathcal{U}_{\mu}$ da média e $\mathcal{U}_{Q}$ da variância, as versões robustas dos problemas de otimização da média-variância das equações (3) e (4) foram expressas por (GOLDFARB; IYENGAR, 2003) e (HALLDÓRSSON; TÜTÜNCÜ, 2003), respectivamente, como:

$$
\begin{array}{cc}
\min & \max _{\mathrm{Q} \in \mathcal{U}_{Q}} x^{T} Q x \\
\text { s.a } & \min _{\mu \in \mathcal{U}_{\mu}} \mu^{T} x \geq R \\
x \in \chi & \\
\max _{x \in \chi} & \min _{\mu \in \mathcal{U}_{\mu}, \mathrm{Q} \in \mathcal{U}_{Q}} \mu^{T} x-\lambda x^{T} Q x
\end{array}
$$




\subsection{3}

\section{Portfólios robustos}

De acordo com (FABOZZI; HUANG; ZHOU, 2010)(FABOZZI et al., 2007)(FABOZZI; PACHAMANOVA， 2016)(FABOZZI; PACHAMANOVA, 2010), a otimização robusta lida com a incerteza nos coeficientes dos problemas de otimização resolvendo as suas contrapartes robustas, que são problemas de otimização formulados em termos das realizações do pior caso dos parâmetros incertos dentro de conjuntos de incertezas pré-estabelecidos. Considerando uma restrição linear:

$$
\tilde{a}^{\prime} x \leq b
$$

A contrapartida robusta dessa restrição linear será:

$$
\max _{a \in \mathcal{U}_{\delta}(\hat{\mathrm{a}})}\left\{a^{\prime} x\right\} \leq b
$$

Essa expressão significa que é exigido que a restrição seja satisfeita mesmo para o pior caso de $a^{\prime} x$, tendo $a$ variado no conjunto de incertezas especificado. $\mathrm{O}$ valor do pior caso é obtido no máximo porque se o valor máximo de $a^{\prime} x$ é menor ou igual a $b$, então a restrição é satisfeita para todos os valores menores de $a^{\prime} x$.

Se a desigualdade for oposta, temos:

$$
\tilde{a}^{\prime} x \geq b
$$

E a contraparte robusta seria:

$$
\min _{a \in \mathcal{U}_{\delta}(\hat{\mathrm{a}})}\left\{a^{\prime} x\right\} \geq b
$$

Então o pior caso aconteceria no mínimo da expressão $a^{\prime} x$.

\subsubsection{1}

\section{Incerteza na média}

Para incorporar a incerteza causada por erros no cálculo da estimativa pode-se exigir que o investidor tenha proteção se o retorno esperado estimado para cada 
ativo $i$ tiver um valor próximo ao verdadeiro retorno esperado. Pode-se supor assim que o erro da estimação não seja maior do que algum valor pequeno não negativo, $\delta_{\mathrm{i}}>0$.

a) "Caixa"

É a escolha mais simples para o conjunto incerto da média $\mu$ :

$$
\mathcal{U}_{\delta}(\hat{\mu})=\left\{\mu \|\left|\mu_{i}-\hat{\mu}_{i}\right| \leq \delta_{i}, i=1, \ldots, N\right\}
$$

$\mathrm{O} \delta_{\mathrm{i}}$ pode estar relacionado a um intervalo de confiança em torno do retorno esperado estimado $\left(\hat{\mu}_{\mathrm{i}}-\delta_{\mathrm{i}}, \hat{\mu}_{\mathrm{i}}+\delta_{\mathrm{i}}\right)$. Por exemplo, se o retorno individual dos ativos de risco é normalmente distribuído, então $\frac{\mu_{i}-\widehat{\mu}_{i}}{\sigma_{i} / \sqrt{N_{i}}}$ segue uma distribuição normal padrão e um intervalo de confiança de $95 \%$ para $\mu_{\mathrm{i}}$ pode ser obtido por ajuste $\delta_{i}=1.96 \sigma_{i} / \sqrt{N_{i}}$, onde $N_{i}$ é o tamanho da amostra usado na estimativa, número de ativos, e $\sigma_{\mathrm{i}}$ é o desvio padrão do ativo $i$.

$\mathrm{O}$ conjunto incerteza acima define que o coeficiente $\mu_{\mathrm{i}}$ pode assumir qualquer valor entre $\hat{\mu}_{\mathrm{i}}-\delta_{\mathrm{i}}$ e $\hat{\mu}_{\mathrm{i}}+\delta_{\mathrm{i}}$. O $\delta_{\mathrm{i}}$ representa a metade do comprimento do intervalo de confiança formado em torno da estimativa $\hat{\mu}^{\mathrm{i}}$.

O problema robusto da carteira pode ser formulado:

$$
\min _{x \in X}\left\{x^{\top} \mathrm{Qx}: \min _{\mu} \mu^{\mathrm{T}} \mathrm{x} \geq \mu_{0},\left|\mu_{i}-\hat{\mu}_{i}\right| \leq \delta_{i}, \forall i=1, \ldots, N\right\}
$$

b) Elipsoidal

O conjunto incerto de $\mu$ será:

$$
\mathcal{U}_{\delta}(\hat{\mu})=\left\{\mu \|(\mu-\hat{\mu})^{\prime} \Sigma_{\mu}^{-1}(\mu-\hat{\mu}) \leq \delta^{2}\right\}
$$

Se $\delta^{2}$ é correspondente ao valor do percentil $\omega$ de uma distribuição $\chi^{2}$ com $\mathrm{n}$ graus de liberdade iguais ao número de ativos na carteira.

$$
\min _{x \in X}\left\{x^{\top} \Sigma x: \min _{\mu} \mu^{\mathrm{T}} \mathrm{x} \geq \mu_{0},(\mu-\hat{\mu})^{T} \Sigma^{-1}(\mu-\hat{\mu}) \leq \chi^{2}\right\}
$$




\subsubsection{2}

\section{Modelo de pior caso}

Diante de um panorama incerto é necessário considerar todos os cenários, em particular o de pior caso. Em problemas financeiros, por questões de proteção de patrimônio é sempre bom evitar que a sua carteira fique exposta a alocações que potencializem o pior cenário (RUSTEM; HOWE, 2002). O modelo de pior caso é recomendado quando a problemática precisa de um controle de risco, pois é incorporado diretamente no modelo o conjunto de incerteza dos cenários de retorno definido.

O modelo pode ser definido como:

- Minmax, onde se minimiza o pior caso. Como pior caso podemos entender perda máxima.

- Maxmin, onde se maximiza o retorno mínimo.

Ou seja, ambos significam a melhor solução possível assumindo a possibilidade de acontecer o pior cenário possível.

$\mathrm{O}$ conjunto de incerteza tem a variabilidade já definida com os valores permitidos e compondo um número finito de cenários. Assim, está preparado para qualquer um dos cenários que possa se realizar, um grupo de possibilidades e não apenas para um cenário específico, dada as hipóteses assumidas (TÜTÜNCÜ; KOENIG, 2004).

Sendo a função objetivo colocada em função da alocação e de todas as incertezas:

$$
\begin{array}{ll}
\min _{x} & \left(\underset{r \in \Omega}{\max } r_{i} x_{i}\right) \\
\text { s.a } & A x \leq b
\end{array}
$$

Dado o conjunto de incerteza $\Omega$ e $x$ é a variável de decisão.

São atribuídos valores a $x$ baseado nos cenários futuros, ou seja, antes do dado real ser realizado. Na otimização robusta não são permitidas violações das restrições. Devem-se estimar os potenciais cenários para o problema e as restrições são tratadas na otimização de modo que não se atinja o pior caso. Com isso, o modelo escolhe uma solução subótima, mas se protege quanto à incerteza dos parâmetros. 
Os três grandes trabalhos referências desse método são:

O modelo de Soyster (1973) é muito conservador porque considera o pior cenário possível se concretizando para todos os parâmetros incertos simultaneamente. Esse conjunto de parâmetros forma um intervalo fechado com amplitude simétrica e centro no valor esperado, formato "caixa". A função objetivo retorna resultados muito pessimistas, pois os valores ótimos assumem sempre os extremos do intervalo de incertezas, mas é simples de ser implementada. Quanto maior for a amplitude do intervalo dos parâmetros incertos maior será o número de possíveis cenários futuros. Sendo $\mathrm{a}_{\mathrm{ij}} \mathrm{o}$ valor esperado para o parâmetro e $\hat{a}_{\mathrm{ij}}$ a amplitude do intervalo de inexatidão (SOYSTER, 1973), o conjunto de incertezas é dado pela Figura 1.

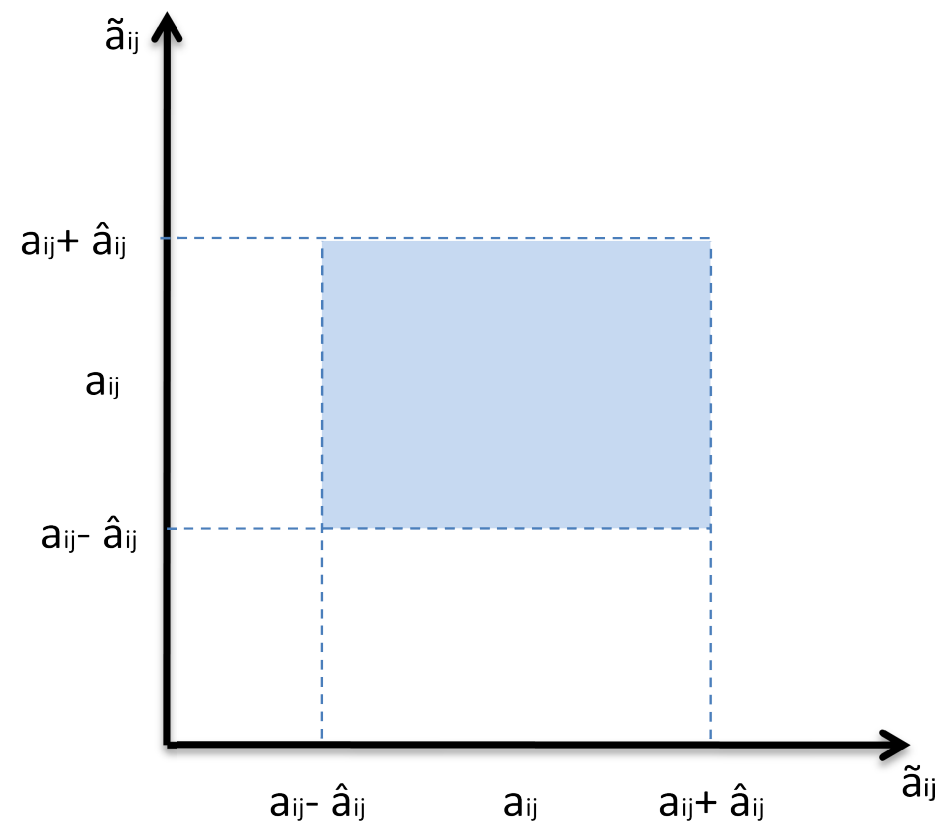

Figura 1: Conjunto incerteza de Soyster. Fonte: Elaboração própria.

Ben-Tal e Nemirovski (2000) em seu estudo propuseram um modelo para reduzir o conservadorismo da solução robusta com a definição de um intervalo de incerteza elipsoidal que não considera todos os parâmetros assumindo os piores casos simultaneamente. A desvantagem é que a técnica mais complexa por ser um programa não linear cônico de segunda ordem(BEN-TAL; NEMIROVSKI, 1999). O conjunto é apresentado na Figura 2. 


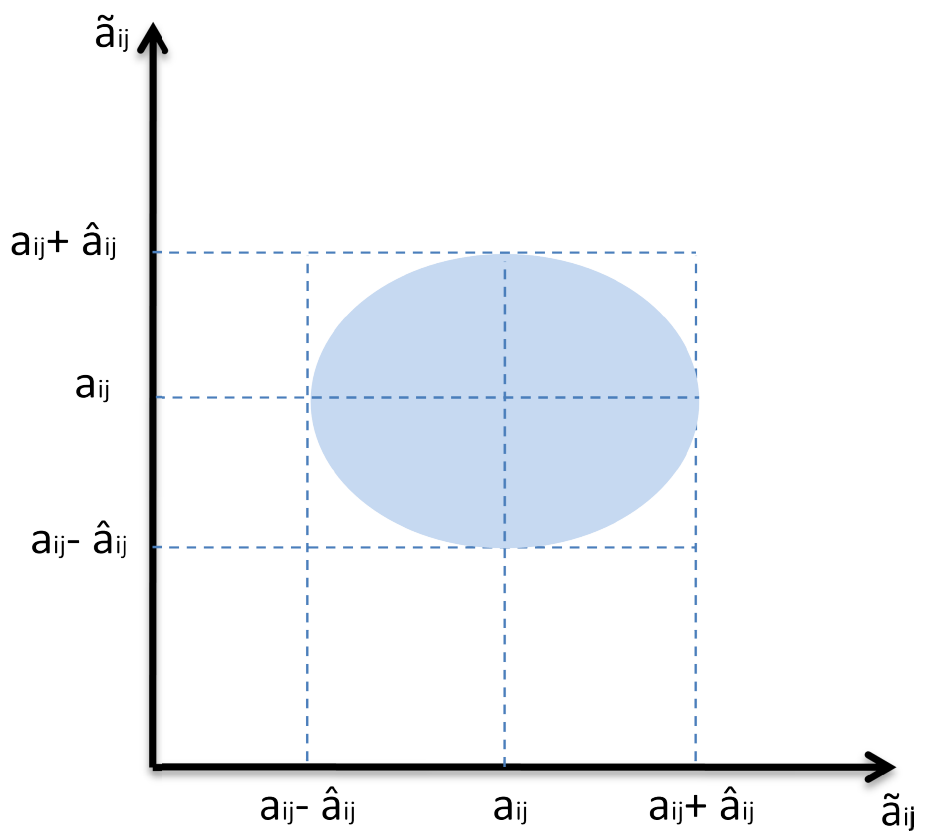

Figura 2: Conjunto incerteza de Ben-Tal e Nemirovski. Fonte: Elaboração própria.

Bertsimas e Sim (2004) buscaram reduzir o conservadorismo e conceder simplicidade ao modelo. A definição do intervalo dos parâmetros incertos é similar à de Soyster (1973) do ponto de vista da simetria e estar com o centro no valor esperado. Mas nessa abordagem o conjunto de incertezas é limitado com o auxilio de um parâmetro $\Gamma_{i}$ que seleciona apenas um intervalo de valores do conjunto incerteza que poderão assumir o valor de pior caso. Quanto menor for o valor do parâmetro $\Gamma_{i}$, menor será a variação possível entre os parâmetros incertos e os seus valores nominais, o que possibilita um maior controle do conservadorismo. O modelo também apresenta linearidade o que facilita sua implementação (BERTSIMAS; SIM, 2004). O conjunto é apresentado na Figura 3. 


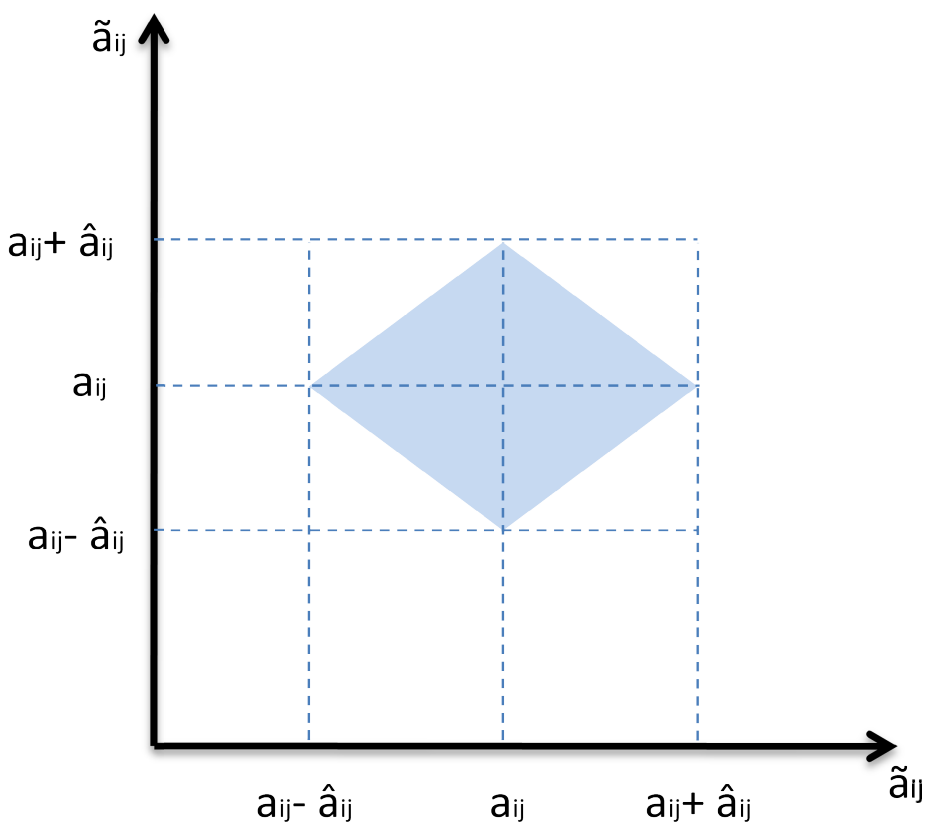

Figura 3: Conjunto incerteza de Bertsimas e Sim. Fonte: Elaboração própria.

Os autores mudaram o formato do conjunto de incerteza paramétrico para expressar o controle do nível de conservadorismo, pois este nível depende da variabilidade dos parâmetros. Além disso, a linearidade nesse tipo de problema é importante porque ela permite criar estruturas mais complexas com um maior número de restrições sem ter que enfrentar a complexidade computacional que dificulta a inviabilidadodo uso do modelo. Adicionalmente, o tamanho do conjunto garante a probabilidade do parâmetro incerto assumir um valor existente no conjunto (BERTSIMAS; SIM, 2004)(FABOZZI; HUANG; ZHOU, 2010).

O modelo do presente projeto é uma nova perspectiva do artigo de (FERNANDES et al., 2016). O trabalho trata de um modelo de otimização robusto de carteiras de investimentos impulsionado em dados. As incertezas são definidas em um conjunto poliédrico adaptativo composto pelos retornos dos ativos que são previstos em um esquema de horizonte rolante e que alimentam o modelo de otimização diretamente incorporando a incerteza no processo de otimização. A metodologia foi adaptada para ativos de renda fixa nesse estudo, mas foram desconsiderados os custos de transação.

A figura 4 representa o conjunto de incerteza do modelo que são os retornos diários previstos dos ativos de risco. Esses são os vértices que formam uma região poliédrica convexa e delimitada que inclui todos os cenários gerados 
no conjunto. O modelo apresenta linearidade e tem seu grau de conservadorismo limitado por um limite de perda intuitivo.

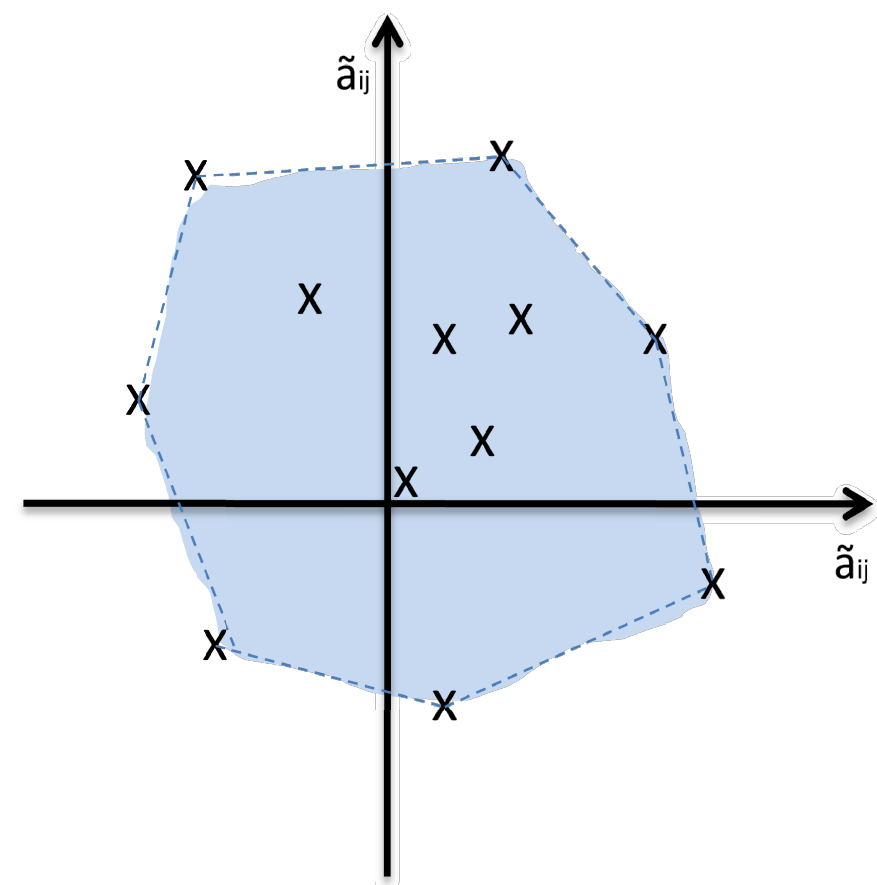

Figura 4: Conjunto incerteza de Fernandes et al. Fonte: Elaboração própria.

\section{3}

\section{Investimentos de renda fixa}

\subsection{1 \\ Principais taxas de Juros no Brasil: CDI e Selic}

O CDI e a Selic são duas taxas usadas e que têm papel muito importante no modelo desenvolvido nesse trabalho, assim como na economia brasileira.

A regra internacional, conhecida como Acordo de Basileia, exige que as instituições financeiras encerrem o dia com o caixa positivo para que não haja risco de quebra sistêmica. Quando uma instituição tem a necessidade de pegar dinheiro emprestado de outra para não fechar no negativo são emitidos títulos pelas instituições financeiras com o objetivo de transferir recursos entre elas. Esses títulos são conhecidos como Certificados de Depósito Interbancários (CDI) que são empréstimos de curtíssimo prazo (1 dia) e garantem ao banco credor da dívida que o banco emissor irá arcar com o empréstimo.

O CDI é um título com lastro nos títulos do Tesouro Direto e por isso tem rentabilidade que flutua em torno da Selic. A taxa CDI ou DI1 é a taxa de 
remuneração na negociação entre as instituições financeiras. A taxa DI1 é apurada e divulgada diariamente pela Câmara de Custódia e Liquidação (CETIP). Ela é cotada diariamente como a média das operações ocorridas em um único dia e expressa por dia útil em ano-base de 252 dias úteis.

Os investimentos considerados mais seguros do mercado usam a taxa DI1 como referência, assim ela é conhecida como taxa livre de risco. Ela é usada como benchmark principalmente de investimentos de renda fixa, ou seja, o desempenho das carteiras é comparado ao CDI e com base nisso são avaliados como rentáveis ou não. Um bom investimento possui performance superior ao CDI. Mas o investidor não pode investir diretamente em CDI, para ele estão disponíveis opções de renda fixa que rendem um percentual pré-acordado do CDI. O CDI é negociado exclusivamente entre instituições financeiras.

A taxa Selic é a taxa média ponderada de remuneração apurada no Sistema Especial de Liquidação e de Custódia (Selic) para títulos federais. Essa taxa é cotada diariamente e expressa por dia útil em ano-base de 252 dias úteis. Ela é conhecida como taxa básica de juros, porque toda instituição financeira norteia os juros de empréstimos a partir do seu valor.

O banco pega dinheiro emprestado do Tesouro Nacional ao custo da Selic e empresta esse dinheiro ao custo da Selic adicionado de um spread. Quanto maior for o valor da Selic mais caro será conseguir o empréstimo do banco. Por isso a Selic serve como termômetro da economia, o mercado se movimenta quando a Selic aumenta ou diminui e o investidor deve considerar fazer realocações em suas carteiras para proteger o seu patrimônio.

As taxas de juros Selic e DI1 são resultado do produto verificado ao longo do período:

$$
i_{t}^{n}=\left[\prod_{j=1}^{n}\left(1+\frac{i_{j}}{100}\right)^{\frac{1}{252}}\right]^{\frac{252}{n u}}
$$

\section{Onde:}

$n=$ maturidade

$n u=$ número de dias úteis no período de cálculo 
$i_{t}^{n}=$ taxa de juros Selic ou DI1 (ao ano)

$i_{j}=$ taxa de juro referente ao j-ésimo dia

\subsection{2}

\section{Títulos Públicos Federais}

O mercado derenda fixaconsiste em instrumentos financeiros que possuem condições de rentabilidade determinados no momento da aplicação. São definidos também os prazos e as formas de remuneração. Os riscos desses investimentos costumam ser menores e garantem alguma previsibilidade de remuneração.

Os títulos públicos federais são ativos de renda fixa emitidos pelo governo federal com a finalidade de arrecadar recursos para o financiamento da dívida pública e servir como instrumentos de política monetária. Eles são considerados investimentos mais conservadores e seguros. Ao realizar a compra, são acordadas as taxas de juros que serão aplicadas e com isso já fica conhecida a rentabilidade até o vencimento, mas isso não quer dizer que os seus preços e as suas taxas não sofrem variação ao longo do tempo.

Os títulos são garantidos pelo Governo Federal e representam a alternativa de investimento de menor risco do mercado se mantidos até os seus vencimentos.

- O risco de crédito é a possibilidade da contraparte não honrar a dívida e assim o investidor não receber o valor negociado. Como no caso o devedor é o Governo Federal a chance de acontecer uma insolvência é pequena e por isso são considerados os investimentos com o menor risco de crédito.

- O risco de liquidez trata da dificuldade de ter compradores e vendedores potenciais para um determinado ativo. Quanto maior for a liquidez de um ativo, maior a facilidade de compra-lor ou de vendê-lo. Um fator determinante antes de realizar qualquer investimento é verificar a sua liquidez, pois ativos líquidos podem ser negociados sem terem o seu preço de venda afetado pela baixa demanda. Esse risco é praticamente inexistente porque o Tesouro Nacional garante a recompra dos títulos diariamente, dando assim liquidez diária.

- O risco de mercado é decorrente da variação da taxa de juros, das cotações das ações, das taxas de câmbio, do índice de inflação. Essas mudanças dos principais fatores do risco de mercado estão associadas ao cenário político 
e econômico e em alguns casos, a situações individuais. Dentro desse contexto, o risco da taxa de juros afeta muito os títulos de renda fixa, pois as mudanças nessas taxas impactam diretamente no preço dos ativos podendo causar sua desvalorização. O risco de mercado pode ser desconsiderado se os títulos comprados forem mantidos até o vencimento. Nesse caso não importam quais sejam as movimentações do mercado no meio tempo entre a compra e o vencimento, a remuneração final será exatamente a contratada na aplicação para os títulos prefixados.

Caso os títulos sejam vendidos antes do vencimento, o Tesouro Nacional pagará o seu valor de mercado, de modo que a rentabilidade poderá ser maior ou menor do que a contratada na data da compra, dependendo do preço do título no momento da venda. Isso acontece porque os preços dos títulos sofrem variações ao longo do tempo devido a alguns fatores como o nível de procura, a variação na taxa de juros da economia, a condições do mercado, as expectativas quanto ao comportamento das taxas de juros e o prazo de juros escolhido.

O preço dos títulos não evolui de forma linear, eles oscilam de acordo com a variação da taxa de juros. A relação entre a taxa de juros e o preço do título é convexa e inversamente proporcional, conforme representado no gráfico 1 . Um aumento da taxa de juros faz com que o preço do título diminua e caso a taxa de juros diminua, o preço do título aumenta.

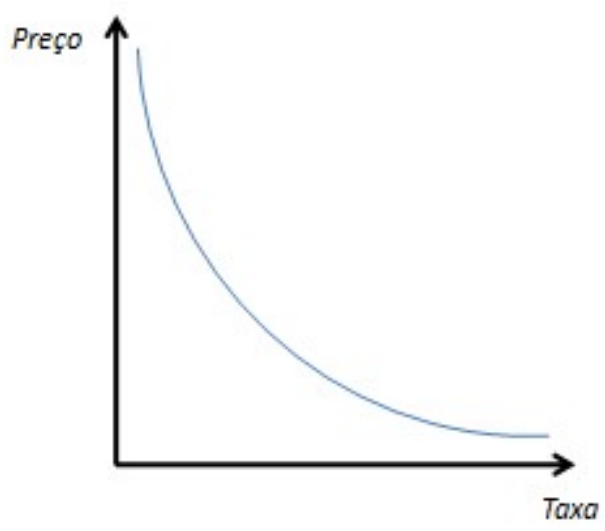

Gráfico 1: Sensibilidade do preço em função da taxa. Fonte: Elaboração própria.

Os títulos públicos são marcados a mercado e por isso o Tesouro Nacional não pode garantir que o investidor obterá ganho se vender antecipadamente. $\mathrm{O}$ 
ganho ouperda dependerá das condições de mercado na data de venda. Por isso, o retorno da carteira composta por títulos públicos em que não há a intenção de serem mantidos até o vencimento é uma variável aleatória que precisa ter seu risco controlado para evitar perdas financeiras deste portfólio.

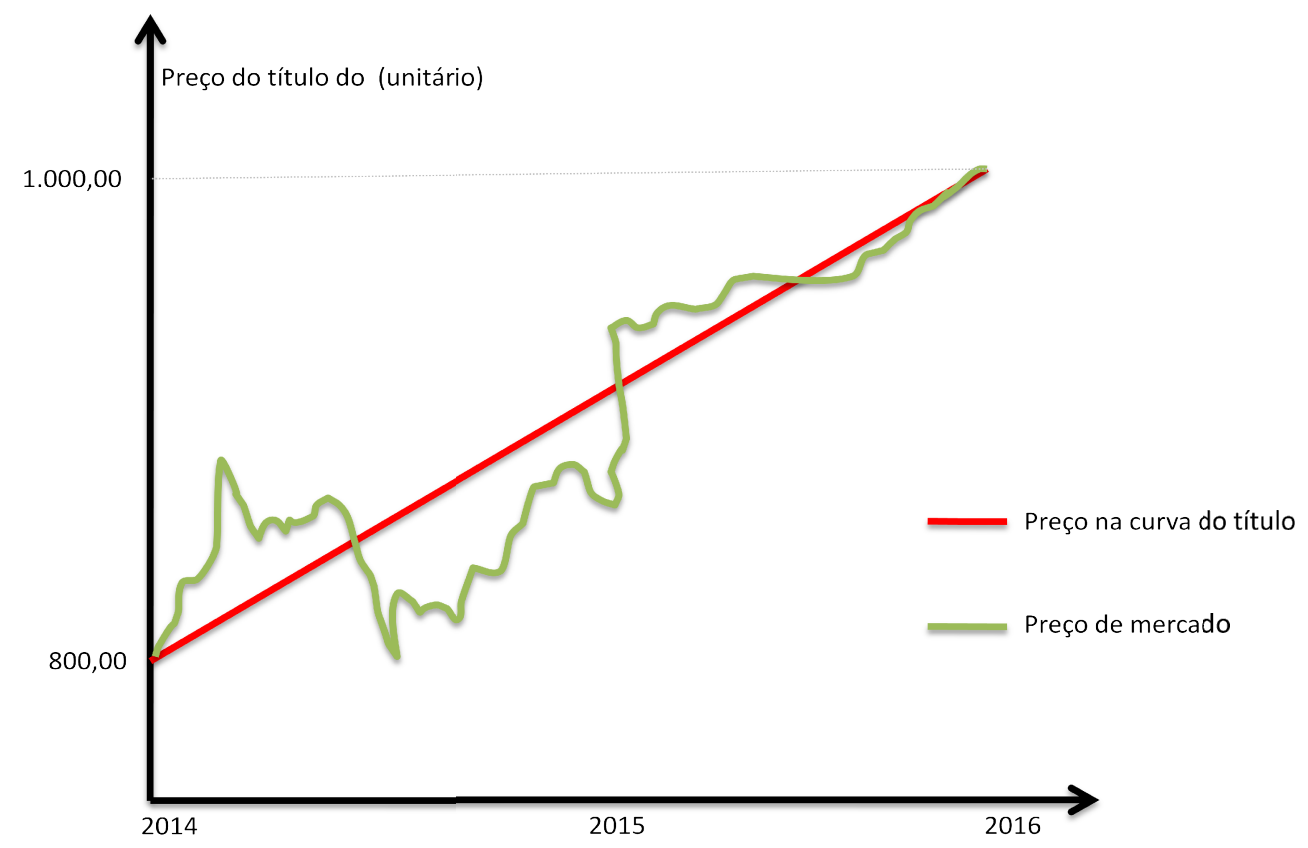

Gráfico 2: Marcação a mercado de títulos (caso LTN). Fonte: Elaboração própria.

No gráfico 2, a trajetória verde mostra a oscilação do preço do título pela marcação a mercado que varia por conta da variação nas expectativas da curva de juros futuros. Já reta vermelha representa a evolução do preço do título levado até o vencimento, de modo que a taxa acordada na compra se mantém inalterada comprovando o seu comportamento linear.

Quando a linha verde está acima da vermelha o preço de mercado é maior e vendendo nesse momento se obtém uma rentabilidade maior que a acordada na compra do título. Já quando a linha verde está abaixo da vermelha não é vantagem vender antecipadamente, pois a rentabilidade é menor do que a se esperar até o vencimento.

Ao se aproximar do vencimento ocorre a convergência do preço de mercado com o preço na curva do título independente da trajetória do mercado que aconteceu no passado.

O prazo do título também influencia na variação do seu preço, quanto maior for o prazo para o vencimento maior será o impacto causado pela variação 
da taxa de juros, porque o preço do título é o valor presente do fluxo descontado pela taxa de juros. Os títulos de prazo mais longos tendem a ser mais voláteis que os títulos de prazos mais curtos e no caso de taxas de juros baixas no mercado os títulos longos terão uma maior valorização.

Existem diferentes tipos de títulos públicos federais e eles possuem comportamentos distintos quanto à variação de mercado. São diversos títulos com prazos e rentabilidades diferentes. Dependendo do momento econômico do mercado alguns títulos podem ser mais vantajosos do que outros. A acessibilidade dos títulos públicos caracterizada pela opção de compra de frações do título e a sua diversidade de alternativas faz com que sejam um investimento interessante.

\subsubsection{1}

\section{Títulos prefixados}

Os títulos públicos prefixados têm rentabilidade definida no momento da compra se levados até o vencimento. São indicados para quando se acredita que a taxa prefixada será maior que a taxa Selic, a taxa de juros básica da economia.

Por terem rentabilidade predefinida, o rendimento desses títulos não considera o efeito da inflação sobre o valor do título, ele é nominal. Para se encontrar o rendimento real é necessário descontar a inflação. Os títulos públicos federais prefixados disponíveis para negociação são:

Tesouro Prefixado (LTN)

Possui fluxo de pagamento simples no final da aplicação, se recebe o valor investido mais a rentabilidade acordada. Para cada unidade de título, o valor bruto a ser recebido no vencimento é de $\mathrm{R} \$ 1.000,00$, conforme apresentado na figura 5 . 


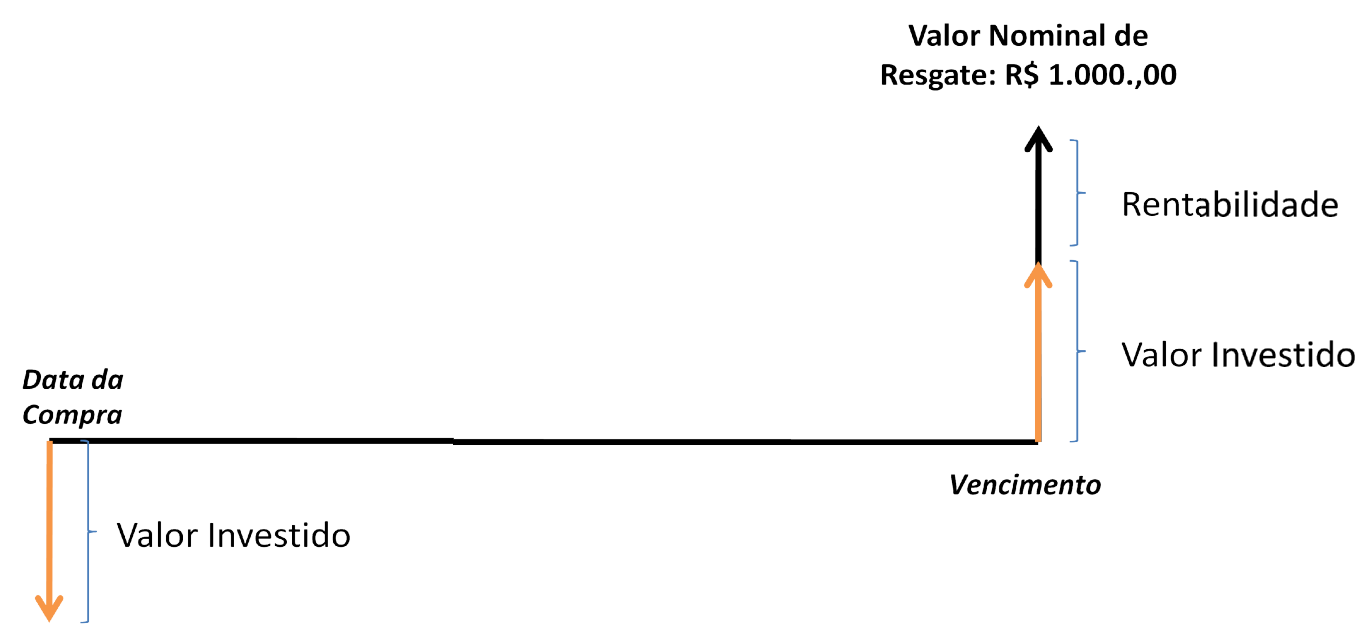

Figura 5: Fluxo de pagamentos do Tesouro Prefixado. Fonte: Elaboração própria.

Quando a rentabilidade do Tesouro Prefixado aumenta para quem já possui o título pode ser um bom momento para venda antecipada. Mas para compra a rentabilidade se tornou menor, porque o preço aumentou. Esses dois movimentos se compensam e asseguram a viabilidade de que levando o título até o vencimento a rentabilidade será a contratada no momento da compra.

As LTN são títulos simples de serem precificados. Como não há pagamente de cupom semestral, o valor presente do fluxo único (valor do vencimento) descontado pela taxa de juros é o seu preço unitário. O valor unitário no vencimento será sempre $\mathrm{R} \$ 1.000,00$, independentemente da data de emissão ou do resgate do título.

Pela equação (17) fica evidente a relação inversa do preço do título com a taxa de juros:

$$
P=\frac{1000}{(1+i)^{D U / 252}}
$$

$\mathrm{P}=$ preço do título negociado

$\mathrm{i}=$ taxa de juros efetiva ao ano em percentual

DU $=$ dias úteis entre a data de aplicação e a data de resgate (diferença entre compra e vencimento)

$\mathrm{O}$ valor $\mathrm{R} \$ 1.000,00$ foi usado considerando o valor nominal no resgate ocorrendo no vencimento. 
Tesouro Prefixado com Juros Semestrais (NTN-F)

A diferença é quanto ao pagamento de juros semestrais ao longo da aplicação. No vencimento, a última parcela é composta R $\$ 1.000,00$ mais o último pagamento dos juros semestrais.

\subsubsection{2}

\section{Títulos pós-fixados}

Os títulos pós-fixados têm seu valor corrigido por um indexador. A rentabilidade da aplicação é composta pela taxa Selic ou por uma taxa predefinida na compra do título acrescido da variação de um índice de inflação (IPCA, IGPM).Os títulos públicos federais disponíveis para negociação são:

\section{Tesouro Selic (LFT)}

O título LFT (Letras Financeiras do Tesouro) possui fluxo de pagamento simples no final da aplicação, quando se recebe o valor investido mais a rentabilidade no vencimento, conforme figura 6. A rentabilidade é pós-fixada indexada à taxa de juros da economia (Selic) por isso é indicado quando se acredita que a tendência de alta da taxa Selic.

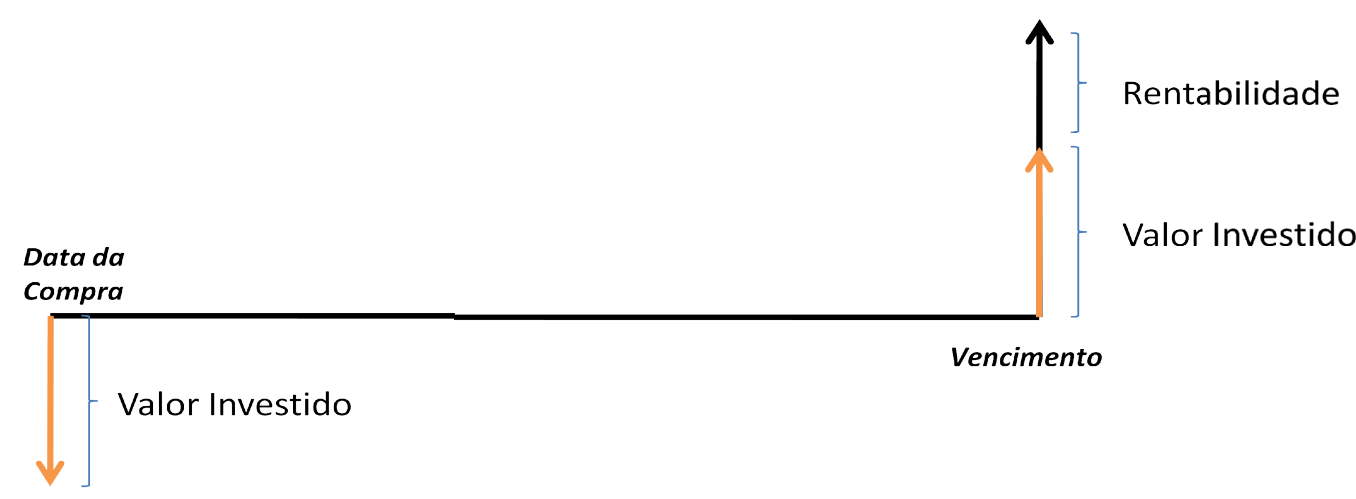

Figura 6: Fluxo de pagamentos Tesouro Selic. Fonte: Elaboração própria.

Dentre os títulos disponíveis, o Tesouro Selic tem o comportamento mais estável, sem muitas oscilações. A rentabilidade da LFT sempre acompanha a Selic no período e por isso apresenta baixa volatilidade. Assim, dificilmente ocasionam perdas financeiras em casos de venda antecipada. Esse título torna-se uma boa opção para aplicar recursos que poderão ser resgatados no curto prazo.

O comportamento típico do Tesouro Selic é estar sempre subindo, o que muda é o ritmo da subida, pois a velocidade com que o seu preço aumenta vai 
depender da variação da taxa Selic. Quando os juros sobem sua rentabilidade aumenta, ou seja, o título se valoriza mais depressa. Já quando os juros caem sua rentabilidade diminui, mas é continuamente positiva. A taxa de juros informada é nominal, porque não considera o efeito da inflação sobre o valor do título.

Isso faz com que o mercado se refira ao Tesouro Selic como o investimento livre de risco em nossa economia. Por outro lado a rentabilidade do Tesouro Selic tende a ser mais baixa que o de outros títulos, adequada para um perfil de investimento mais conservador. Quando se monta uma carteira diversificada, o Tesouro Selic é o componente usado para reduzir a incerteza proporcionada por outros ativos.

A sua negociação pode ser feita com uma taxa de deságio ou ágio divulgada no momento da compra. Essa taxa será acrescida à variação da Selic. $\mathrm{O}$ preço unitário é o valor principal acrescido da correção da Selic partir da database até a data de negociação. A data base fixada é 01/07/2000. Ou seja, o preço do tesouro Selic é atualizado diariamente pela taxa Selic efetiva do dia

O VNA (Valor Nominal Atualizado) permite calcular a variação do indexador atrelado ao título. Na data-base o VNA da LFT tinha valor de $\mathrm{R} \$ 1.000,00$ e elas são valorizadas pelo acumulado das taxas Selic percentual ao ao nominal desde essa data até seu vencimento, conforme equação (18).

$$
P=1000 \cdot \prod_{i=1}^{n}\left(1+t x \text { Selic }_{i}\right)^{\frac{1}{252}}
$$

Tesouro IPCA+ (NTN-B Principal)

Possui fluxo de pagamento simples, valor investido acrescido da rentabilidade ocorre apenas no vencimento. Seu rendimento é formado por uma taxa de juros prefixada acertada no momento da compra e acrescida a variação do IPCA, por isso pode ser considerado um título híbrido. É um investimento que concede proteção quanto à inflação e oferece rentabilidade real igual a taxa de juros prefixada contratada. 
Tesouro IPCA+ com Juros Semestrais (NTN-B)

Difere do Tesouro IPCA+ apenas pelo fluxo de pagamento ser composto por de juros semestrais.

\section{Notas do Tesouro Nacional - Série C (NTN-C)}

São títulos com rentabilidade vinculada à variação do IGP-M, acrescida de juros pactuados no momento da compra. Também possui rentabilidade real. Esse título pode se encontrar não disponível para negociação.

\section{4 \\ Modelo da curva de juros}

A taxa de juros é a variável mais significativa da economia e influencia todas as decisões financeiras e econômicas, individuais e do país. A taxa de juros é muito importante, mas não é negociada in natura. São negociados títulos de renda fixa que são atrelados a essas taxas.

A estrutura a termo da taxa de juros (ETTJ) é representada por um conjunto de pontos associados compondo a relação de taxa de juros versus maturidade (DONALD R. CHAMBERS, WILLARD T. CARLETON, 1984). E é construída a partir de dados do mercado. A ETTJ foi desenvolvida com o objetivo de criar parâmetros para precificar títulos prefixados de renda fixa sem pagamento de cupom. A taxa de juros também pode ser usada para medir a atratividade de um título, quanto maior ela for, maior será o interesse econômico no título (LUENBERGER, 1998).

A utilização de um modelo paramétrico para a estrutura a termo das taxas de juros permite estimar a curva de juros contínua que encaixe os dados de forma suave. A partir de um conjunto discreto de dados composto por taxas e prazos, pode-se construir uma curva de juros.

O formato da curva pode variar, mas o considerado padrão é positivamente inclinada, crescente e côncava. São esperadas taxas de juros mais altas para títulos de longo prazo porque elas costumam ter um prêmio de liquidez embutido para compensar o maior risco da maturidade alta. Os modelos fatoriais dinâmicos vêm sendo usados para realizar o ajuste da curva de juros aos dados capazes de descrever sua estrutura que deve ser contínua e suave. 


\subsection{1 \\ Modelo de Nelson \& Siegel (1987)}

Um dos modelos paramétricos de curvas de juros mais conhecidos é o modelo de Nelson \& Siegel. É um modelo parcimonioso que busca aproximar a curva de juros por uma soma de funções exponenciais(NELSON; SIEGEL, 1987).

Os modelos parcimoniosos apresentam em sua expressão matemática poucos fatores que obedecem a restrições e que têm representação simples. O uso de muitos parâmetros aumenta a incerteza do modelo, pois mais termos teriam que ser estimados (DIEBOLD; LI; YUE, 2008).

Esse modelo consiste em aplicar uma fórmula paramétrica para a estrutura a termo da taxa de juros continuamente composta, dada pela função exponencial das maturidades e de um conjunto de parâmetros válidos para toda a curva.

$$
y_{t}(\tau)=\beta_{0 t}+\beta_{1 t}\left(\frac{1-e^{-\lambda_{t} \tau}}{\lambda_{t} \tau}\right)+\beta_{2 t}\left(\frac{1-e^{-\lambda_{t} \tau}}{\lambda_{t} \tau}-e^{-\lambda_{t} \tau}\right)
$$

Onde:

té a data de observação da curva

$\tau$ é a maturidade da taxa

$y_{t}(\tau)$ é a taxa forward de prazo $\tau$

Fatores do modelo: $\beta_{0 t}, \beta_{1 t}, \beta_{2 t} \mathrm{e} \lambda_{t}$.

É possível determinar a taxa de juros para qualquer maturidade com os quatro parâmetros de entrada definidos, $\lambda_{t}, \beta_{0 t}, \beta_{1 t}, \beta_{2 t}$. Portanto é necessário definir os parâmetros iniciais de forma a obter uma curva bem ajustada.

Se o $\lambda$ for um termo fixo, este modelo pode ser estimado por mínimos quadrados ordinários, já que resulta em um modelo linear nos betas. Se fosse optado estimar um $\lambda$ ótimo junto com os betas do modelo ter-se-ia um modelo não linear formado pelos parâmetros (DIEBOLD; LI, 2006).

Os valores dos betas podem ser estimados por mínimos quadrados ordinários de forma a minimizar o desvio entre as taxas dos títulos observados no mercado e as taxas dos mesmos títulos resultantes pelo modelo Nelson \& Siegel. 
O $\lambda$ determina o fator de decaimento da curva. Este parâmetro é responsável por determinar o tempo em o que $\beta_{2 t}$ (curvatura) atinge o máximo no médio prazo. Valores pequenos para $\lambda$ favorecem o ajuste a longo prazo com o decaimento suave,já os valores grandes para $\lambda$ tem um decaimento rápido $\mathrm{e}$ melhor ajuste para prazo mais curto. O comportamento dos coeficientes de beta serão analisados na implementação do modelo proposto no capítulo 3. 


\section{3 \\ Modelagem proposta}

\section{1 \\ Definição do modelo}

Será proposto um modelo de otimização robusta orientado por dados para alocação de uma carteira de renda fixa que busca escolher a solução que maximize o pior caso de retorno da carteira considerando todos os cenários pertencentes ao conjunto de incerteza definido. O modelo de pior caso pode ser entendido quando no caso do pior cenário se concretizar, na pior das hipóteses terá o maior retornopossível se for usada a alocação ótima de carteira proveniente do modelo. Ou seja, a melhor escolha dentro dos valores de pior caso.

Nesse trabalho foram realizadas as etapas do fluxograma da figura 7 que retrata a dinâmica para a alocação do portfólio robusto e ao longo desse capítulo serão detalhadas. 


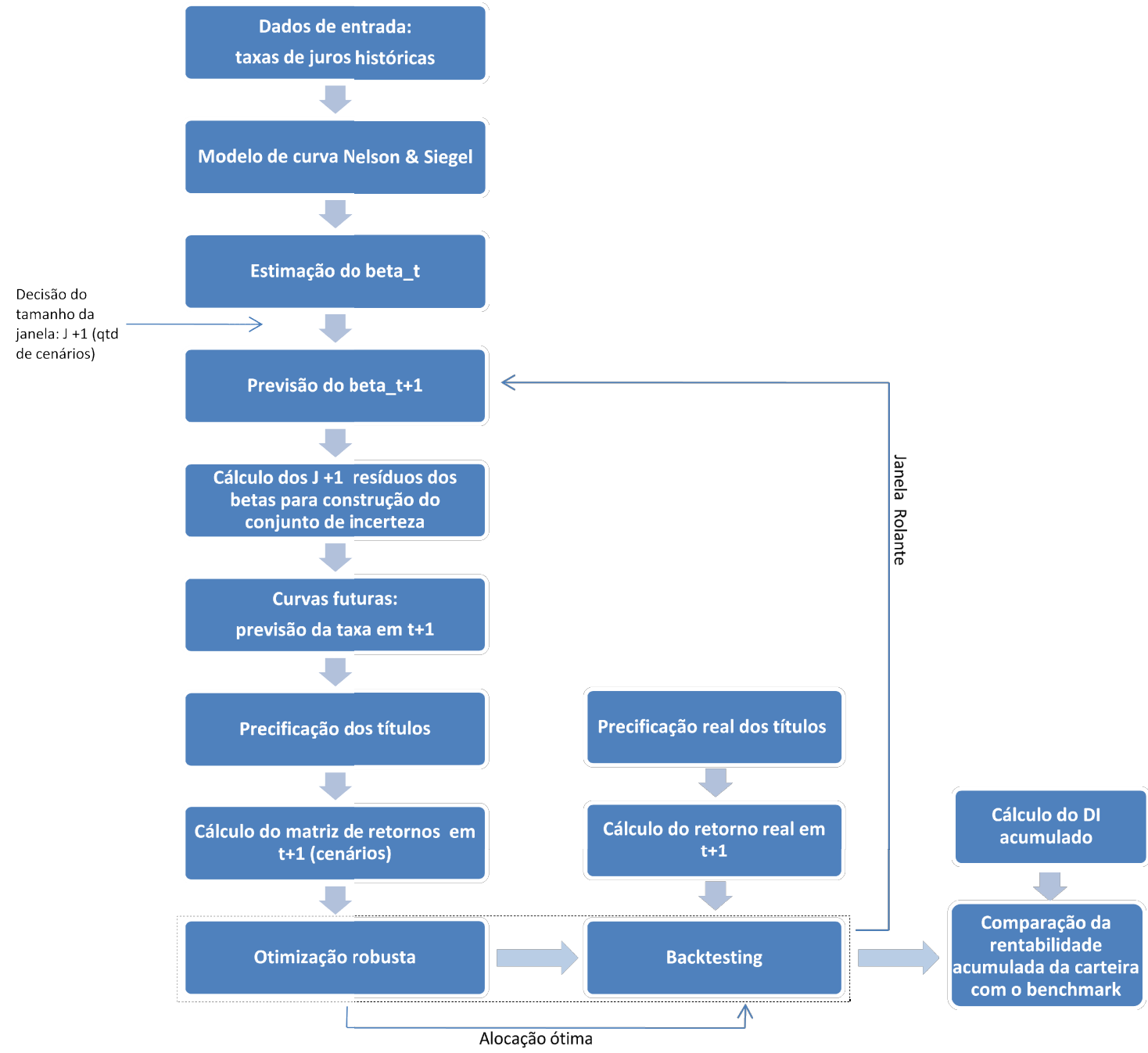

Figura 7: Fluxograma da modelagem proposta. Fonte: Elaboração própria.

\section{2}

\section{Modelo de otimização robusta}

Dessa forma foi desenvolvido um modelo de otimização robusta, o qual será apresentado pela sua função objetivo e pelas suas restrições. Em seguida serão explicados a metodologia e os cálculos realizados para alimentar esse modelo.

É proposta a construção de um portfólio ótimo que tem disponível $n$ ativos que terão alocações percentuais de forma a gerar o melhor resultado da função objetivo respeitando as restrições estabelecidas. A otimização retornará o vetor alocação $(x)$ que é a composição ótima das carteiras e o valor do retorno da carteira otimizada $(\theta)$, no nosso caso é o melhor dentre os piores casos de retorno. 
O modelo de otimização é sensível à variação dos parâmetros de entrada, por isso foram feitos vários testes comparativos com a alteração destes que terão seus resultados apresentados no próximo capítulo.

$$
\begin{array}{lll}
\max _{x, \theta} & \theta & \\
\text { s.a } & \theta \leq x^{T} . R & R \in \mathcal{U} \\
& \sum_{i=1}^{n} x_{i}=1 & \forall i \in\{1,2, \ldots, n\} \\
& x_{i} \geq 0 & \forall i \in\{1,2, \ldots, n\}
\end{array}
$$

Sendo:

$\theta=$ retorno da carteira ótima

$\mathcal{U}=$ conjunto de incerteza dos retornos dos títulos prefixados calculados diariamente

$x=$ vetor da alocação ótima para cada dia $t$

$R_{i}=$ matriz dos retornos dos ativos nos cenários criados

$i=$ representa cada ativo

$n=$ número total de ativos disponíveis

A função objetivo busca maximizar o $\theta$, uma variável que representa o retorno da carteira ótima de investimentos.

A primeira restrição estabelece que o $\theta$ será o pior cenário possível, o limite inferior de retorno. Ele estará sempre abaixo do mínimo retorno da carteira considerando os retornos individuais dos ativos compondo os cenários de incerteza. Essa restrição deve ser atendida para todo retorno pertencente ao conjunto de incerteza que define os possíveis cenários futuros.

A segunda restrição diz que a soma dos pesos dos componentes tem que ser igual a $1(100 \%)$, o que significa que todo o capital disponível terá que ser investido entre os ativos disponíveis em cada período $t$ de alocação, sem alavancagem e sem sobras.

A terceira restrição não é permitida a venda a descoberto, que é a venda de um ativo sem possuí-lo. Isso é representado pela expressão onde são proibidos percentuais de alocação negativa para os ativos. 
Respeitando a região viável é obtida a melhor solução que satisfaz a formulação da função objetivo. Todos os cenários são incorporados simultaneamente no nosso problema de otimização e é desejada a solução admissível para todos eles conjuntamente.

\section{3}

\section{Entradas para o modelo: Taxa PRE DI}

Nesse trabalho foram usadas as taxas pré-fixadas implícitas em contratos de swap PRExDI para um conjunto de prazos em dias úteis negociados na Bolsa de Mercadorias e Futuros (BM\&FBOVESPA).

O swap PRE $\times$ DI é o contrato em que as contrapartes trocam indexadores. Envolve a troca de posições de um fluxo de caixa indexado à taxa prefixada (fixa) por um fluxo indexado à taxa DI (flutuante). A troca de indexadores de operações ativas e passivas não troca o principal.

\section{4}

\section{Interpolação flat forward}

Para alguns casos dentro da amostra extraída foi necessário interpolar para encontrar as taxas de vértices não disponibilizadas pela fonte dos dados (Bloomberg). O método utilizado foi a interpolação flat forward,ou seja, primeiro é realizado o cálculo da taxa forward e depois o cálculo da taxa intercalada no prazo desejado.

Devido ao grande número de instrumentos financeiros existentes só estão disponíveis as taxas de juros para determinados prazos. Para definir a taxa dos prazos intermediários é necessário interpolar com o método adequado que vai possibilitar calcular as taxas de juros para os vencimentos que estejam entre os vértices existentes.

O método de interpolação da estrutura a termo da taxa de juros com precificação muito utilizado é o flat forward. A interpolação flat forward considera que a taxa forward entre dois vértices conhecidos é constante. Sua metodologia funciona de modo similar a uma progressão geométrica entre dois vértices interpolando pelo prazo de dias úteis. 
Temos para o prazo $d u_{1}$ o vértice com a taxa $P_{1}$ e para o prazo $d u_{2}$ o vértice a com taxa $P_{2}$ e desejamos obter a taxa $P_{*}$ para o prazo $d u_{*}$, sendo $d u_{1}<d u_{*}<$ $d u_{2}$.Sendo $F_{12}$ a taxa forward entre os prazos $d_{1}$ e du $u_{2}$, então temos:

$$
\left(1+F_{12}\right)^{\frac{d u_{2}-d u_{1}}{252}}=\frac{\left(1+P_{2}\right)^{\frac{d u_{2}}{252}}}{\left(1+P_{1}\right)^{\frac{d u_{1}}{252}}}
$$

Pela condição de interpolação flat forward, a taxa forward entre $\mathrm{du}_{1} \mathrm{e} \mathrm{du}_{2}$ é constante e com isso $\mathrm{F}_{12}=F w d$. Logo a taxa $\mathrm{P} *$ será tal que:

$$
\begin{aligned}
& \left(1+P_{*}\right)^{\frac{d u_{*}}{252}}=\left(1+P_{1}\right)^{\frac{d u_{1}}{252}} \times(1+F W d)^{\frac{d u_{*}-d u_{1}}{252}} \\
& P_{*}=\left[\left(1+P_{1}\right)^{\frac{d u_{1}}{252}} \times(1+F w d)^{\frac{d u_{*}-d u_{1}}{252}}\right]^{\frac{252}{d u_{*}}}-1
\end{aligned}
$$

Graficamente podemos representar:

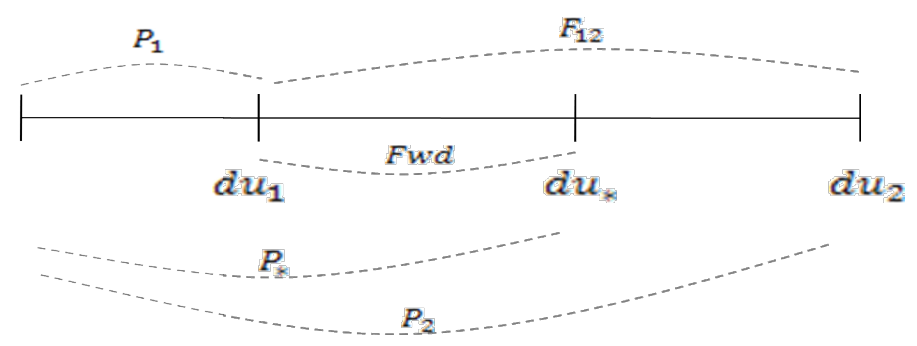

Figura 8: Representação da Interpolação Flat Forward. Fonte: Elaboração própria.

$\mathrm{P}_{*}=$ Taxa de juros pré do vencimento desejado

$\mathrm{P}_{1}=$ Taxa de juros pré do vértice anterior ao vencimento desejado

$\mathrm{P}_{2}=$ Taxa de juros pré do vértice posterior ao vencimento desejado

$d^{*}=$ Número de dias úteis até o vencimento desejado

$\mathrm{du}_{1}=$ Número de dias úteis até o vértice anterior ao vencimento desejado $\mathrm{du}_{2}=$ Número de dias úteis até o vértice posterior ao vencimento desejado A taxa Fwd é a taxa de juros expressa com base 252 dias úteis. 


\section{5}

Previsão da curva de Juros

Os títulos prefixados vendidos antes do vencimento têm o seu preço de mercado governado diariamente pela ETTJ, por isso o risco associado a um título de renda fixa é referente às variações das taxas de juros associadas a cada uma das suas maturidades. Dependendo do movimento das taxas e da composição da carteira pode-se obter resultados com lucro ou com perda. A metodologia usada para a construção da estrutura a termo da taxa de juros é o modelo de Nelson \& Siegel, descrito no capítulo 2.

\subsection{1}

\section{Parâmetros da curva}

O parâmetro $\lambda_{t}$ foi considerado constante, determinado de forma empírica. Para chegar ao valor de $\lambda_{t}$ foram feitas calibrações de forma que o $\lambda_{t}$ escolhido fizesse com que a maturidade média fosse o ponto máximo na curvatura do $\beta_{2 t}$. O prazo de 36 meses foi considerada a maturidade média.

A equação (19) de Nelson \& Siegel foi utilizada para os ajustes da curva. Com as equações (24), (25) e (26) foi possível compor a matriz de coeficientes dos betas. Foi formada uma matriz de coeficientes, para cada uma das 26 maturidades foram calculados os três coeficientes dos betas.

$$
\text { Coef. Beta } a_{0}=1
$$

$$
\text { Coef. Beta } 1=\left(\frac{1-e^{-\lambda_{t} \tau}}{\lambda_{t} \tau}\right)
$$

$$
\text { Coef. Beta } 2=\left(\frac{1-e^{-\lambda_{t} \tau}}{\lambda_{t} \tau}-e^{-\lambda_{t} \tau}\right)
$$




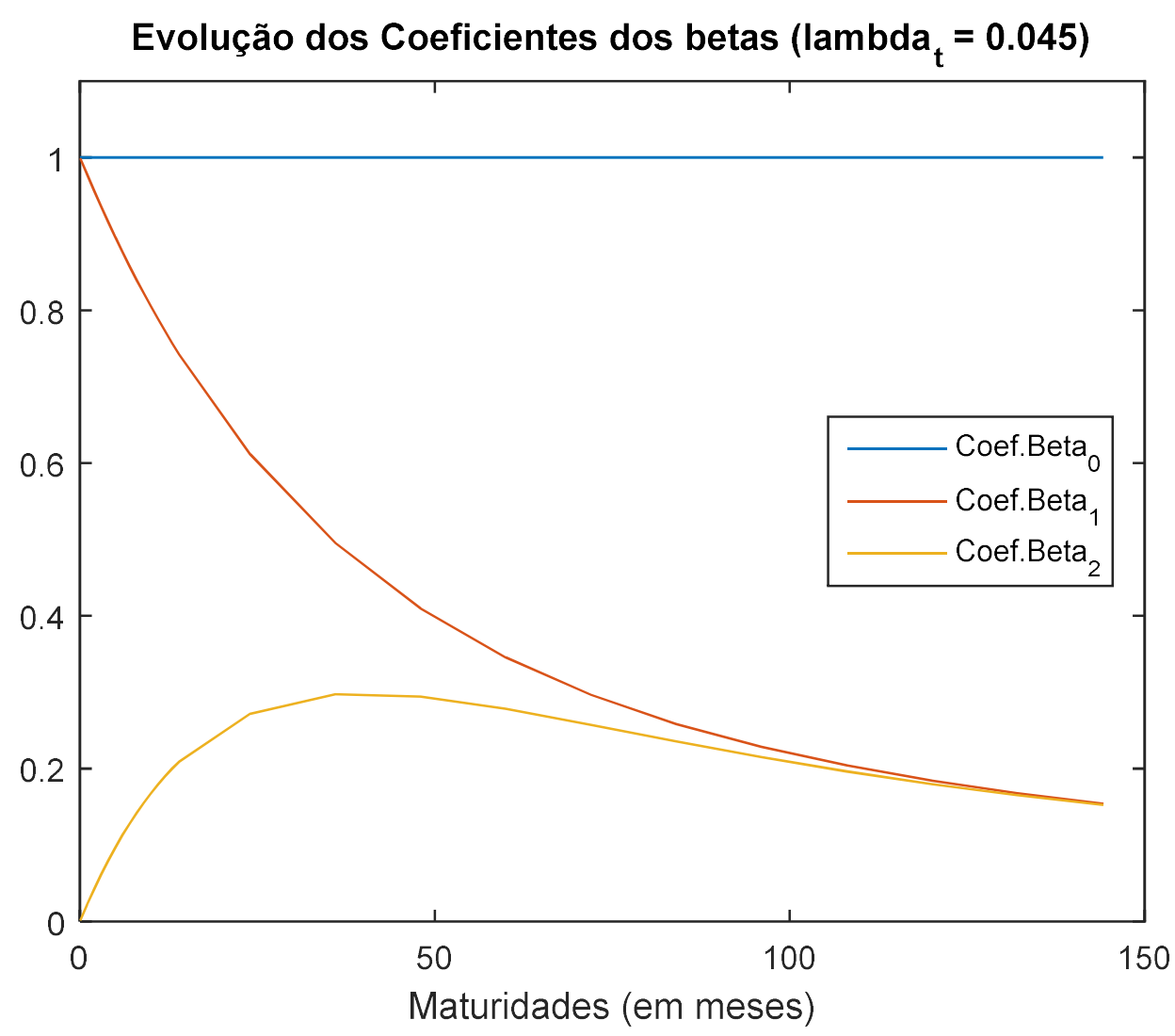

Figura 9: Evolução dos coeficientes dos betas. Fonte: Elaboração própria.

A evolução dos coeficientes dos betas é apresentada na figura 9. O coeficiente de $\beta_{0 t}$ é constante igual a 1 para todas as maturidades. $\mathrm{O}$ valor do $\beta_{0 t}$ impacta diretamente no nível da ETTJ (se positivo deslocamento paralelo para cima e se negativo deslocamento paralelo para baixo) e é o parâmetro de longo prazo da curva.

O coeficiente de $\beta_{1 t}$ apresenta um comportamento monotonicamente decrescente de 1 a 0 com o aumento da maturidade. $\mathrm{O}$ valor do $\beta_{1 t}$ impacta na inclinação da ETTJ, pois as taxas curtas são afetadas por um fator maior do que o aplicado nas taxas longas. É o parâmetro de curto prazo da curva.

O coeficiente de $\beta_{2 t}$ apresenta uma corcova, começando no zero crescendo até assumir valores positivos, alcança seu máximo e depois decai em direção ao zero. $\mathrm{O}$ valor de $\beta_{2 t}$ impacta na curvatura da ETTJ e é o parâmetro de médio prazo da curva. 


\subsection{2 \\ Estimação dos betas}

Com os coeficientes dos betas já calculados e com as taxas históricas observadas, tem-se uma expressão linear e podem-se calcular os betas por meio de uma regressão. Os parâmetros foram estimados no MATLAB por meio de mínimos quadrados ordinários sendo utilizada a função lsqlin que tem como objetivo a minimização dos erros da regressão, a soma dos quadrados da diferença entre os valores estimados e os observados. O lsqlin produz um resultado que minimiza a violação de restrição de pior caso e resolve problemas de ajuste de curva de mínimos.Após achar a estimativa dos betas para cada dia a função é dependente apenas das maturidades para estimar as taxas de juros correspondentes a essa maturidade. Teremos um vetor com uma taxa estimada para cada maturidade que irá compor a curva da taxa de juros para cada dia.

\section{6}

\section{Construção do conjunto de incertezas}

A teoria do portfólio considera a rentabilidade do ativo como uma variável aleatória e um portfólio têm seu retorno ponderado pelo retorno dos ativos que a compõe. O risco é o desvio do retorno, ou seja, a probabilidade de o retorno não ser o esperado. Por meio da diversificação é possível diluir o risco e aumentar a potencialidade do retorno.

O retorno do portfólio é dado pela relação linear entre os pesos e os retornos individuais de cada ativo, ou seja, a média ponderada dos retornos esperados individuais:

$$
R_{p}=x_{1} R_{1}+x_{2} R_{2}+\cdots+x_{n} R_{n}=\sum_{i=1}^{n} x_{i} R_{i}=x^{T} R
$$

O vetor alocação $x=\left[x_{1}, x_{2}, \ldots, x_{n-1}, x_{n}\right]$, onde $x_{i}$ é o percentual do total de recursos alocados em cada ativo $i . O$ vetor aleatório de retornos individuais é $R=\left[R_{1}, R_{2}, \ldots, R_{n-1}, R_{n}\right]$

A composição da carteira de investimentos será de um ativo livre de risco e mais $n-1$ ativos com risco $m$ maturidades diferentes. $\mathrm{O}$ ativo livre de risco 
será o título pós-fixado selic e os ativos com risco serão os títulos prefixados nominal de curto, médio ou longo prazo. Com a inclusão do ativo livre de risco o retorno da carteira será:

$$
R_{p}=x_{1} A+x_{2} R_{2}+\cdots+x_{n} R_{n}
$$

sendo A o retorno certo do ativo livre de risco.

O desenvolvimento desse estudo empírico contém títulos públicos com diferentes maturidades para obter um portfólio ótimo e terá seu desempenho comparado ao índice de mercado. Para ser realizada a seleção ótima das carteiras robustas de renda fixa, selecionamos da base de dados utilizada diversas maturidades de títulos públicos condizentes com a realidade de venda de títulos pelo Tesouro Nacional.

Os títulos prefixados serão LTN que são títulos zero cupom e terãomarcação a mercado, um comportamento especulativo. E o título pós-fixado será a LFT que é indexada à Selic, por isso é sem risco de perdas e não tem especulação. Como dados de entrada será extraída da Cetip a taxa Selic 1 dia, em dias úteis para toda nossa série de observações analisada.Será usada como taxa curta, o retorno de 1 dia.

A inclusão do ativo livre de risco, representado pela Selic, tem propósito de controlar o nível de risco do portfólio. A posição em um título pós-fixado atrelado à Selic auxilia na redução da exposição em cenários em que o mercado não está favorável para os investimentos porque ele não sofre oscilação negativa de preços do mercado.

Conclui-se que um investimento atrelado à Selic precisa estar disponível para dar consistência às carteiras otimizadas e diversificadas. Os títulos indexados a Selic sempre irão apresentar resultados positivos, mesmo quando em períodos de crise e alta volatilidade. Em períodos de alta da taxa de juros os títulos prefixados e os títulos indexados à inflação podem ter rentabilidade negativa.

A alocação ótima de ativos para o portfólio é feita sob condições de incerteza quanto aos retornos futuros. Foi elaborada uma metodologia para a estimação de cenários representativos desses retornos futuros estimados. Para construir um portfólio de renda fixa baseado no retorno dos ativos precisa-se da curva de juros para realizar a marcação a mercado e a precificação dos títulos. 
Conforme já descrito, com as taxas de juros de entrada $(\widehat{t x})$ foi feita a modelagem da curva de juros, a partir do cálculo dos coeficientes dos betas e da estimação dos betas, pela qual foram calculadas as taxas estimadas do período.

$$
\begin{gathered}
\ln (1+\widehat{t x})=\hat{y} \\
\widehat{t x}=e^{\hat{y}}-1
\end{gathered}
$$

A otimização robusta incorpora a otimização sob incerteza em situações práticas como a gestão de carteiras. A carteira robusta será obtida pela otimização de pior caso, mas o conjunto de incertezas que farão parte do modelo será proveniente de modelos de estimação tradicionais. As incertezas serão estimadas e tratadas como cenários compondo um conjunto delimitado e convexo, a solução ótima será um dos vértices. Nese contexto, uma explicação simples do que consiste a otimização robusta de pior caso é que ela garante que em caso de concretizado o pior cenário possível que a alocação ótima terá um desempenho superior a qualquer outra alocação possível.

A otimização robusta do pior caso pode em alguns casos obter soluções subótimas se comparado a outros modelos mais otimistas principalmente em períodos de grande volatilidade. Mas apresenta a vantagem de proporcionar confiabilidade e retornos consistentes mesmo quando há uma expressiva incerteza nos cenários, e muito dos outros modelos pecam nessas ocasiões.

O uso de cenários representa a incerteza do comportamento do mercado. Não é possível prever a taxa futura, mas é viável trabalhar com cenários distintos que retratam um evento incerto e estabelecem limites de possibilidades. As incertezas são incorporadas pelos preços dos títulos de renda fixa prefixados que variam no tempo pela marcação a mercado, mas tem seu valor final a longo prazo (vencimento) estabelecido. Ao contrário, é o comportamento do título pós-fixado, que tem estabilidade na sua evolução, mas o seu valor final a longo prazo não é de conhecido previamente.

O conjunto de incertezas criado determinará a região de confiança do modelo para os retornos dos títulos prefixados. Quanto maior for a janela de cenários, maior o número de restrições e portanto como consequência menor a região de confiança. 
Usando os betas estimados já calculados se inicia a previsão dos cenários, nosso conjunto de incerteza, pelo cálculo das previsões do beta um dia a frente é dado por:

$$
B_{t+1}=\hat{\beta}_{t}+\varepsilon
$$

Os resíduos dos betas são usados para simular a previsão do beta de amanhã e será calculada uma série de resíduos $(\mathrm{J}+1)$ baseada na janela escolhida de t-J até t. $\mathrm{O}$ tamanho da janela será $\mathrm{J}+1$. A definição do número de cenários é feita pelo tamanho da janela do cálculo dos resíduos, sendo J e t dados de entrada do modelo. O t é o dia de análise e chamaremos de $\mathrm{J}$ o período de tempo variável do passado (número de dias úteis para trás) que será usado para a previsão.

$$
\varepsilon=\hat{\beta}_{t-J}-\hat{\beta}_{t-J-1}
$$

O tamanho dessa janela de estimação é o número de resíduos de cada beta que será o tamanho da série dos betas estimados em $\mathrm{t}+1$ e que por fim será o número de estimações da taxa em $\mathrm{t}+1$. Estas serão usadas pra precificar os títulos e prever um passo a frente dos retornos. Assim, o J será o parâmetro de conservadorismo do modelo.

A previsão da taxa de amanhã será estimada e com isso tem-se uma taxa para cada cenário, em cada maturidade, em $\mathrm{t}+1$. A simulação é repetida para cada cenário e serão calculados os valores para cada um deles.

$$
\begin{gathered}
{\left[\begin{array}{c}
\hat{y}_{t+1}\left(\tau_{1}\right) \\
\hat{y}_{t+1}\left(\tau_{2}\right) \\
\vdots \\
\hat{y}_{t+1}\left(\tau_{N}\right)
\end{array}\right]=\left[\begin{array}{ccc}
1 & \frac{1-e^{-\lambda_{t} \tau_{1}}}{\lambda_{t} \tau_{1}} & \frac{1-e^{-\lambda_{t} \tau_{1}}}{\lambda_{t} \tau_{1}}-e^{-\lambda_{t} \tau_{1}} \\
1 & \frac{1-e^{-\lambda_{t} \tau_{2}}}{\lambda_{t} \tau_{2}} & \frac{1-e^{-\lambda_{t} \tau_{2}}}{\lambda_{t} \tau_{2}}-e^{-\lambda_{t} \tau_{2}} \\
\vdots & \vdots \\
\vdots & \frac{1-e^{-\lambda_{t} \tau_{N}}}{\lambda_{t} \tau_{N}} & \frac{1-e^{-\lambda_{t} \tau_{N}}}{\lambda_{t} \tau_{N}}-e^{-\lambda_{t} \tau_{N}}
\end{array}\right] \cdot\left[\begin{array}{l}
B_{0, t+1} \\
B_{1, t+1} \\
B_{2, t+1}
\end{array}\right]} \\
\hat{y}_{t+1}(\tau)=B_{0, t+1}+B_{1, t+1}\left(\frac{1-e^{-\lambda_{t} \tau}}{\lambda_{t} \tau}\right)+B_{2, t+1}\left(\frac{1-e^{-\lambda_{t} \tau}}{\lambda_{t} \tau}-e^{-\lambda_{t} \tau}\right)
\end{gathered}
$$




$$
\widehat{t x}_{t+1, M}=e^{\hat{y}_{t+1, M}}-1
$$

Por consequência tem-se um preço $\left(\hat{P}_{t+1}\right)$ associado a cada taxa e, portanto tem-se um retorno $\left(\hat{R}_{t+1}\right)$ associado a cada preço. Segue abaixo o cálculo do retorno:

$$
\begin{gathered}
\hat{R}_{t+1, i}=\frac{\hat{P}_{t+1, i}}{\hat{P}_{t, i}}-1 \\
\hat{R}_{t+1, i}=\frac{\frac{1}{\left(1+\widehat{t x}_{t+1, M-1}\right)^{M-1}}}{\frac{1}{\left(1+\operatorname{taxa}_{t, M}\right)^{M}}}-1 \\
\hat{R}_{t+1, i}=\frac{\left(1+\operatorname{taxa}_{t, M}\right)^{M}}{\left(1+\widehat{t x}_{t+1, M-1}\right)^{M-1}}-1
\end{gathered}
$$

$i=$ representa cada ativo

$t=$ determinado dia

$\widehat{R}_{t+1, i}=$ retorno estimado do ativo $i$ em $t+1$

$\widehat{P}_{t+1, i}=$ preço estimado do ativo $i$ em $t+1$

$\widehat{P}_{t, i}=$ preço estimado do ativo $i$ em $t$

$M=$ maturidade

taxa = taxa real observada

$\widehat{t x}=$ taxa estimada pelo modelo da curva de juros

A distribuição logarítmica foi usada para garantir a consistência evitando a ocorrência de preços negativos, e os retornos serão compostos de forma contínua.

$\mathrm{O} \mathrm{R}_{\mathrm{t}+1}$ é o retorno entre o tempo $\mathrm{t}$ e $\mathrm{t}+1$. $E \widehat{\mathrm{R}}_{\mathrm{t}+1}$ é a previsão do retorno estimado entre $\mathrm{t}$ e $\mathrm{t}+1$, que é calculado como já descrito anteriormente com as informações disponíveis antes de $\mathrm{t}$, ou seja, dados passados à data de referência. 
Os retornos foram calculados baseados em dados e são a base do modelo de otimização sendo o conjunto poliédrico de incerteza do modelo.

Por fim, são selecionados apenas os retornos do meu conjunto de ativos (maturidades das minhas LTN), e é incluído o retorno da taxa curta (LFT indexado à Selic). Com isso, todos os dados necessários para a simulação do modelo de otimização estão disponíveis, os retornos calculados formaram a matriz de retornos, os cenários, que são os dados de entrada que compõe o conjunto de incerteza para o modelo de otimização.

O mecanismo de implementação usado consistiu em pegar um ponto do horizonte de tempo e definir como data de análise, usando como dados de entrada do modelo apenas os dados anteriores a essa data. Depois os resultados obtidos na otimização são testados em períodos a frente da data de análise, cujos dados também estão disponíveis. Através do backtesting é esperado concluir que as alocações do modelo apresentem condições para as aplicações futuras compatíveis com as previstas na otimização.

$\mathrm{Na}$ análise do período rolante, o tamanho do horizonte é dado de entrada e o conjunto incerto dos dados vai sendo atualizados a cada dia com o movimento da janela rolante. Essa abordagem captura de forma dinâmica o modelo no tempo.

Para a realização do backtesting considera-se que o retorno real é a composição da alocação do modelo baseado nos retornos previstos, mas no caso são usados os retornos que realmente aconteceram para calcular o retorno real da carteira. Com isso é possível analisar se a alocação foi de fato boa, mas esse retorno só é conhecido depois de o fato ocorrer.

$$
R p_{r}=x^{\prime} . R_{r}
$$

Sendo:

$R p_{r}=$ retorno real da carteira para determinado dia $t$

$x=$ vetor da alocação ótima para cada dia $\mathrm{t}$

$R_{r}=$ vetor do retorno real dos ativos para determinado dia $t$ 


\section{4}

\section{Análise empírica dos resultados}

Serão apresentados os resultados das simulações computacionais. Os estudos empíricos realizados incluem as análises de sensibilidade da quantidade de cenários, do dia de análise, do tamanho da janela rolante e do horizonte de implementação, sempre com as considerações adequadas para cada resultado. Também serão feitas análises de backtesting, a simulação de um fundo de investimento com rentabilidade comparadaao benchmark adequado e o cálculo do índice Sharpe como apoio à tomada decisão de estratégias.

\section{1 \\ Dados de entrada}

Para implementar a metodologia foi utilizado o software MATLAB, ferramenta de simulação computacional, em todo o desenvolvimento dos algoritmos desse estudo. O MATLAB integra a análise numérica, o cálculo com matrizes, o processamento de dados e a construção de gráficos.

A base de dados escolhida para a curva de taxas de juros prefixada é formada pelas taxas referenciais PRE x DI da BM\&F extraídas da Bloomberg (BM\&F PRE x DI índex). Essa taxa é anual com base de 252 dias úteis.

A amostra contém observações dos dias úteis compreendendo período de 17/02/2014 à 12/04/2016, compondo um total de 535 observações. As séries temporais são série de observações diárias que fornecem uma visão do comportamento ao longo do tempo.

A construção da ETTJ tem como base as taxas praticadas nas operações de swap PRE x DI. Inicialmente foram usadas as taxas de juros com 26 maturidades em meses: 0,033333333 (1dia); $1 ; 2 ; 3 ; 4 ; 5 ; 6 ; 7 ; 8 ; 9 ; 10 ; 11 ; 12$; $13 ; 14 ; 24 ; 36 ; 48 ; 60 ; 72 ; 84 ; 96 ; 108 ; 120 ; 132 ; 144$. 
Os dados de entrada do modelo são um matriz (26x535) com as observações da Taxa PRE x DI de cada uma das 26 maturidade em um período de 535 dias e uma matriz (26x1) com as 26 maturidades.

\section{2}

\section{Resultados}

\subsection{1}

\section{Estimação dos valores dos betas}

A matriz das taxas observadas foi utilizada para estimar os betas de cada dia. Resultou em uma série de 3 betas estimados por dia da observação que permite compor uma curva de juros por dia. Ofator $\lambda_{t}$ usado foi 0,0450 .

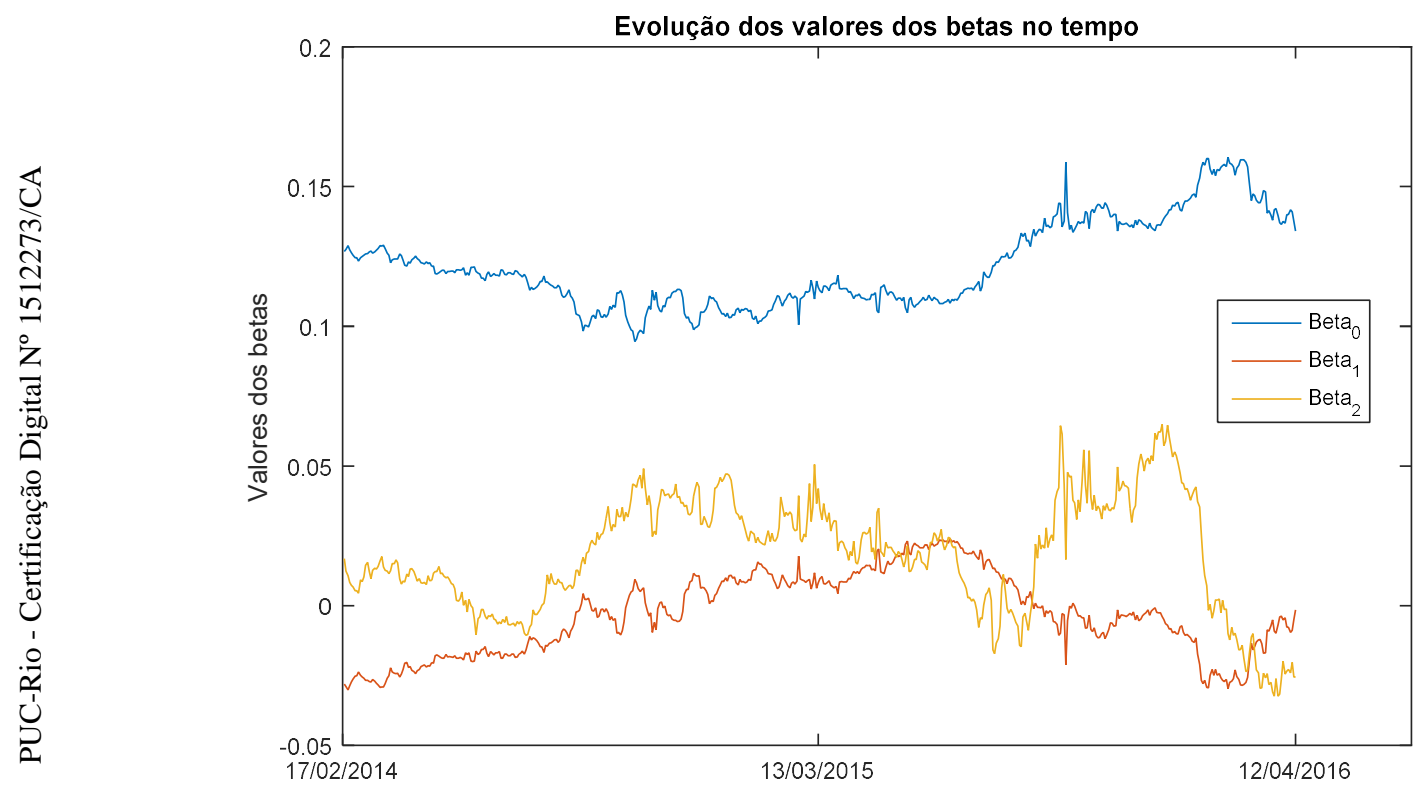

Figura 10: Evolução dos betas no tempo. Fonte: Elaboração própria.

A figura 10 da série temporal dos fatores betas mostra a evolução dos valores de beta no tempo. Em resumo os fatores $\beta_{0 t}, \beta_{1 t}, \beta_{2 t}$ representam o comportamento da curva de juros em termos de: nível, inclinação e curvatura, respectivamente variando no tempo (Diebold $\&$ Li 2006). Os valores de $\beta_{0 t}$ são sempre positivos e as taxas de longo prazo dependem exclusivamente desse beta, enquanto as taxas de curto prazo dependem do $\beta_{1 t}$ e do $\beta_{2 t}$. 


\subsection{2}

\section{Evolução das taxas de juros por maturidades no tempo}

As figuras (11) e (12) retratam a evolução das taxas observadas e estimadas, respectivamente, por maturidade no tempo apresentam comportamento similar. As curvas de diferentes prazos geralmente se movimentam juntas conforme esperado e algumas maturidades apresentaram um comportamento mais disperso enquanto outras são mais autocorrelacionadas.

Evolução das taxas dos títulos usadas no modelo de otimização no tempo

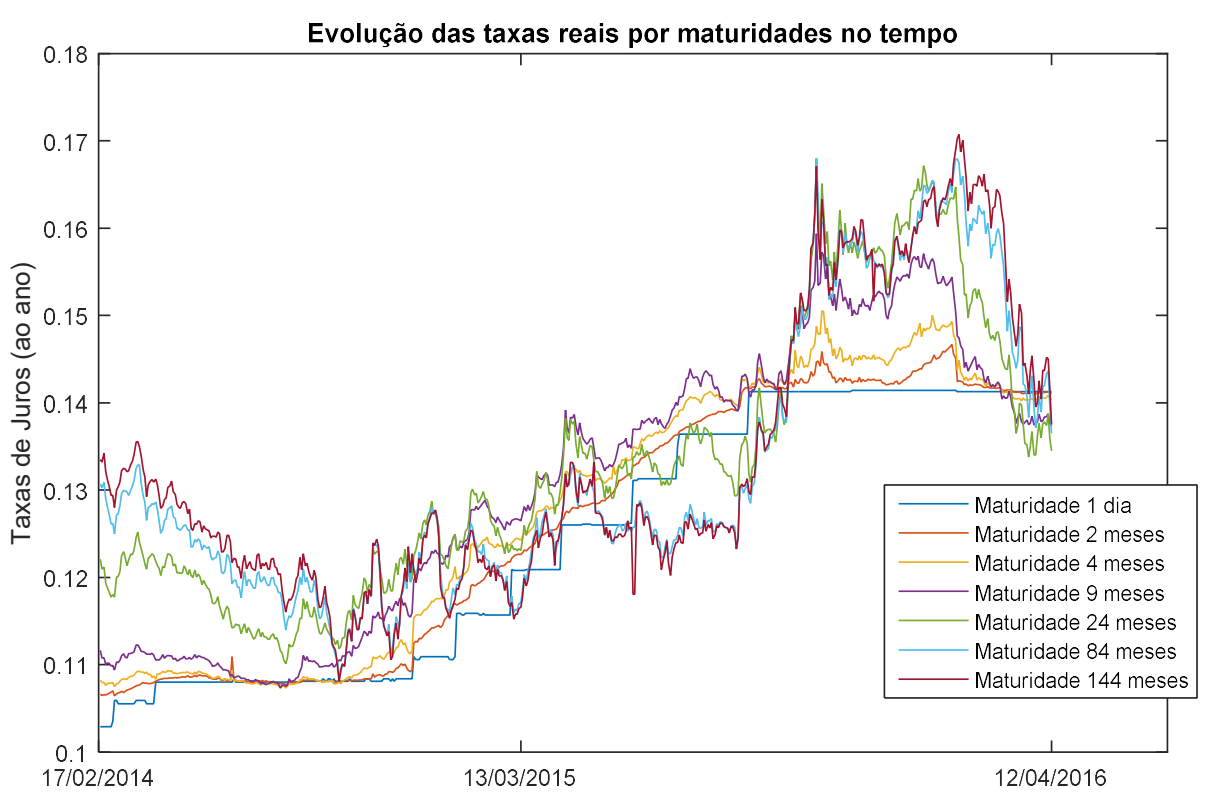

Figura 11: Evolução das taxas extraídas da Bloomberg por maturidades no tempo. Fonte: Elaboração própria. 


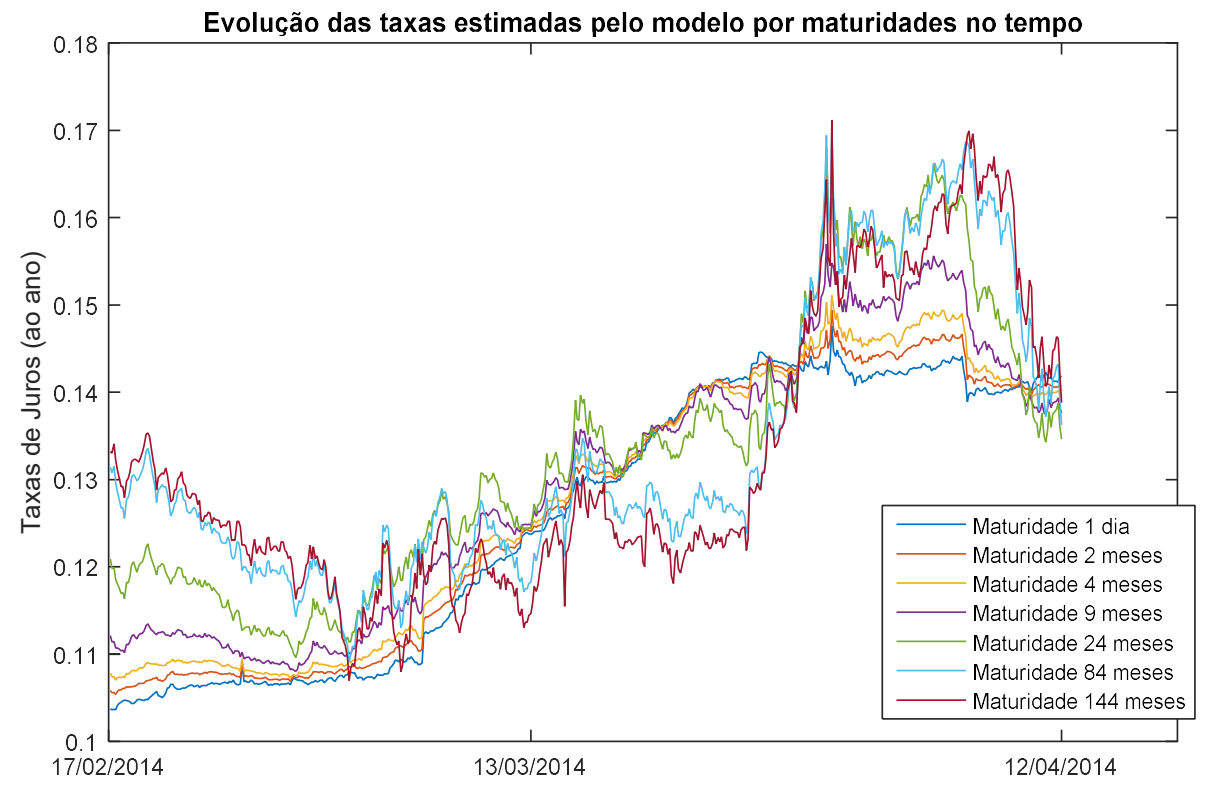

Figura 12: Evolução das taxas calculadas pelo modelo por maturidades no tempo. Fonte: Elaboração própria.

\subsection{3 \\ Curvas de juros estimadas e curva de juros real}

A ETTJ nominal foi estimada diariamente para todo o período. São 535 curvas de juros estimadas, uma para cada dia. Os formatos das curvas Nelson \& Siegel encontradas foram monotonicamente crescentes, monotonicamente decrescentes e com corcovas. Semelhante ao que pode ser encontrado nas curvas reais do mercado financeiro, mostrando que o modelo se adapta à realidade. As curvas estimadas tiveram o tratamento do modelo de ajuste e tem um comportamento mais suave e contínuo. 


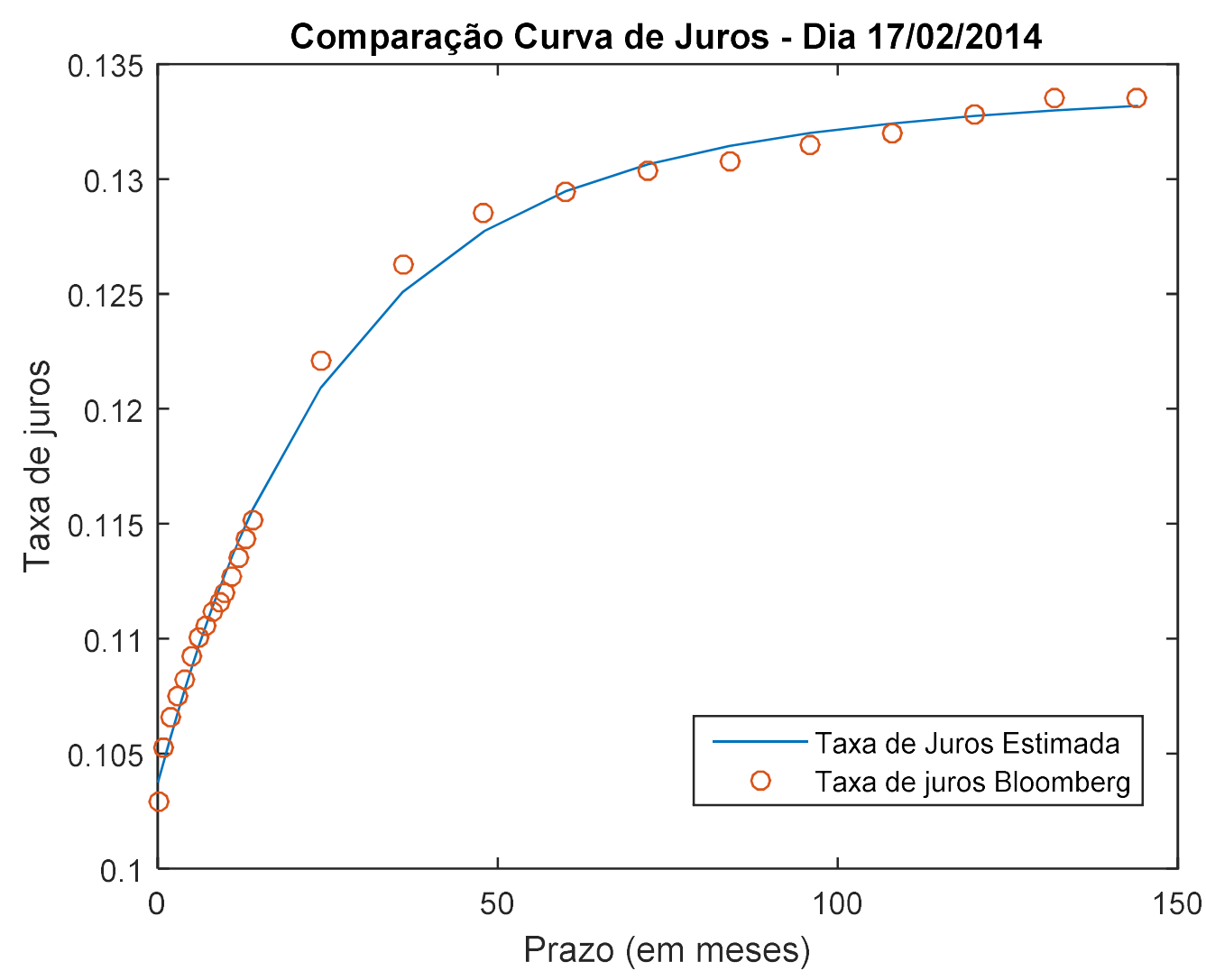

Gráfico 3: Comparação da curva de juros de dados observados com a curva de juros estimada. Fonte: Elaboração própria.

No gráfico 3, as taxas estimadas têm a mesma trajetória da curva das taxas reais, portanto o modelo usado para a previsão da curva se mostrou satisfatório. A curva Nelson \& Siegel com lambda determinístico adaptou-se às taxas observadas.

Observe que para esse dia a curva tem o formato padrão. A curva de juros clássica tem a taxa de juros para maturidades curtas menores que a taxa de juros para maturidades longas.

Serão exibidos outros formatos de curva, ainda mantendo a comparação entre as taxas reais e as estimadas pelo modelo. Foram escolhidas datas relevantes para mostrar que o panorama político e econômico do país influencia na taxa de juros. Em épocas de crise o comportamento clássico da curva dificilmente é observado. 
a) Vésperas da votação doimpeachment na câmara dos deputados $(12 / 04 / 2016)$

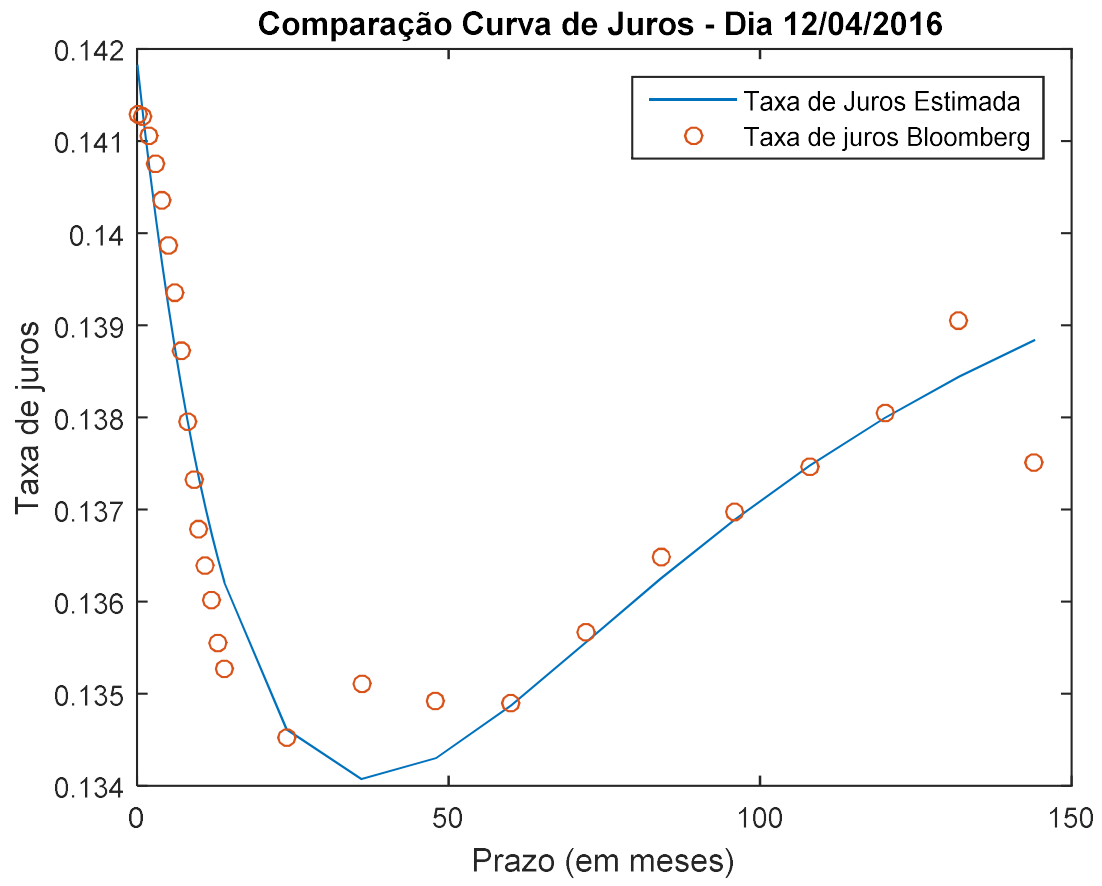

Gráfico 4: Comparação curva de juros - dia 12/04/2016. Fonte: Elaboração própria.

b) Dia que foi aprovado o pedido do impeachment (02/12/2015)

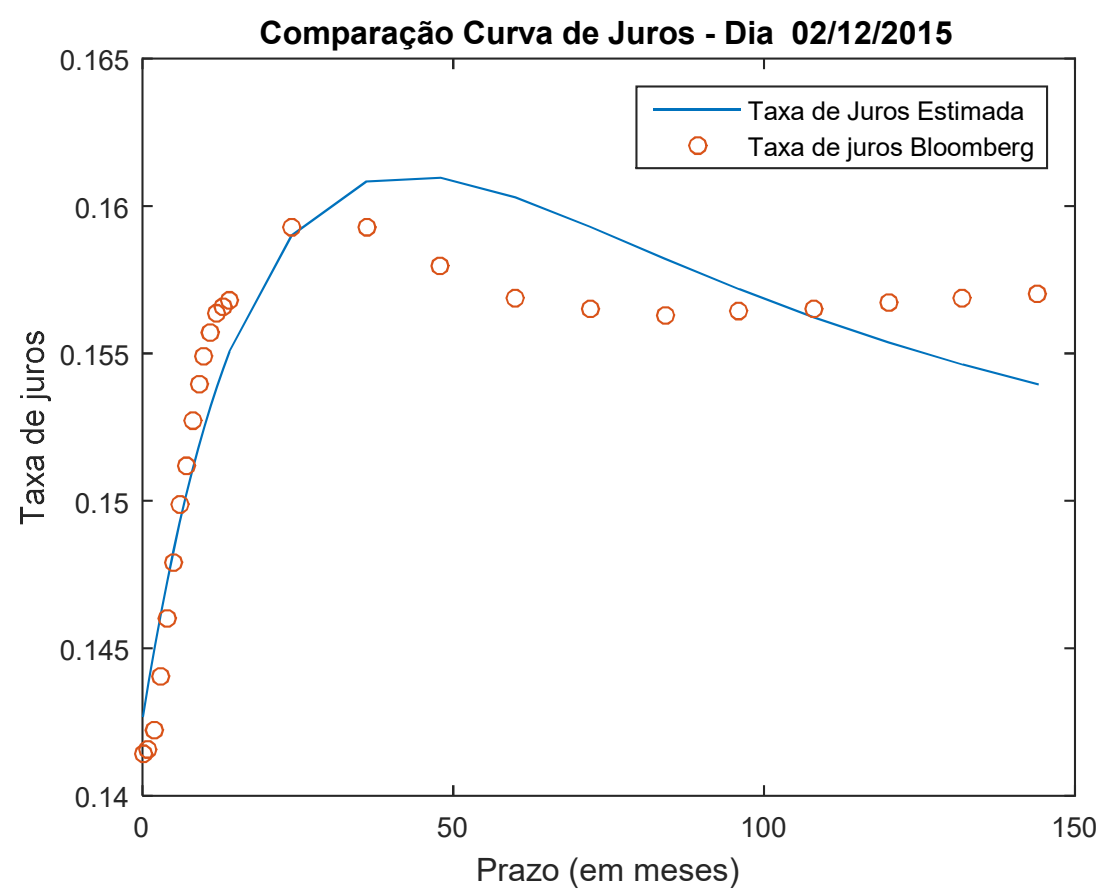

Gráfico 5: Comparação curva de juros - dia 02/12/2015. Fonte: Elaboração própria. 
c) Um dia após a reeleição de Dilma (27/10/2014)

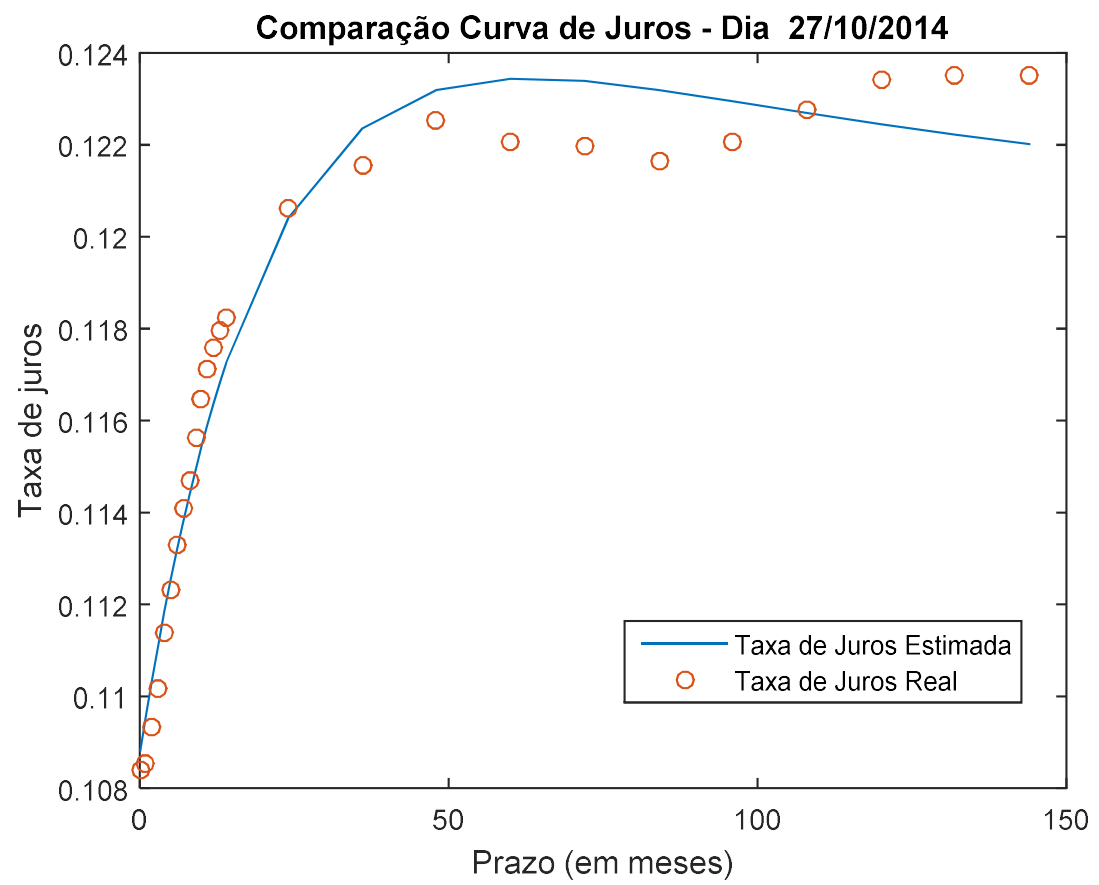

Gráfico 6: Comparação curva de juros - dia 02/12/2015. Fonte: Elaboração própria.

d) Dia seguinte ao protesto que levou $2 \mathrm{M}$ às ruas $(15 / 03 / 2015)$

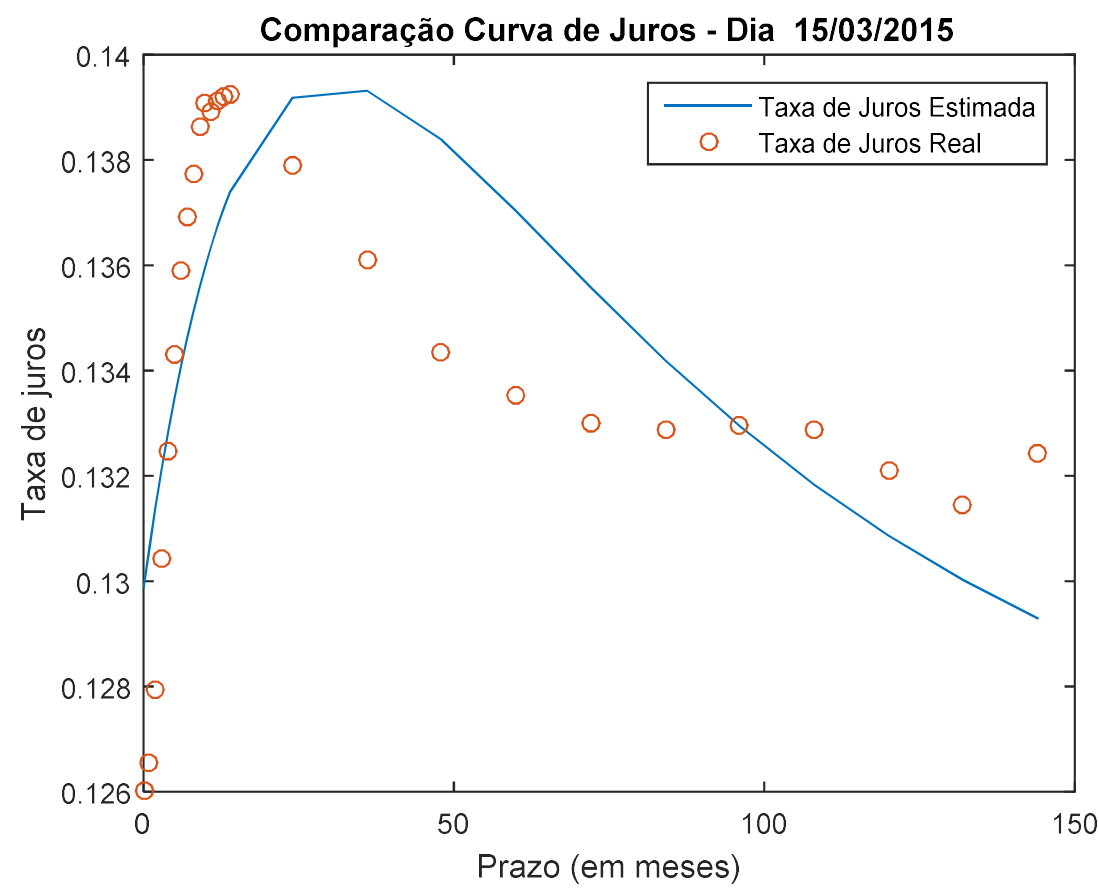

Gráfico 7: Comparação curva de juros - dia 15/03/2015. Fonte: Elaboração própria. 
e) Lava Jato - Renúncia presidente PETR e outros diretores (04/02/2015)

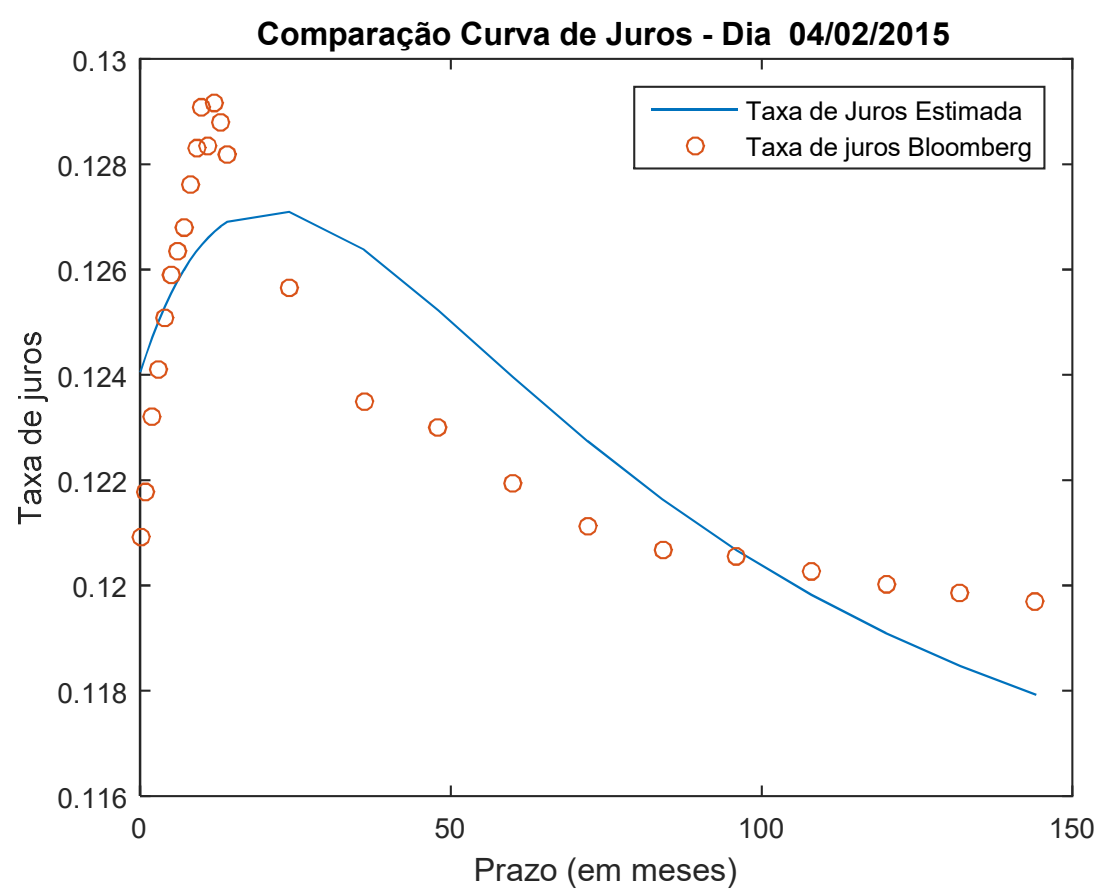

Gráfico 8: Comparação curva de juros - dia 04/02/2015. Fonte: Elaboração própria.

\section{3 \\ Resultados da otimização}

Para um modelo com 21 cenários, aplicados no dia 120 da base (12/08/2014) e tendo como títulos disponíveis o ativo livre de risco (Tesouro Selic) e os títulos prefixados com maturidades de 2 meses, 4 meses, 11 meses, 24 meses, 84 meses e 144 meses.

Executando a programação, a alocação é toda no ativo livre de risco, o pós-fixado do modelo.

$\mathrm{X}=[1,0,0,0,0,0,0]$

O retorno ótimo da carteira ( $\theta$ ) é 0,000410634997024317 . E o retorno previsto da carteira (média dos retornos previstos com a alocação ótima) é 0,000410635001578412 . Com isso o desvio (retorno previsto da carteira $-\theta$ ) será $4,55409435206125 \mathrm{e}-12$. O retorno previsto da carteira vai ser sempre maior que o $\theta$, porque o $\theta$ é o pior retorno e o outro é a média dos retornos de todos os cenários. Assim o desvio será sempre positivo. 
Foi calculado o retorno a partir da precificação dos títulos usando as taxas observadas na realidade. Esse retorno real será usado para a validação da alocação ótima do modelo de otimização.

O retorno real da carteira (retorno real calculado com a alocação dada pelo modelo é 0,000410635001731410 . A diferença entre o retorno real da carteira e o $\theta$ é 4,70709300530448e-12. Com esses resultados pode-se concluir que o modelo de previsão foi bom e a carteira real conseguiu ter um resultado compatível com o estimado.

\subsection{1}

\section{Análise do retorno de cada ativo}

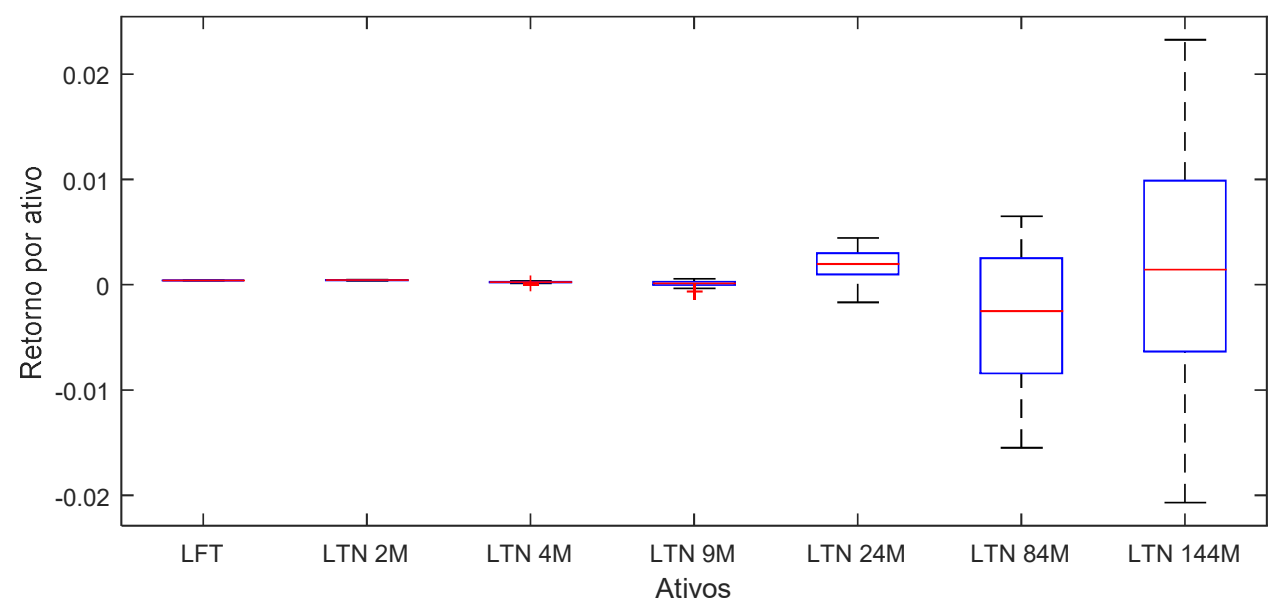

Figura 13: Variabilidade do retorno dos ativos. Fonte: Elaboração própria.

Quanto maior for a maturidade maior será a dispersão dos retornos, pois sua exposição a mudanças é maior, conforme observado na figura 13. Pequenas alterações na taxa resultam em grandes impactos nos títulos com longa maturidade, já os títulos de curto prazo são pouco afetados. Com o aumento da maturidadetambém se aumentaa sensibilidade, a inclinação e o risco.

No gráfico 9 da curva de juros desse dia com as taxas reais e as previsões para o mesmo dia através dos cenários criados mostra que as taxas de juros observadas estão dentro das estimações, mostrando um comportamento bem realista. 


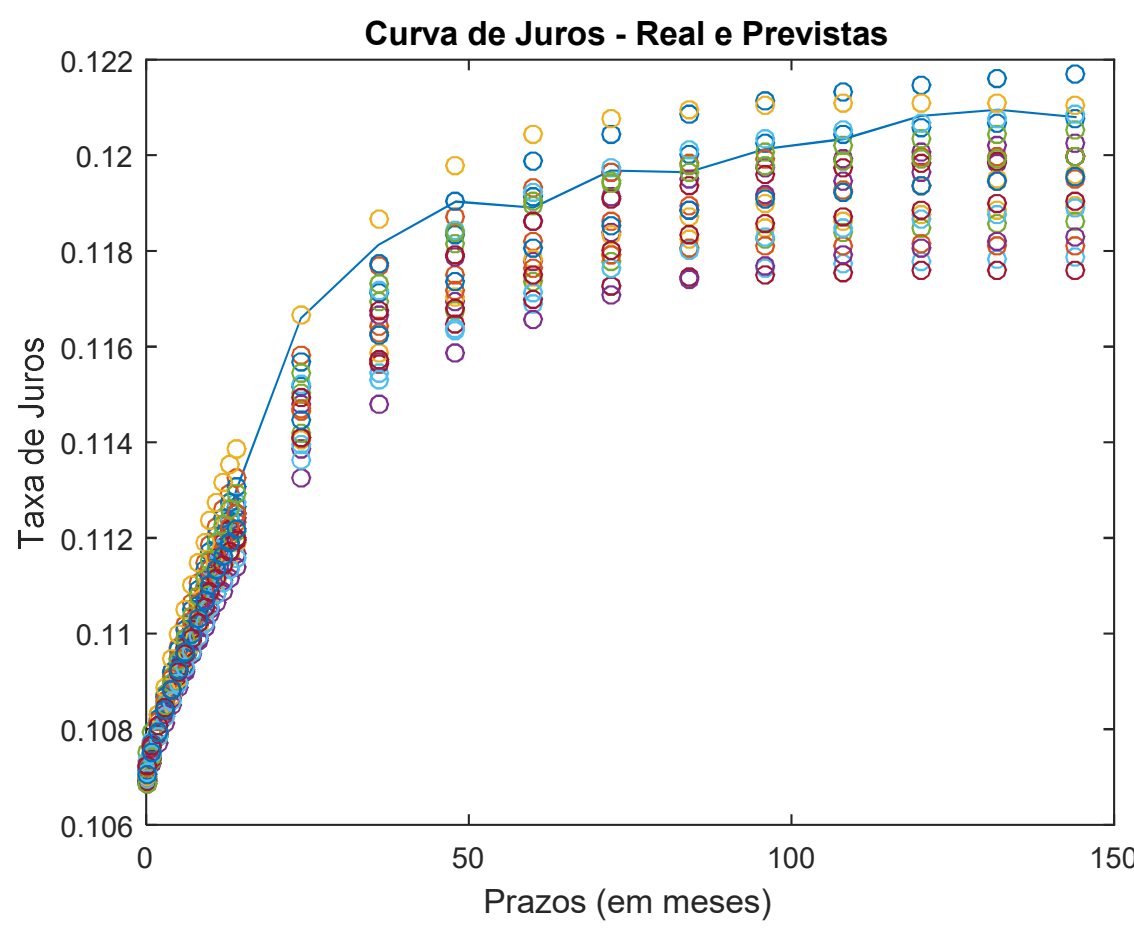

Gráfico 9: Curva de juros e previsões das curvas. Fonte: Elaboração Própria

Um modelo de otimização deve estar adequado para prever cenários financeiros pessimistas, otimistas e realistas. Esses cenários são baseados na observação de vários dias do período de previsão em análise e não de calibragem dos parâmetros do modelo. Foram ilustrados abaixo todos os casos, que mostram que o modelo está bem desenhado e sem tendência.

Com os mesmos títulos disponíveis e o mesmo número de cenários, mudando apenas o dia de análise apresenta-se um caso, gráfico 10 , onde as previsões das taxas dos cenáriossão todas localizadas abaixo da taxa real. O cenário pessimista tem as taxas reais maiores que as previsões e impossibilitam que seja feita uma alocação maximizando o retorno. 


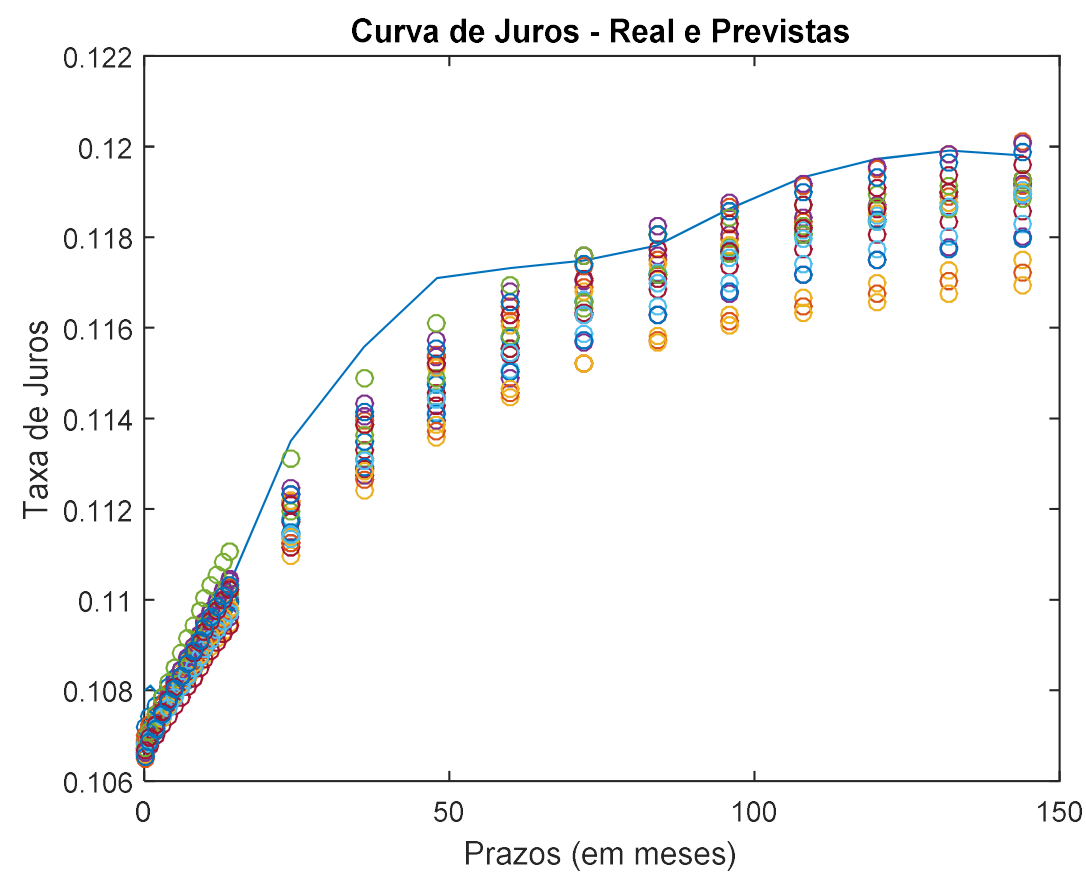

Gráfico 10: Curva de juros e previsões das curvas - Pessimista. Fonte: Elaboração Própria

Com os mesmos títulos disponíveis e o mesmo número de cenários, mudando apenas o dia de análise apresenta-se um caso onde as previsões das taxas dos cenários são praticamente todas localizadas acima da taxa real, gráfico 11. O cenário otimista tem as taxas reais menores que as previsões e pode ocorrer de realizar alocações esperando um retorno que não será compatível com a realidade.

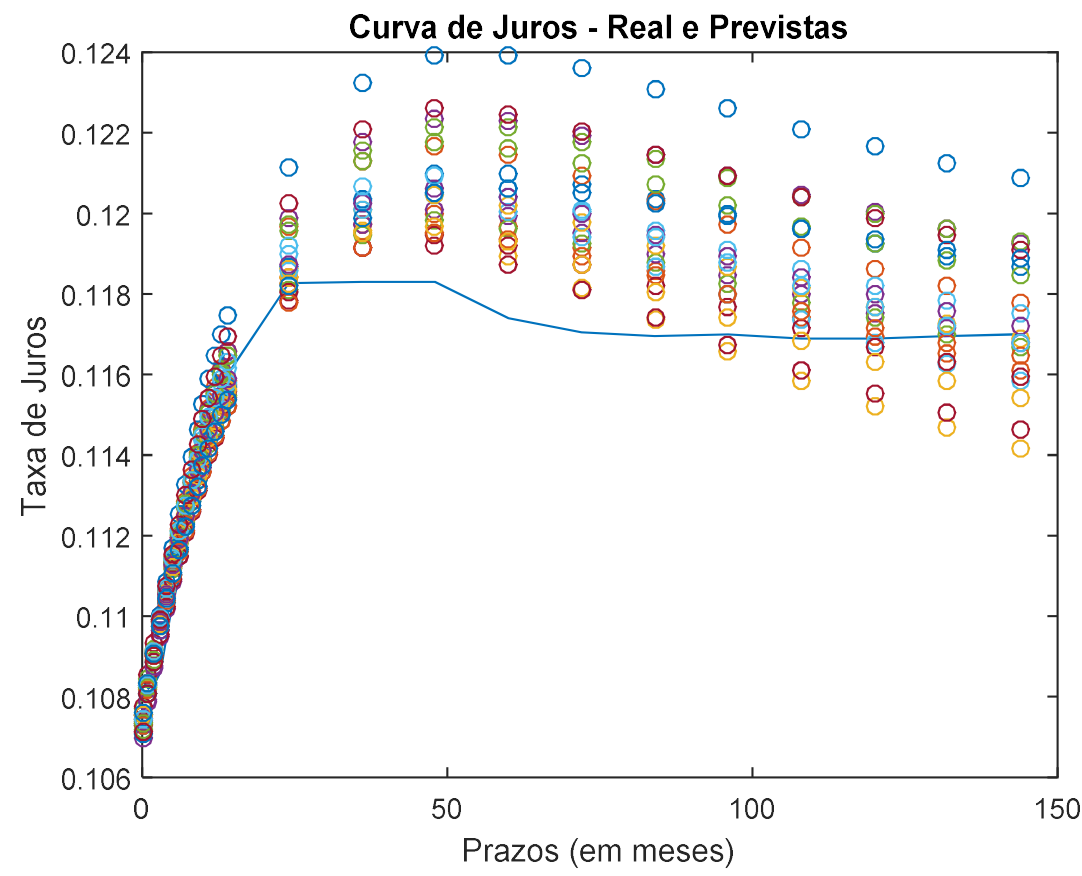

Gráfico 11: Curva de juros e previsões das curvas - Otimista. Fonte: Elaboração Própria 
Escolhendo um novo dia, encontrou-se um caso onde os cenários das taxas são muito realistas, estão agrupados tendo a curva real sendo uma média das previsões, gráfico 12. É provável que a alocação desse dia será feita com base em um retorno que corresponderá à realidade.

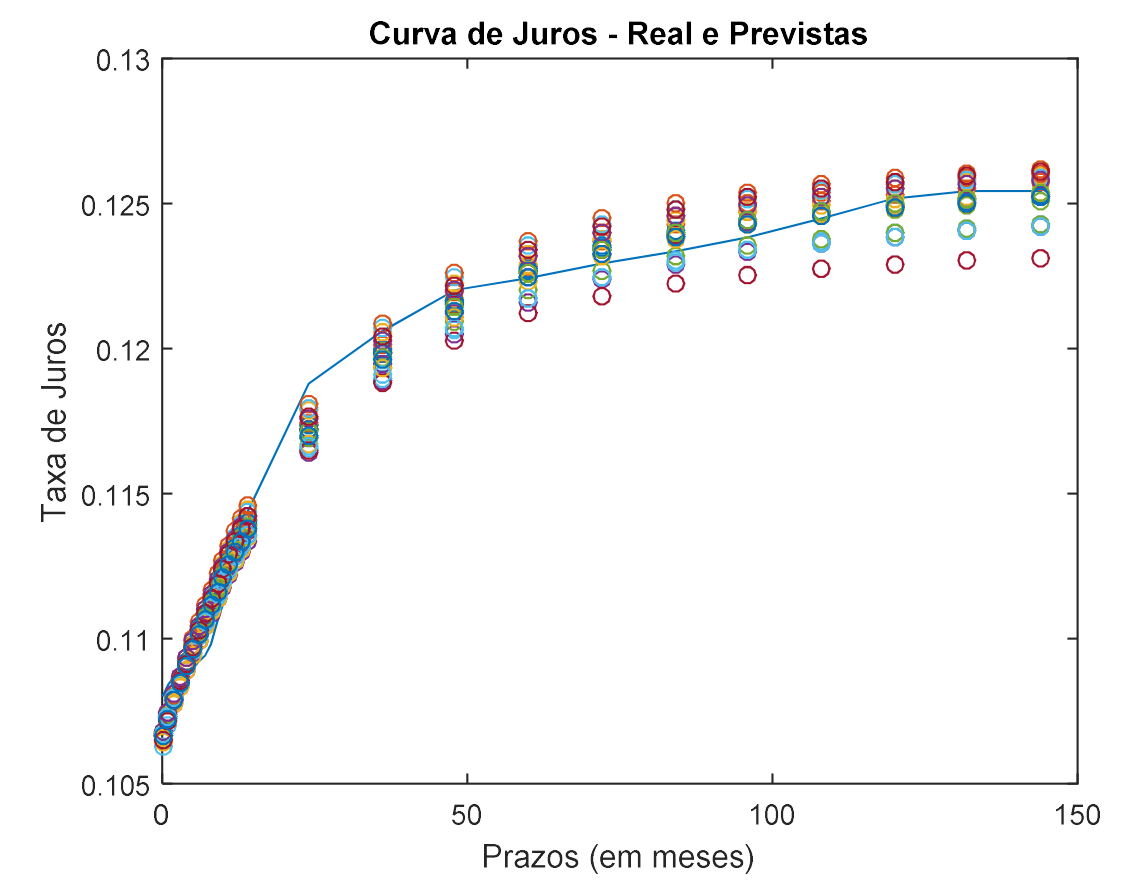

Gráfico 12: Curva de juros e previsões das curvas - Realista. Fonte: Elaboração Própria

\subsection{2 \\ Sensibilidade do retorno pela quantidade de cenários}

Para testar como o desempenho da modelagem é afetado pelo número de cenários usados, foi adotado o procedimento de variar o tamanho das janelas de geração de cenários. A decisão do tamanho da janela é um parâmetro de conservadorismo ao risco que retrata o comportamento do investidor quando exposto à incertezas.

Um número grande de cenários determina um comportamento conservador, pois aumenta o número de observações que traduzem as possibilidades de concretização dos retornos dos ativos, nesse caso a alocação provável é o ativo livre de risco, que é o título pós-fixado. E um número reduzido de cenários determina um comportamento mais arriscado onde a alocação provável é em um ativo com risco, que são os títulos prefixados. 
Boxplot - para cada quantidade de cenários
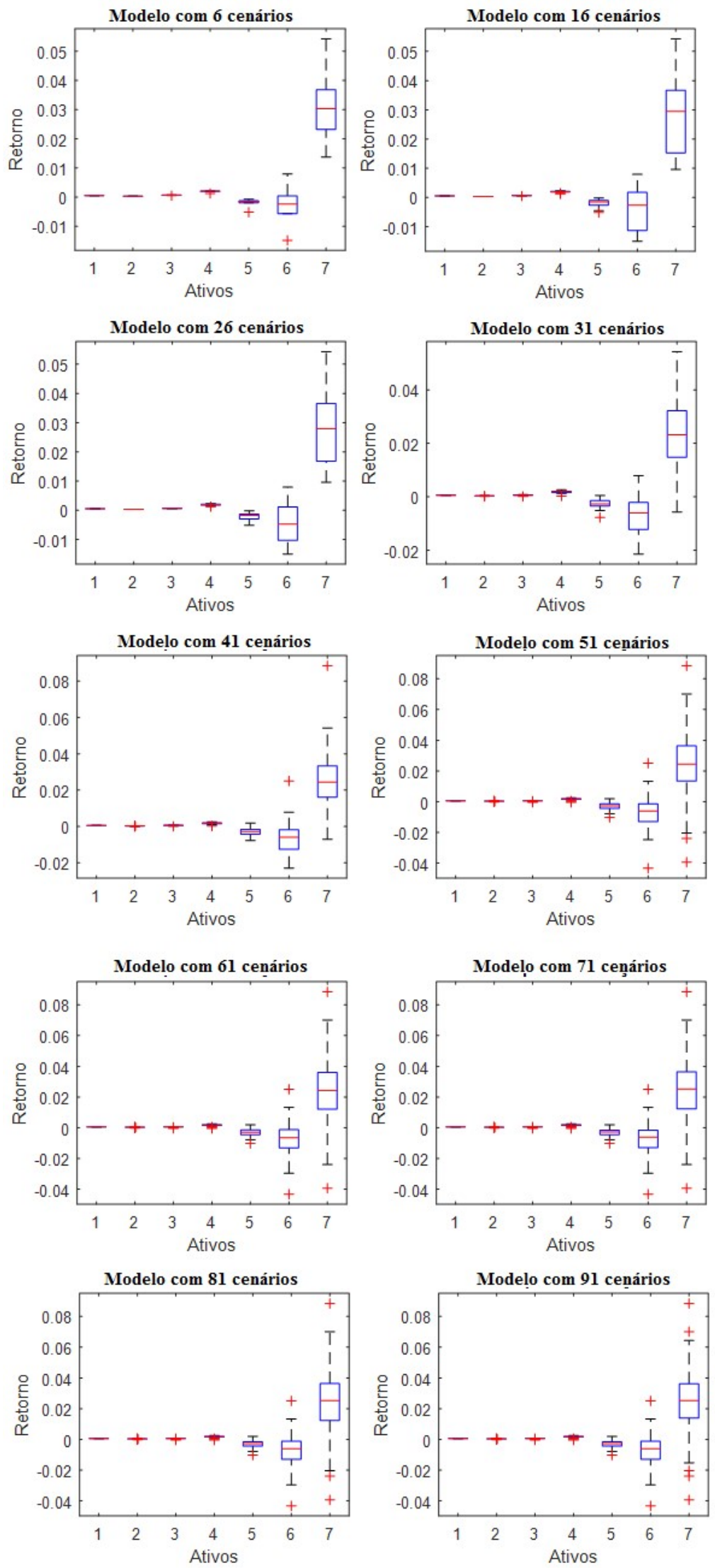

Figura 14: Sensibilidade do retorno pela quantidade de cenários. Fonte: Elaboração Própria 
Foram usados as seguintes quantidades de cenários $6,16,26,31,41,51,61$, $71,81,91$, a programação foi executada para cada um desses casos. O modelo foi aplicado no dia 420 da base (19/10/2015). Os títulos disponíveis são o ativo livre de risco e os títulos prefixados com maturidades de 2 meses, 4 meses, 11 meses, 24 meses, 84 meses e 144 meses, respectivamente.

A cada mudança da quantidadede cenários são reestimados os retornos e refeita a alocação. Os títulos com prazos mais longos têm seus preços mais expostos a alterações na taxa de juros e por isso apresentam mais risco. Geralmente os títulos de longo prazo oferecem um prêmio para compensar o risco adquirido.

Isso fica bem ilustrado na figura 14. Quando as janelas são menores o ativo com a maior maturidade apresenta um retorno bem acima dos outros ativos. Com o aumento da quantidade de cenários a variabilidade do seu retorno aumenta podendo assumir valores extremos tornando-se muito arriscado para o modelo de otimização robusta de pior caso alocar ele na composição da carteira. Com isso, o ativo livre de risco passa a ser a opção de alocação de $100 \%$ do capital disponível. 


\subsubsection{1}

\section{Efeito da variação da quantidade de cenários no retorno}

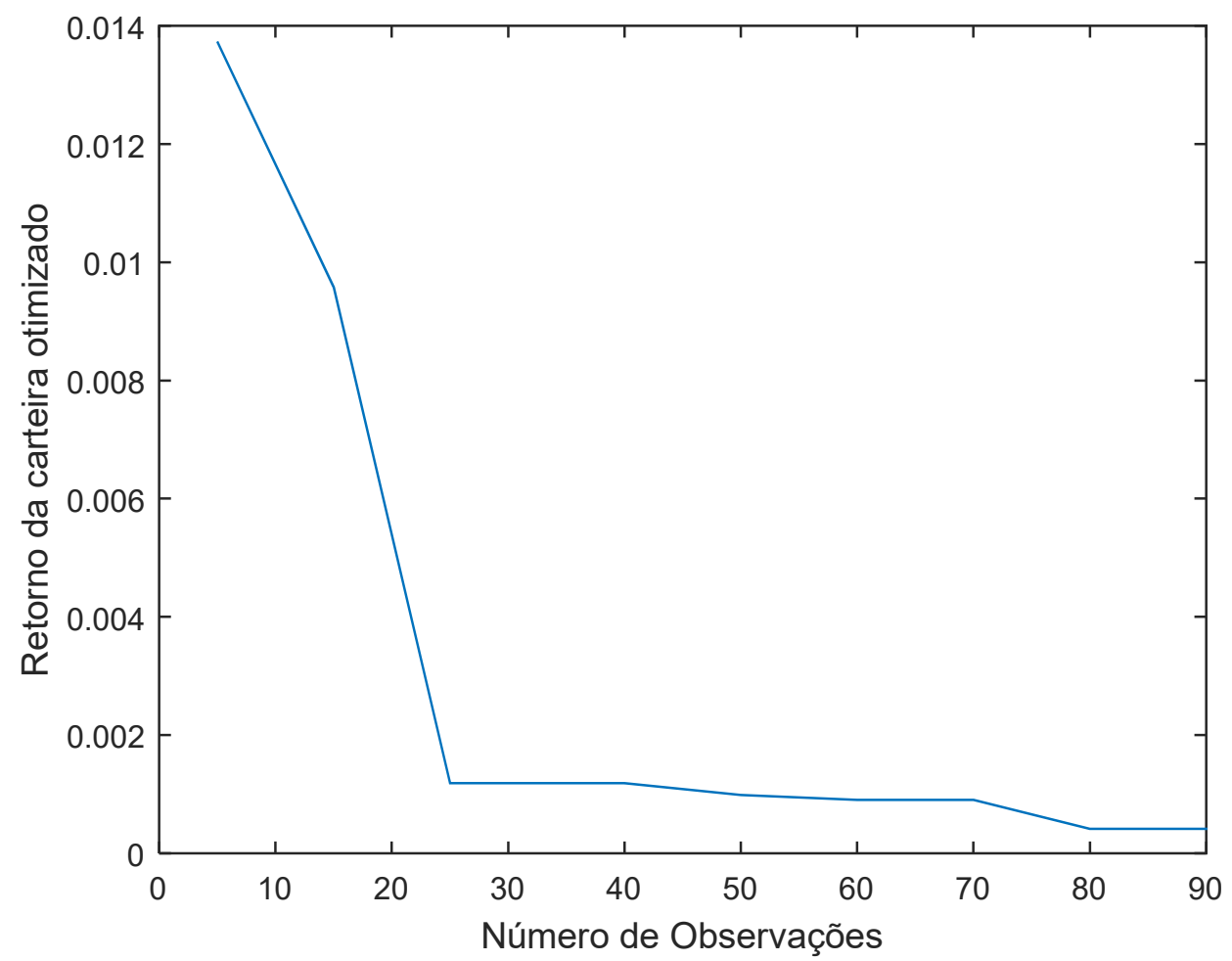

Gráfico 13: Retorno da carteira pela quantidade de cenários. Fonte: Elaboração Própria

O número dos cenários representa a sensibilidade ao risco do investimento, esse é o parâmetro de conservadorismo do modelo. Os cenários menores são para perfis mais arriscados enquanto cenários maiores são para perfis mais conservadores. Quanto maior for a quantidade de cenários, mais o modelo se torna confiável e robusto, pois maior a chance de algum dos cenários previstos se concretizar, por outro lado o excesso de conservadorismo pode resultar em um mau desempenho para as carteiras.

Aumentar o número de cenários é o mesmo que aumentar as restrições e resulta na diminuição da região viável, e com isso o modelo se torna mais pessimista e reduz a performance do método. Todas as restrições devem ser respeitadas simultaneamente. O gráfico 13 mostra claramente esse efeito, a relação inversa entre o retorno e a quantidade de cenários.

O conjunto de pontos na reta são as carteiras eficientes, a escolha vai depender do perfil de risco do investidor. Os pontos abaixo da curva são as carteiras não eficientes e os acima são as carteiras inadmissíveis. 


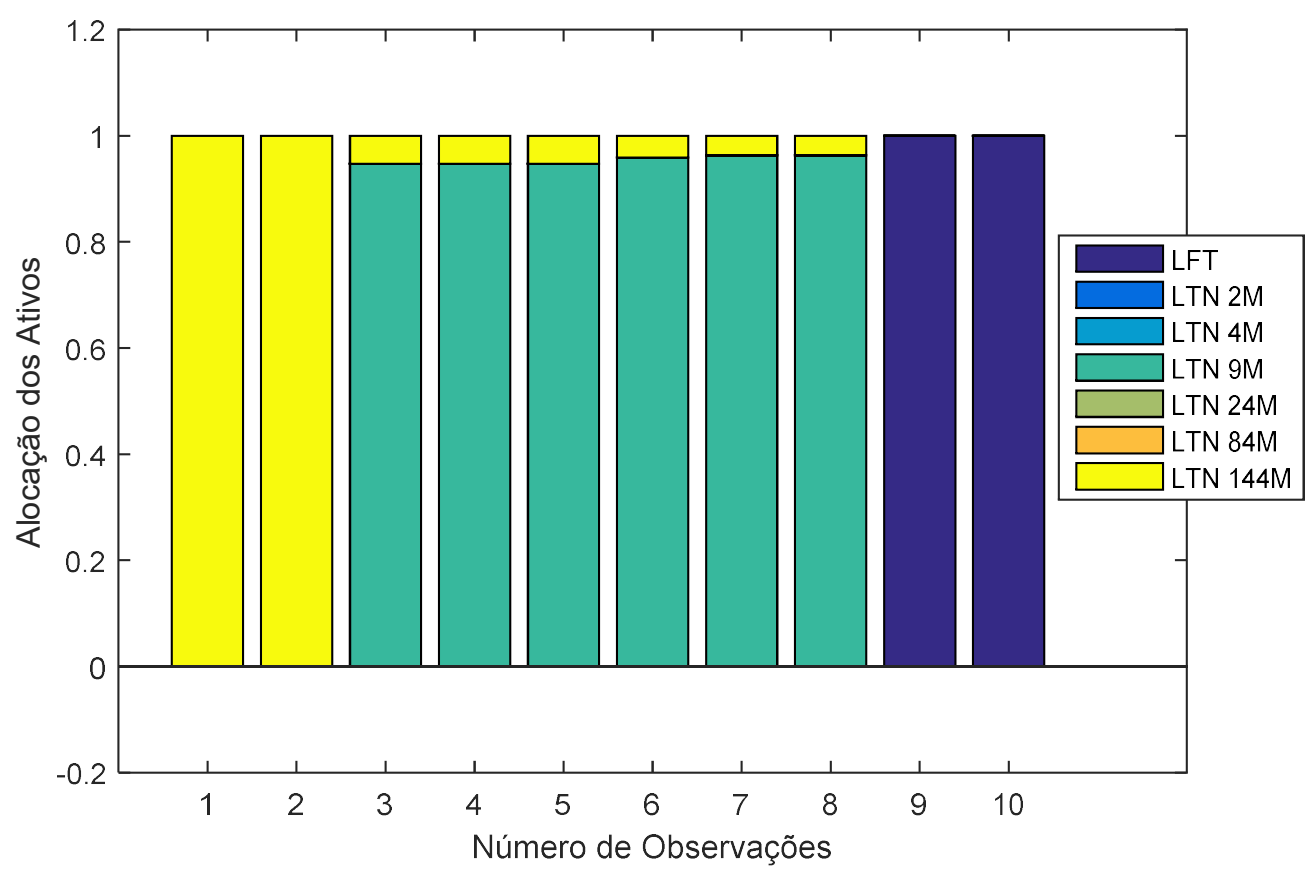

Figura 15: Alocação dos ativos em cada quantidade de cenários. Fonte: Elaboração Própria

A figura 15 mostra que com as janelas menores o modelo aloca $100 \%$ do portfólio no ativo de risco com a maior maturidade. Com o aumento progressivo da quantidade de cenários o modelo passa a alocar em ativos de risco com maturidade menor até alocar $100 \%$ do portfólio apenas no ativo livre de risco. Com essa mudança no comportamento das escolhas da composição da carteira a rentabilidade esperada também reduz.

\subsection{3}

\section{Backtesting}

Um dos aspectos mais importantes da modelagem de otimização de um portfólio é o processo de backtesting. Ele é o instrumento mais utilizado para realizar a validação dos modelos de otimização na área de finanças, pois consegue avaliar se o desempenho dos portfólios em um determinado horizonte de tempo é coerente com o propósito de ser adequado para o uso futuro.

Em suma, um backtesting consiste em um processo matemático de usar como dados séries temporais reais posteriores aos fatos ocorridos para verificar a rentabilidade de forma retroativa de determinada estratégia se ela tivesse sido posta em prática naquele período. Com isso, podem-se verificar os retornos das 
carteiras supostamente eficientes proporcionados no passado e averiguar a coerência entre as dados observados reais e os dados estimados pelo modelo.

No mercado de investimentos, um portfólio é avaliado pela performance obtida em comparação com um benchmarkadequadoe pré-estabelecido. A taxa DI diária foi adotada como benchmark da carteira robusta de renda fixa, ela é o mais importante indicador do desempenho dos investimentos de renda fixa do país. A base de dados usada para a validação dos resultados consiste na série da taxa DI PRÉ Over 252, para o período de 17/02/2014 à 12/04/2016, obtidos na Cetip, são 535 taxas com unidade ao dia.

Para efeito de comparação com o benchmark é necessário o cálculo da rentabilidade acumulada no período. Uma das formas de avaliação é pela diferença entre o retorno obtido pela carteira robusta e o retorno acumulado do benchmark para verificar se os resultados do modelo estão perto da realidade e assim validar a consistência das alocações das carteiras geradas pela otimização.

Foi programado um novo algoritmo e com o novo tratamento dos dados foram recalculadas as novas carteiras ótimas.

Como os retornos dos ativos variam ao longo do tempo é necessário gerar novas alocações ótimas a cada período. Uma forma de analisar esse caso é trabalhar um horizonte temporal de observação móvel com realocações periódicasque será implementado através do uso de uma janela rolante capaz de reproduzir a dinâmica de preços dos ativos.

A realocação periódica consiste em alocar ativos para aquele período e no próximo período se decide entre manter a estrutura da carteira ou alterá-la. $\mathrm{O}$ próximo período começa com o patrimônio final do último período. Ao considerar múltiplos períodos, o retorno obtido no período $\mathrm{n}$ depende das escolhas nos $\mathrm{n}-1$ períodos anteriores. No horizonte rolante o conjunto de incerteza vai sendo atualizando para refletir a dinâmica dos preços ao longo do tempo.

No que se refere à aplicação da janela rolante, será utilizado um horizonte de 253 dias (16/05/2014 - 18/05/2015) e a freqüência de rebalanceamento da composição das carteiras ótimas será diária. O J foi definido em 50, o que representa um valor fixo de 51 cenários, uma estratégia conservadora. Os títulos disponíveis são o ativo livre de risco e os títulos prefixados com maturidades de 2 meses, 4 meses, 11 meses, 24 meses, 84 meses e 144 meses. 


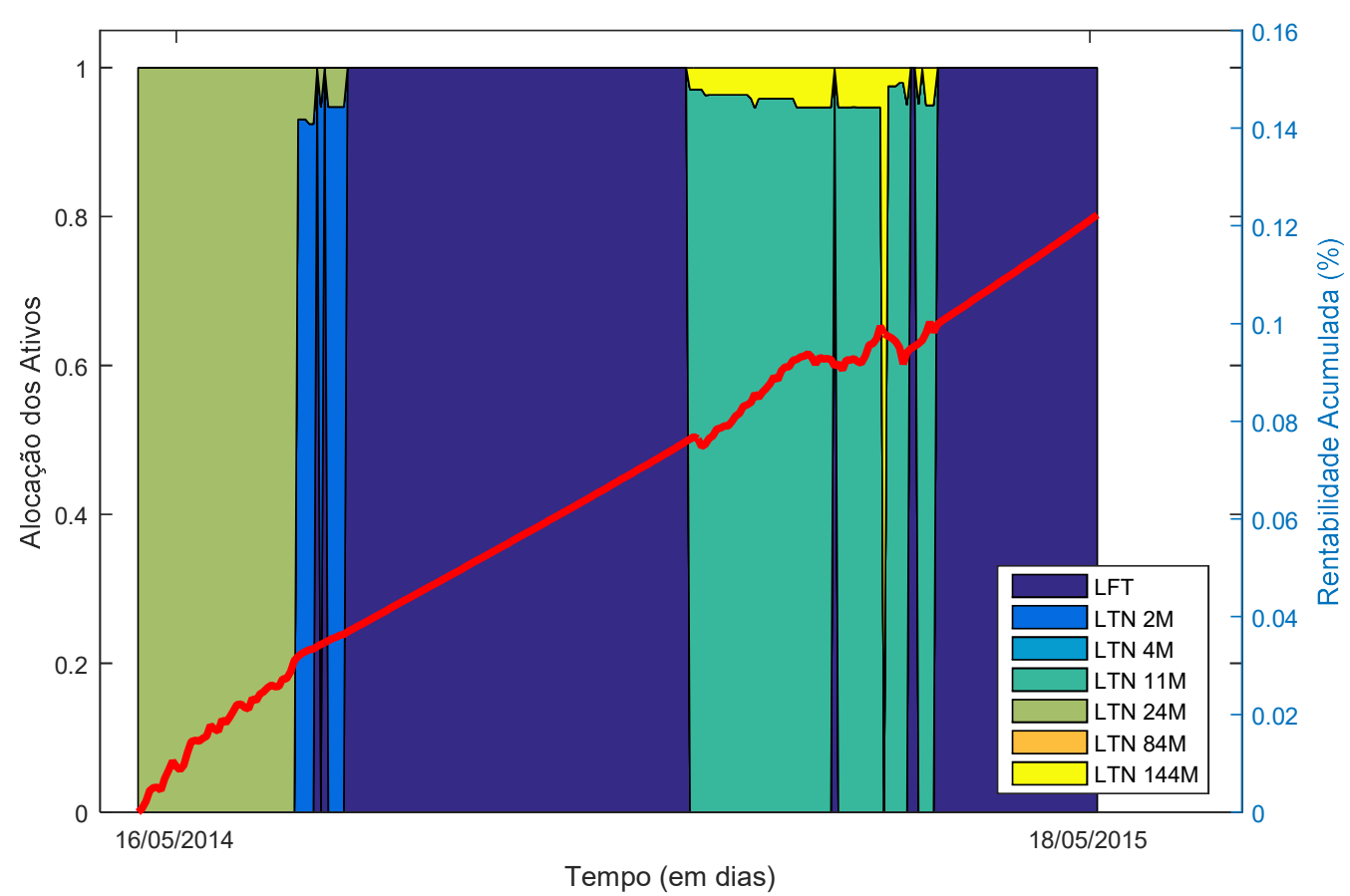

Figura 16: Alocação dos ativos e rentabilidade acumulada ao longo do tempo. Fonte: Elaboração Própria

Ao longo do período foram feitas alocações em diferentes títulos, o que mostra que o modelo de otimização não está tendencioso e realmente se baseia nas condições de mercado representadas no modelo.

Após a execução do programa de otimização, foi realizado o backtesting para medir o desempenho do modelo e comparar a sua rentabilidade o benchmark. A validação do modelo permite a verificação do desempenho real das carteiras geradas pelo modelo de otimização e consistência entre os retornos observados e os retornos previstos pelo modelo.

Através do backtesting pode-se monitorar os resultados e realizar a comparação de desempenho da performance obtida com o modelo robusto e o benchmark de referência do mercado de renda fixa. O backtesting consiste em voltar no tempo e aplicar o peso fornecido pela otimização de cada ativo na carteira séries históricas dos retornos observados para o período de tempo $t+1$.

Para verificar o desempenho da carteira obtida e validar a alocação ótima do modelo, foi calculado o retorno real a partir da precificação dos títulos usando os retornos observadas na realidadeocorridos na data $t+1$, sendo $t$ rolante, usando a participação de cada ativo definida pelo modelo da otimização. 
Foram calculados os rendimentos dos títulos usando o aumento percentual do período de validação. O modelo foi otimista e conseguiu um resultado melhor que o CDI, conforme o gráfico 14 .

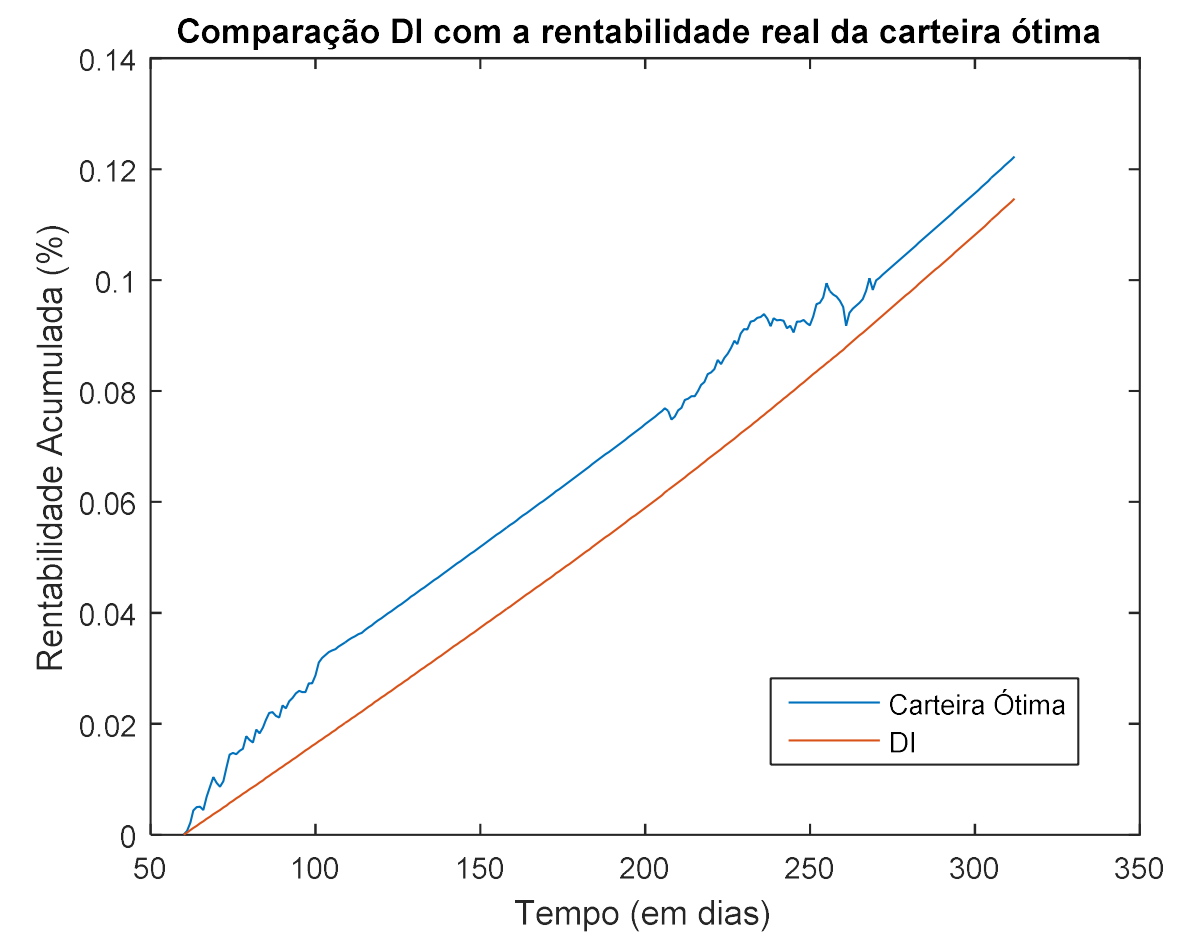

Gráfico 14: Rentabilidade da carteira x rentabilidade do DI. Fonte: Elaboração Própria

As carteiras tiveram desempenho superior ao DI no período geral, mas em períodos específicos seu desempenho foi abaixo do indicador. A carteira robusta teve momentos de rentabilidade negativa, em que se perdeu dinheiro, mas conseguiu se recuperar com boas estratégias. Uma série de boas escolhas no período inicial garantiu o sucesso do período total. O fato de terem ocorrido rentabilidades menores que o CDI mostra que o modelo algumas vezes previu cenários ruins que diferiram muito da realidade e com isso ele prefriu alocar em ativos de risco do que manter na escolha segura do Tesouro Selic.

Em certos períodos a rentabilidade da carteira apresenta a mesma inclinação do CDI. Nesses trechos, pode-se ver que ambos têm o mesmo ritmo de crescimento. Isso significa que nesse período o modelo alocou a maior parte no pós-fixado, o Tesouro Selic, e como, já foi mencionado, as taxas Selic e CDI andam juntos.

Os resultados forneceram evidências de que a metodologia usada cumpriu seu papel robusto e conseguiu maximizar os resultados, queapresentarm performance melhor que o indicador referenciado do mercado. Além dos bons 
resultados do modelo robusto em comparação ao benchmark, nota-se que ele se mostra bem condizentes coma realidade, o que significa que os cenários criados foram bem elaborados.

\subsection{4}

\section{Crise e sem crise}

A estratégia de investimento robusta foi construída para funcionar bem em todos os cenários econômicos e a realocação periódica permite alterar a estratégia de alocação sempre que necessário. Será realizada a alocação pelo modelo com objetivo de examinara influência de períodos de crise econômica. Foram escolhidos dois dias de análise representativos dentro da amostra que permitam a comparação.

Para a execução da programação o $\mathrm{J}$ foi definido em 20 , o que representa um valor fixo de 21 cenários. Os títulos disponíveis são o ativo livre de risco e os títulos prefixados com maturidades de 2 meses, 4 meses, 11 meses, 24 meses, 84 meses e 144 meses.

A figura 17 apresenta o conjunto de retornos previstos para cada um desses dias, que representam um dia de crise $(\mathrm{t}=410 ; 02 / 10 / 2015)$ e um dia sem crise $(\mathrm{t}=100 ; 15 / 07 / 2014)$. O conjunto de incertezas dos ativos de risco é definido como a região poliédrica convexa dos retornos estimados previstos. Para ser feita a análise de retornos de ativos de curto e longo foram selecionados 24 meses e 84 meses. 


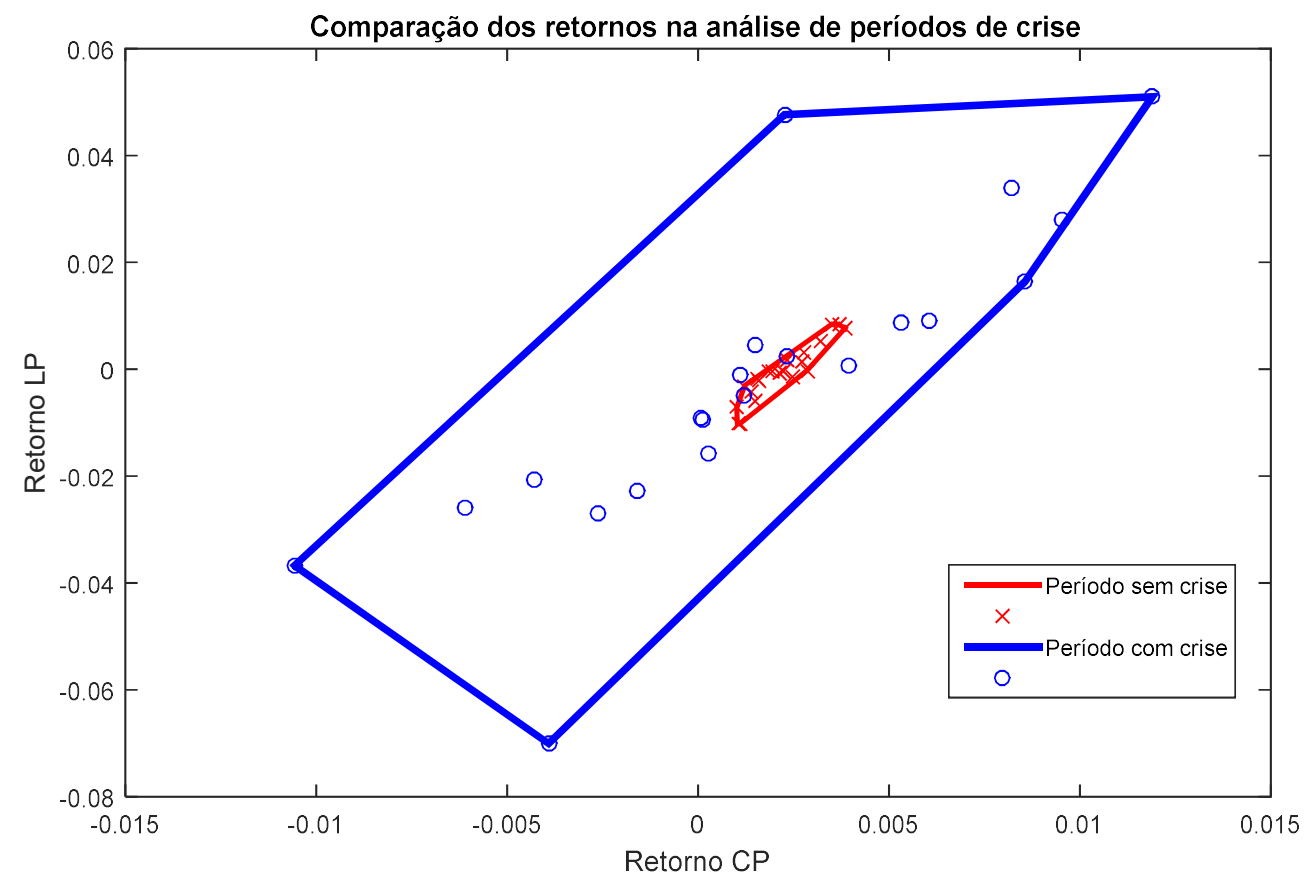

Figura 17: Análise de crise - Retorno LP e CP (\%). Fonte: Elaboração Própria

Eram esperados certos comportamentos, esses pontos foram analisados e comprovados pelo modelo. Pela figura 17 podemos ver:

- A variação dos retornos de curto prazo é bem inferior à variação do retorno de longo prazo.

- O período sem crise tem relação linear.

- Os retornos previstos dos títulos de curto prazo e de longo prazo têm positiva.A janela de dados do período sem crise é pequena e em torno de zero, já o período de crise tem os dados espalhados e vai incluir na sua região viável os retornos previstos de períodos sem crise.

- A relação de quedas comparativas entre o retorno previsto de dois ativos (um de curto prazo e outro de longo prazo) que mostra que um tem o pior caso muito maior que o outro e vice versa.

Os modelos robustos de pior caso, por serem mais conservadores em cenários de crise, costumam ter melhores resultados que outros modelos de otimização devido à postura mais defensiva, nesses casos eles alocam tudo no ativo livre de risco. Mais uma vez o modelo desenvolvido apresenta resultados dos testes retratando as condições de mercado e sendo representativo da realidade.

O dia representativo do não crise alocará $100 \%$ do capital disponível em um título prefixado de longa maturidade, LTN 24M. 


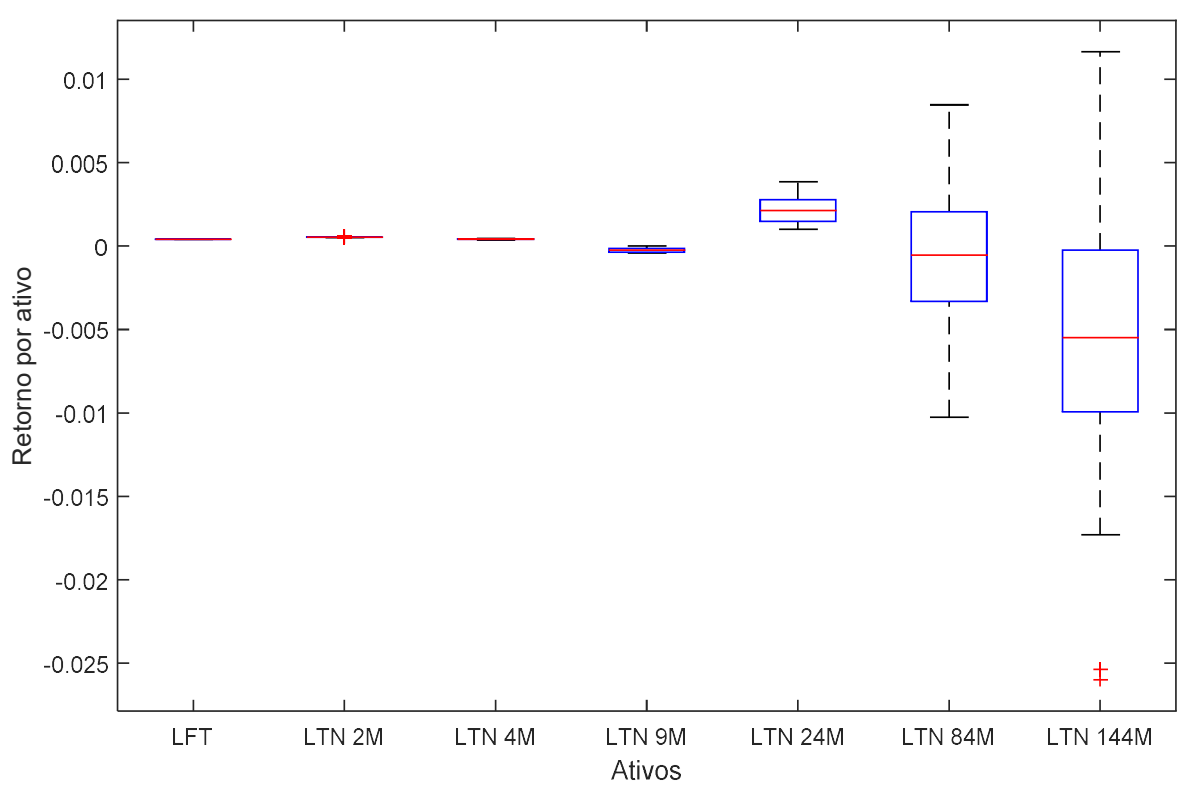

Figura 18: Retorno dos ativos - Dia sem crise. Fonte: Elaboração Própria

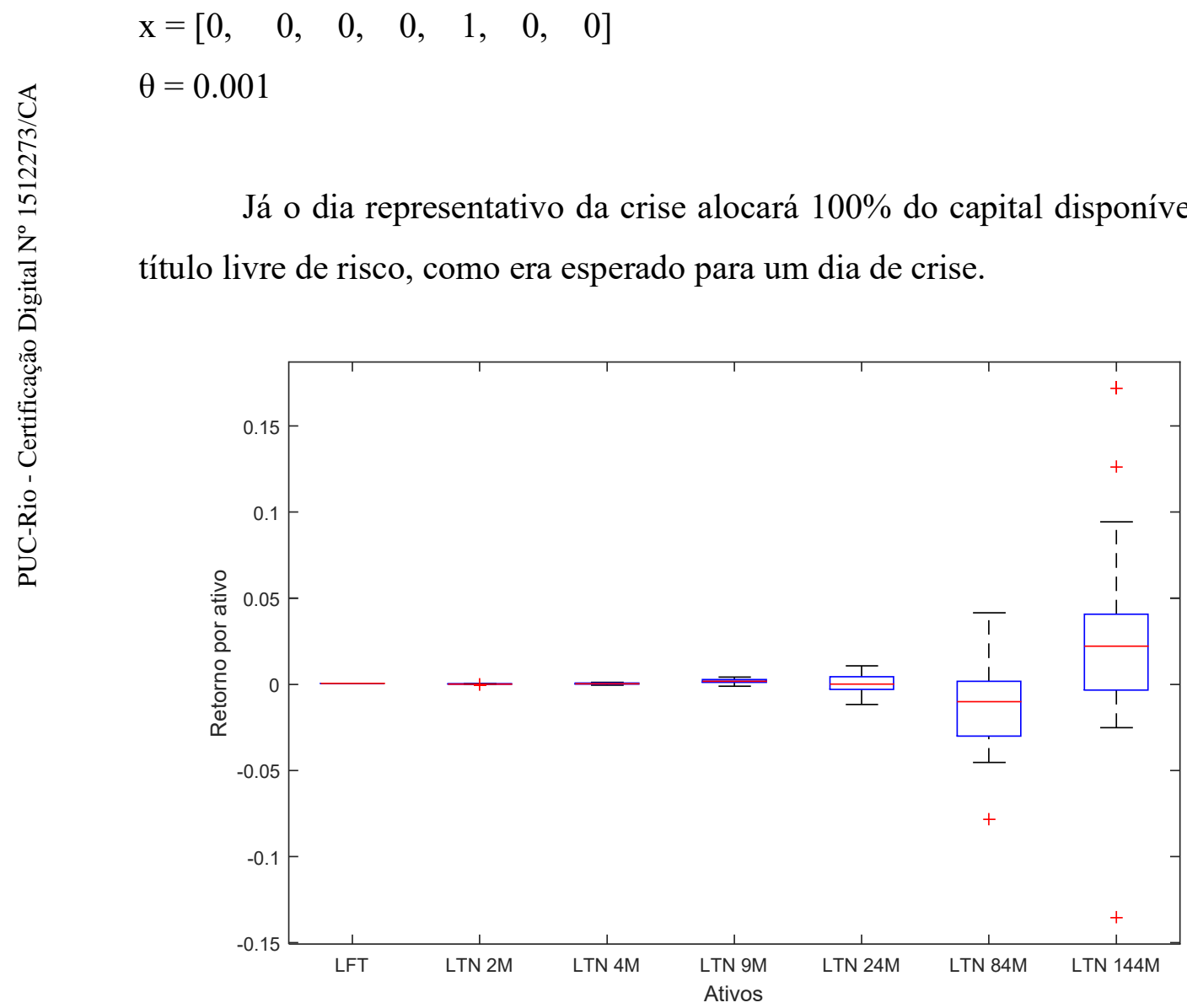

Figura 19: Retorno dos ativos - Dia com crise. Fonte: Elaboração Própria

$\mathrm{x}=\left[\begin{array}{lllllll}1, & 0, & 0, & 0, & 0, & 0, & 0\end{array}\right]$

$\theta=0,000525$ 
Quando os ativos têm tendência de baixa, a região viável se torna menor e o modelo desloca-se para100\% no ativo livre de risco, já que a venda a descoberto não é permitido. Em uma nova análise, assumindo o caso de não existir o ativo livre de risco como opção de investimento, foi removido o Tesouro Selic da lista de ativos no modelo de otimização e foi executado novamente o programa para um dia de crise.

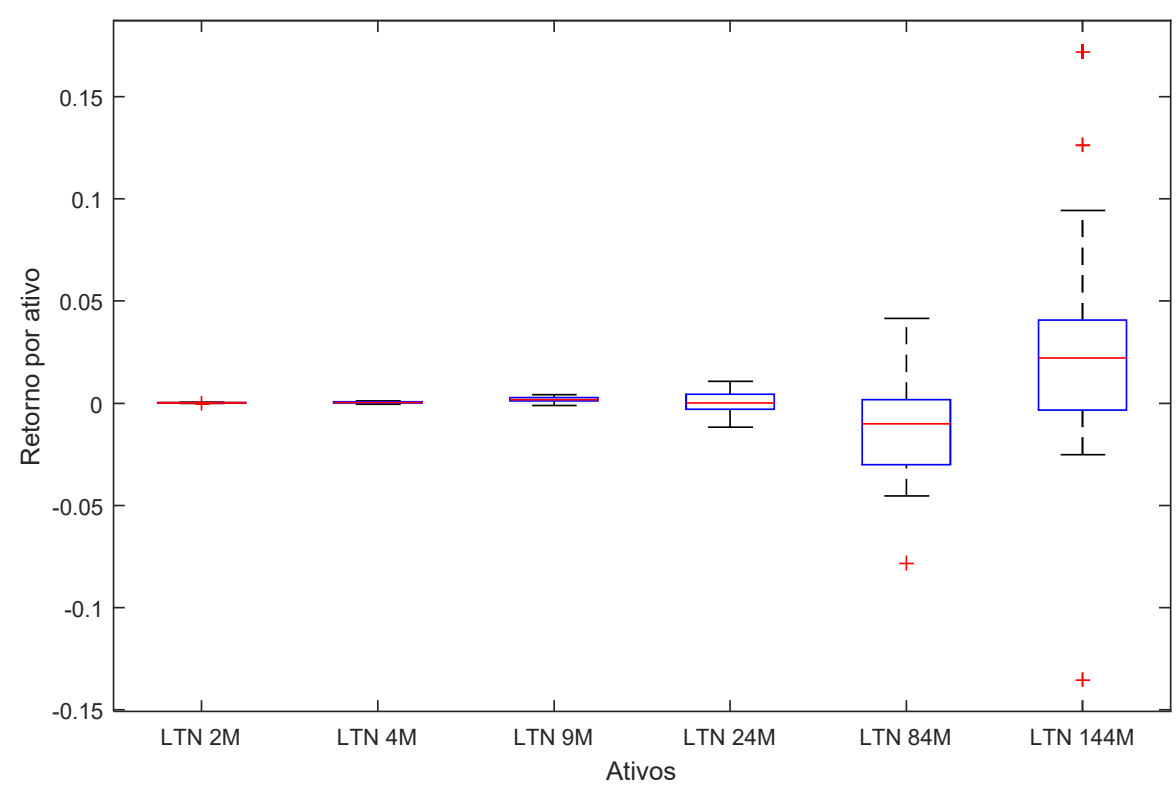

Figura 20: Retorno dos ativos - Dia com crise (sem ativo livre de risco). Fonte: Elaboração Própria $\mathrm{x}=\left[\begin{array}{llllll}0.8432, & 0, & 0.1568, & 0, & 0, & 0\end{array}\right]$ $\theta=-2.0686 \mathrm{e}-04$

Quando retirado o ativo livre de risco o modelo faz uma nova alocação dividindo o capital disponível em percentuais expressivos por dois ativos, LTN $2 \mathrm{M}$ e LTN 9M. O resultado do da carteira para o período é negativo, o que prova que é fundamental em toda carteira ter a possibilidade de alocação em um ativo livre de risco, porque mesmo que o ganho investindo nele seja pequeno é possível evitar perdas com alocações de risco em períodos desfavoráveis. 


\subsection{5}

\section{Lâmina de fundo de investimento}

Considerando que a metodologia adotada fosse usada por um fundo de investimento para compor uma carteira de renda fixa arrojada, a lâmina do fundo seria apresentada de forma similar ao exposto nessa parte do estudo.

Foram usados 51 cenários para auxiliar o cálculo do retorno de cada dia ( $\mathrm{J}=50)$. O período de análise foi de 09/05/2014 à 09/12/2015. A gestão ativa do portfólio de investimentos busca obter rentabilidade superior aos índices referenciais de mercado para o segmento de renda fixa.

Informações

Aplicação Inicial: R $\$ 1.000,00$

Composição da carteira: Títulos prefixados e títulos pós-fixados

Grau de Risco: Baixo

Objetivo: Proporcionar aos seus cotistas rendimentos superiores aos oferecidos por instrumentos de renda fixa/Acompanhar a variação da taxa de juros/ Superar o desempenho do CDI.

Desempenho do fundo: $105,03 \%$ do CDI (09/05/2014 - 09/12/2015)

Saldo bruto acumulado: R $\$ 1.213,99$

Rentabilidade: Se você tivesse aplicado R\$ 1.000,00 (mil reais) no fundo em 09/05/2014 e não houvesse realizado outras aplicações, nem solicitado resgates durante o ano, em 09/12/2015, você poderia resgatar R $\$ 1.213,99$

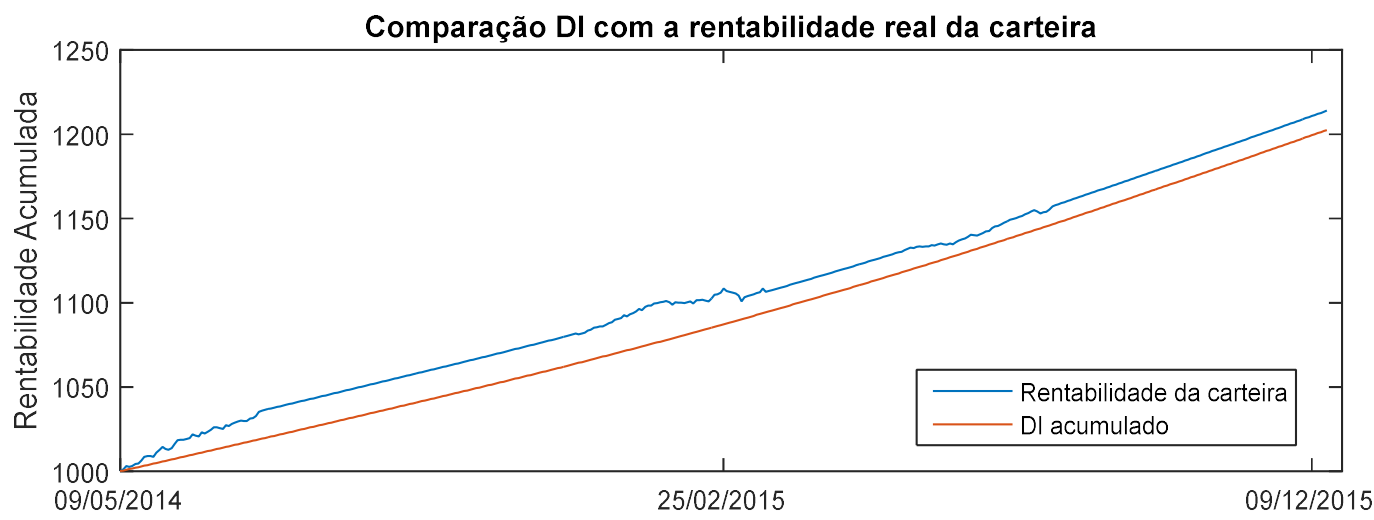

Gráfico 15: Patrimônio acumulado comparado com o DI acumulado. Fonte: Elaboração Própria 
O gráfico 15 mostra o retorno acumulado diariamente da estratégia adotada pelo modelo robusto e o DI acumulado. O retorno da estratégia acompanha o DI em vários períodos, porque a estratégia adotada pelo modelo é alocar quase $100 \%$ no ativo livre de risco que é a Selic que como já vimos nesse trabalho tem comportamento similar ao DI.

A estratégia de investimento da carteira robusta apresentou um melhor desempenho em termos de retorno acumulado, as carteiras do fundo seguiram o mercado de renda fixa, rendendo mais durante boa parte do período.

\subsubsection{1}

\section{Trailing Return (períodos de 3M, 6M e 1A)}

A rentabilidade do período que compreende o valor investido e o valor de resgate final da aplicação pode ser obtida através da fórmula:

$$
R=\frac{V_{r}}{V_{i}}-1
$$

Sendo:

$R=$ Rentabilidade para o período

$V_{r}=$ Valor de resgate

$V_{i}=$ Valor investido

O trailing return mede o desempenho por um período de tempo e é a comparação entre o benchmark de referência do mercado e o retorno do fundo em um horizonte rolante fixo. Em termos práticos de mercado, o trailing return mostra o retorno de um período que um fundo poderia ter ganho voltando a entrada nele em uma data no passado, obedecendo a um intervalo fixo. É usado para avaliar se o fundo é uma boa opção de investimento ou não baseado na sua performance passada.

Seguem as representações gráficas para os períodos de 3 meses, 6 meses e 1 ano que correspondem ao tempo de permanência no fundo, usando um modelo com 44 cenários. A rentabilidade tanto do fundo quanto à do CDI é calculada para esses períodos dia a dia. 
Trailing Return de 3 meses

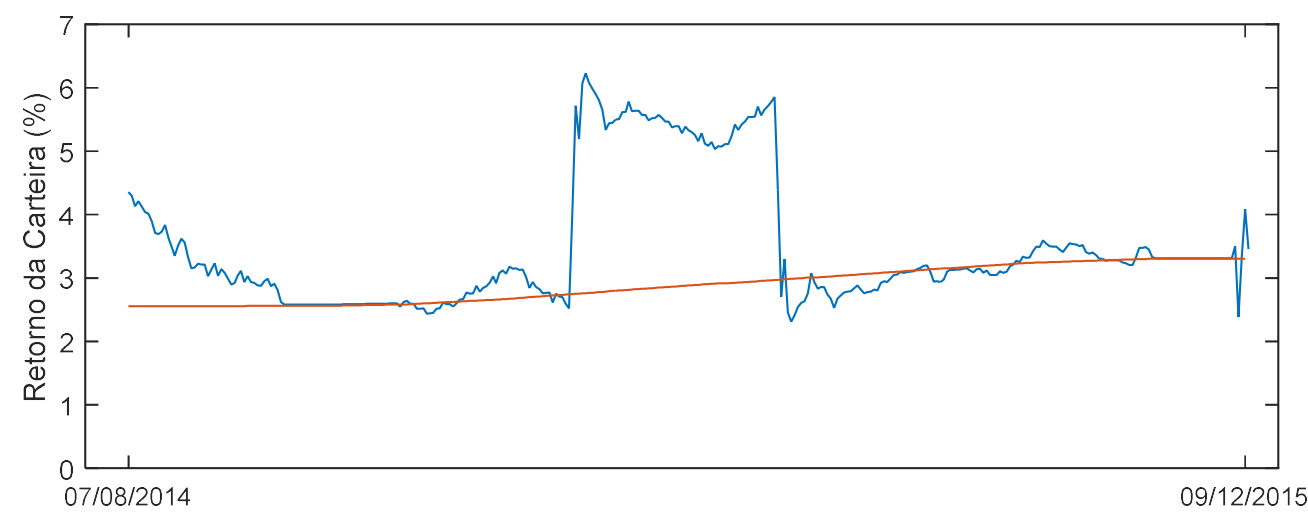

Gráfico 16: Trailing Return de 3 meses. Fonte: Elaboração Própria

Trailing Return de 6 meses

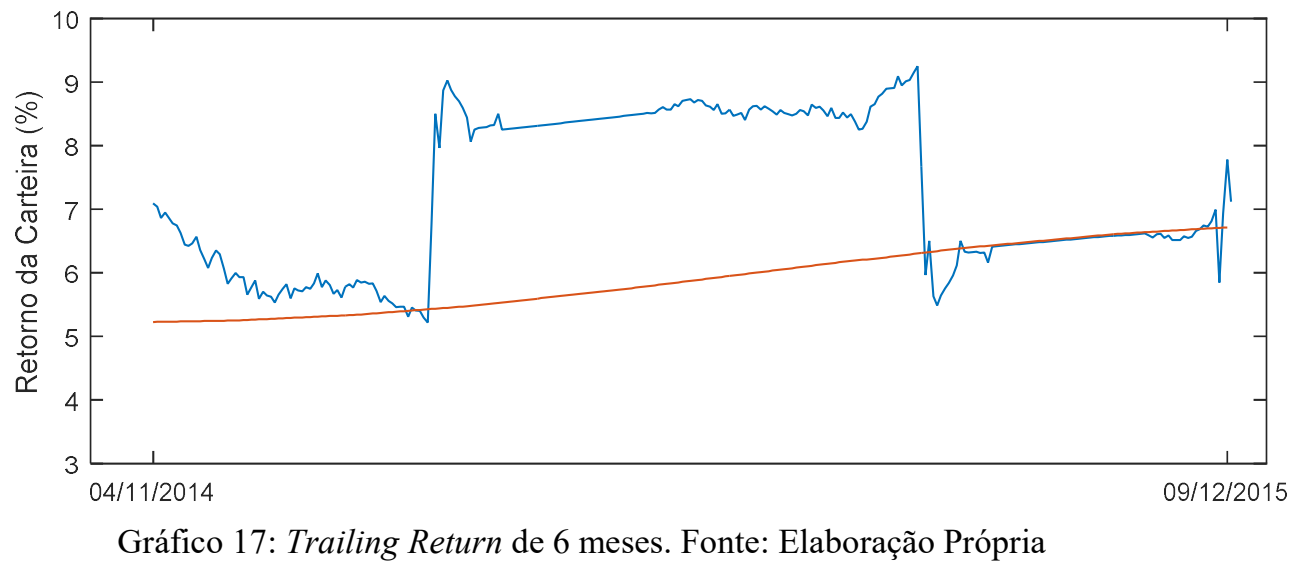

Trailing Return de 1 ano

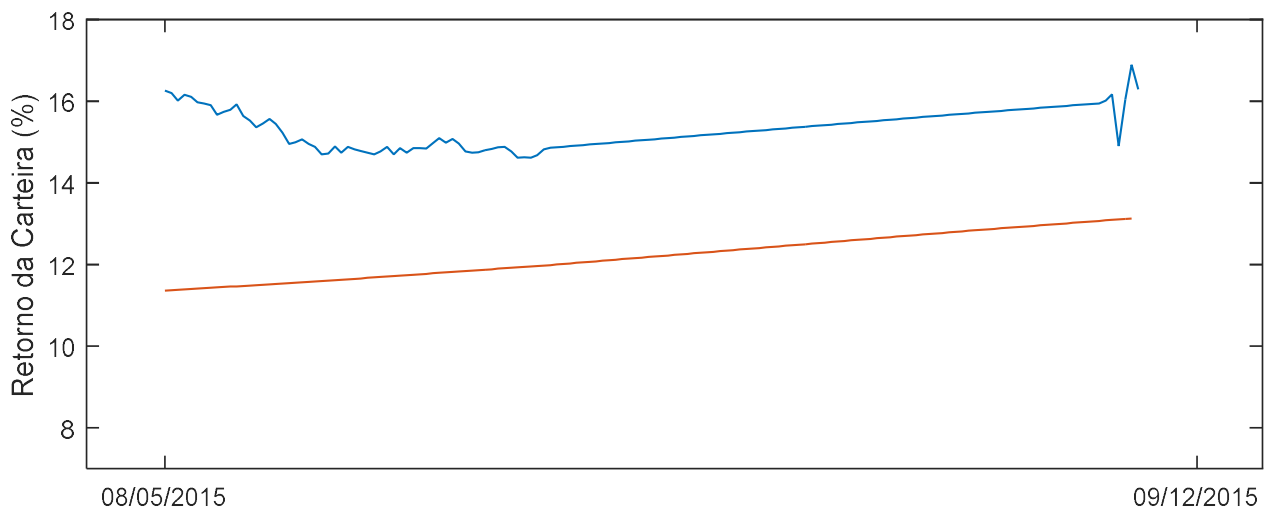

Gráfico 18: Trailing Return de 1 ano. Fonte: Elaboração Própria

Os investimentos de 3 meses e de 6 meses apresentaram variações mais abruptas do que um investimento com um prazo maior como 1 ano. Isso pode ser 
explicado pelo período de alta instabilidade econômica e política do país que contava com um cenário conturbado marcado por aumentos recordes de inflação e de desemprego, e também a progressiva elevação da taxa Selic. Quando o investimento é de curto prazo ele fica mais sujeito aos impactos do ambiente econômico. Nas três análises de tempo o fundo performou bem comparado ao DI.

\subsubsection{2}

\section{Desempenho do fundo como percentual do CDI252}

Fazendo uma comparação do desempenho do fundo medido em percentuais do CDI, a estratégia do modelo de otimização supera o CDI em diversos períodos como se pode ver nos gráficos 19, 20 e 21. No entanto, houve períodos que o CDI performou melhor dependendo do período de permanência no fundo.

Acima da linha horizontal representa quando o fundo teve performance mais que $100 \%$ do CDI e abaixo da linha menos que $100 \%$ do CDI.

3 meses

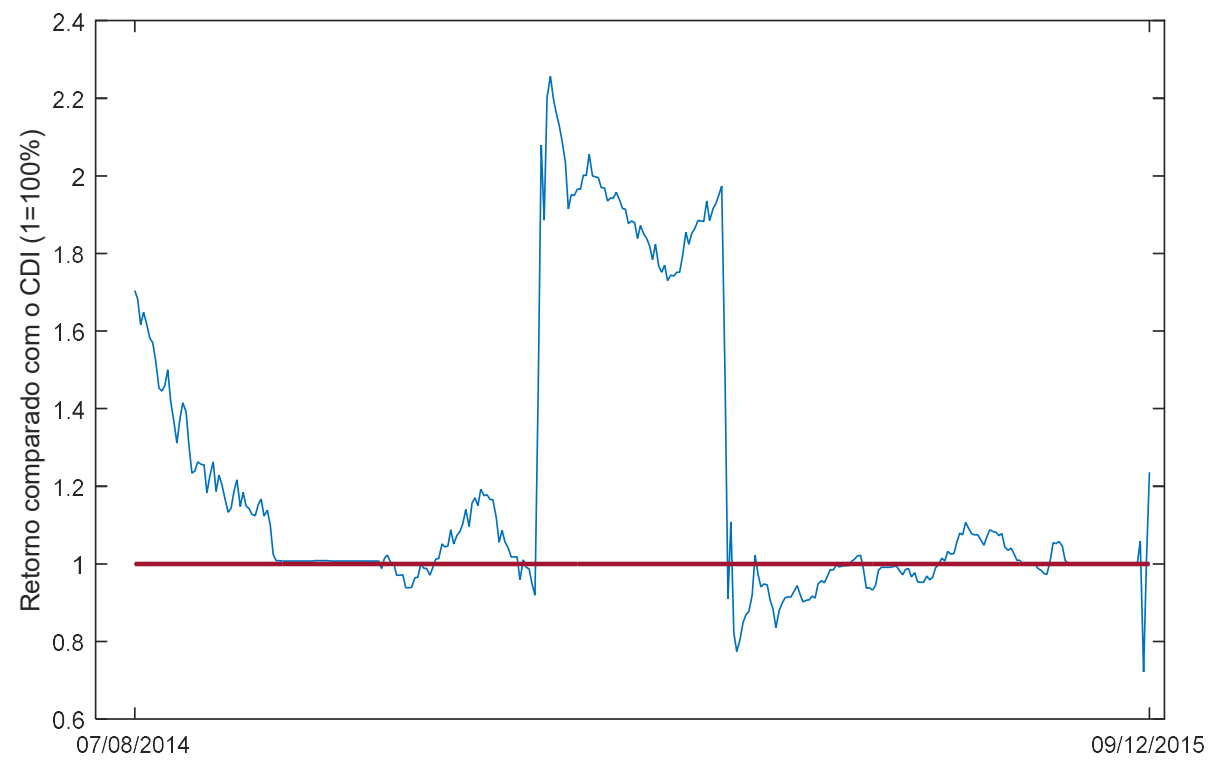

Gráfico 19: Desempenho do fundo em percentuais do CDI252 - 3 m. Fonte: Elaboração Própria 
6 meses

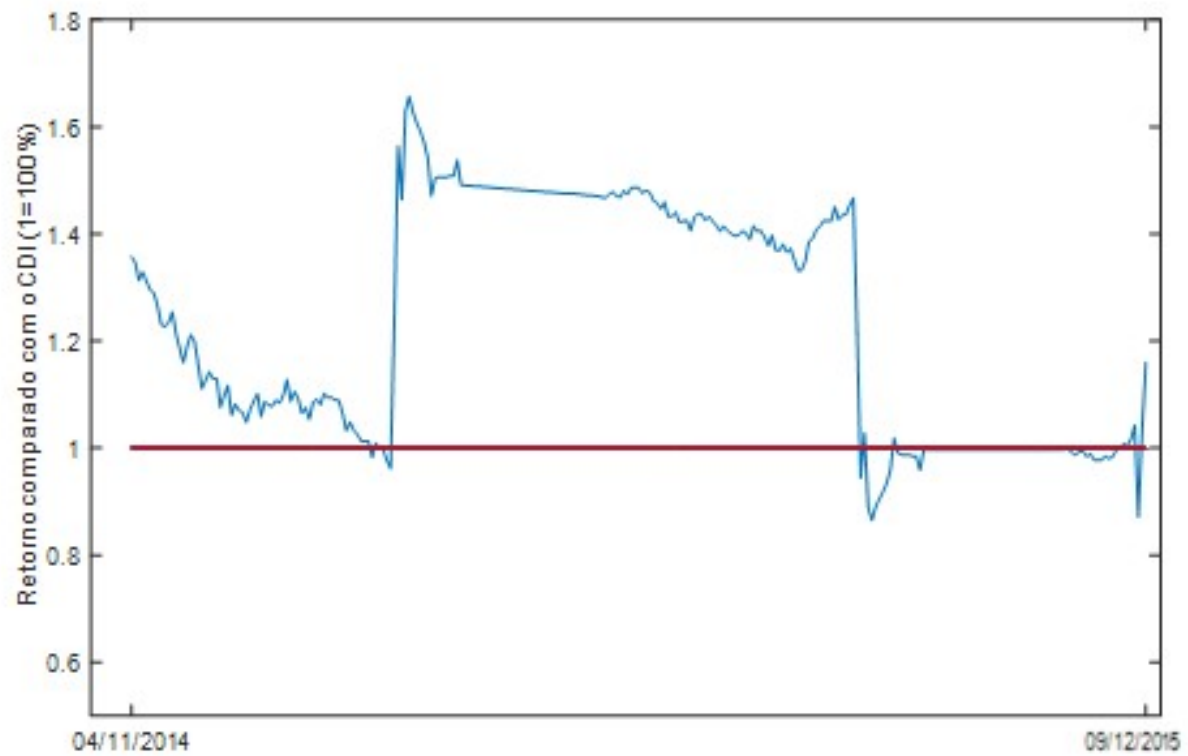

Gráfico 20: Desempenho do fundo em percentuais do CDI252 - 6 m. Fonte: Elaboração Própria

1 ano

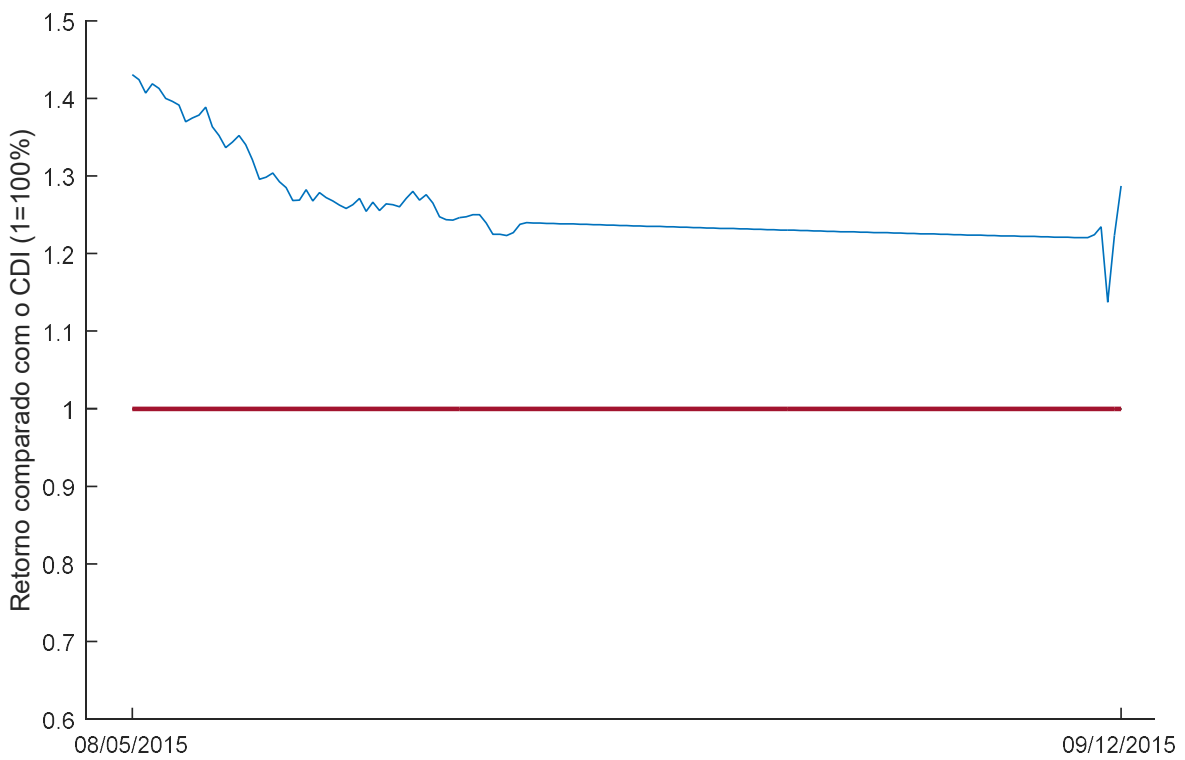

Gráfico 21: Desempenho do fundo em percentuais do CDI252 - 1 ano. Fonte: Elaboração Própria

Como o interesse do presente estudo é obter carteiras ótimas através de um modelo de otimização robusta que tem como marca incorporar as incertezas, observou-se que nesse caso as estimativas tiveram consistência, devido a sua 
coerência de resultados na sua utilização em condições reais de mercado de renda fixa.

Apesar de esse modelo robusto ser uma análise de pior caso, ele pode produzir resultados melhores do que os obtidos pelo índice do mercado de renda fixa principalmente em mercados com alta volatilidade. Os comportamentos descritos e analisados foram compatíveis com o comportamento da realidade e diversos tópicos de finanças conseguiram ser abordados.

\subsection{6}

\section{Índice Sharpe}

O índice Sharpe (SHARPE, 1994) mede a relação entre o risco e o retorno de uma carteira de investimentos. Ele permite avaliar se o retorno é resultado de bons investimentos ou se é fruto do excesso de risco assumido na posição estabelecida, mas deve ser utilizado apenas para comparar produtos financeiros com características semelhantes.

O índice é um instrumento de apoio à tomada de decisão pelo qual é possível decidir qual a melhor estratégia. Considerando que comparando um investimento conservador e um arrojado, o retorno esperadodo primeiro provavelmente é menor para ser condizente com o menor risco assumido, o índice Sharpe é extremamente útil, pois fornece uma medida única que avalia essa relação e permite estabelecer uma comparação.

A fórmula do índice tem em seu numerador a rentabilidade média real da carteira, ou seja, o quanto o retorno excedeu o retorno do mercado (do benchmark). Já no denominador é um indicativo da volatilidade da carteira no período, ou seja, é o desvio padrão que mede a oscilação dos retornos da carteira e por isso é uma medida de risco. Se o desvio padrão for alto, significa que os retornos previstos têm alta volatilidade. Em resumo, o índice mostra o quanto de retorno foi acrescentado na carteira para cada unidade acrescentada de risco, por isso são desejados maiores valores para o índice.

$$
S R=\frac{\bar{r}_{p}-r_{f}}{\sigma_{p}}
$$


Onde:

$\bar{r}_{p}=$ retorno esperado do portfólio

$r_{f}=$ retorno livre de risco

$\sigma_{p}=$ desvio padrão da carteira

Para realizar a análise do índice Sharpe é usado o horizonte rolante e a artifício da mudança da quantidade de cenários. As estratégias arrojada e conservadora têm 21 e 44 cenários, respectivamente.

Alocações de cada estratégia no período:

Estratégia arrojada

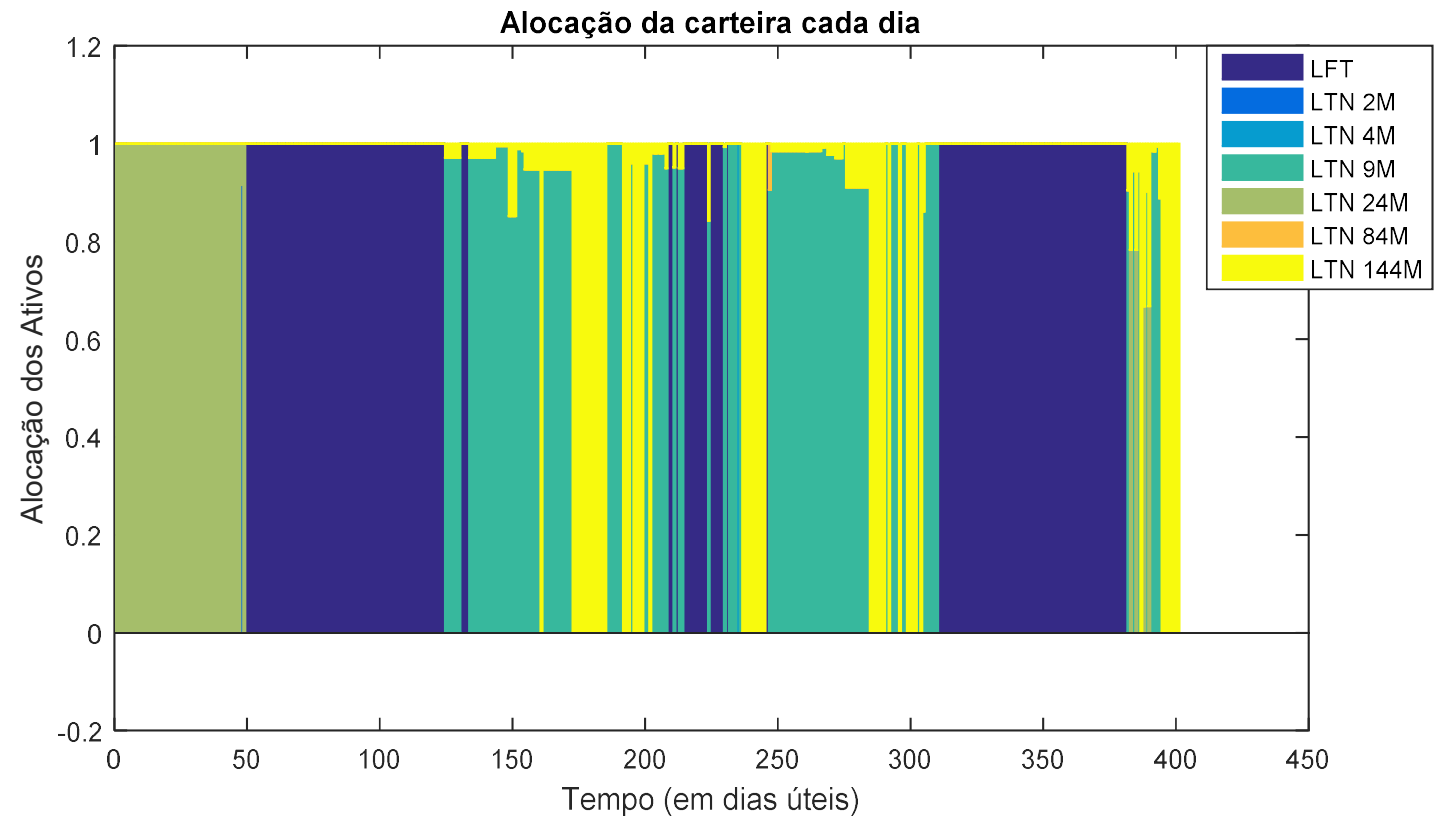

Figura 21: Alocação ao longo do tempo - Estratégia Arrojada. Fonte: Elaboração Própria 
Estratégia conservadora

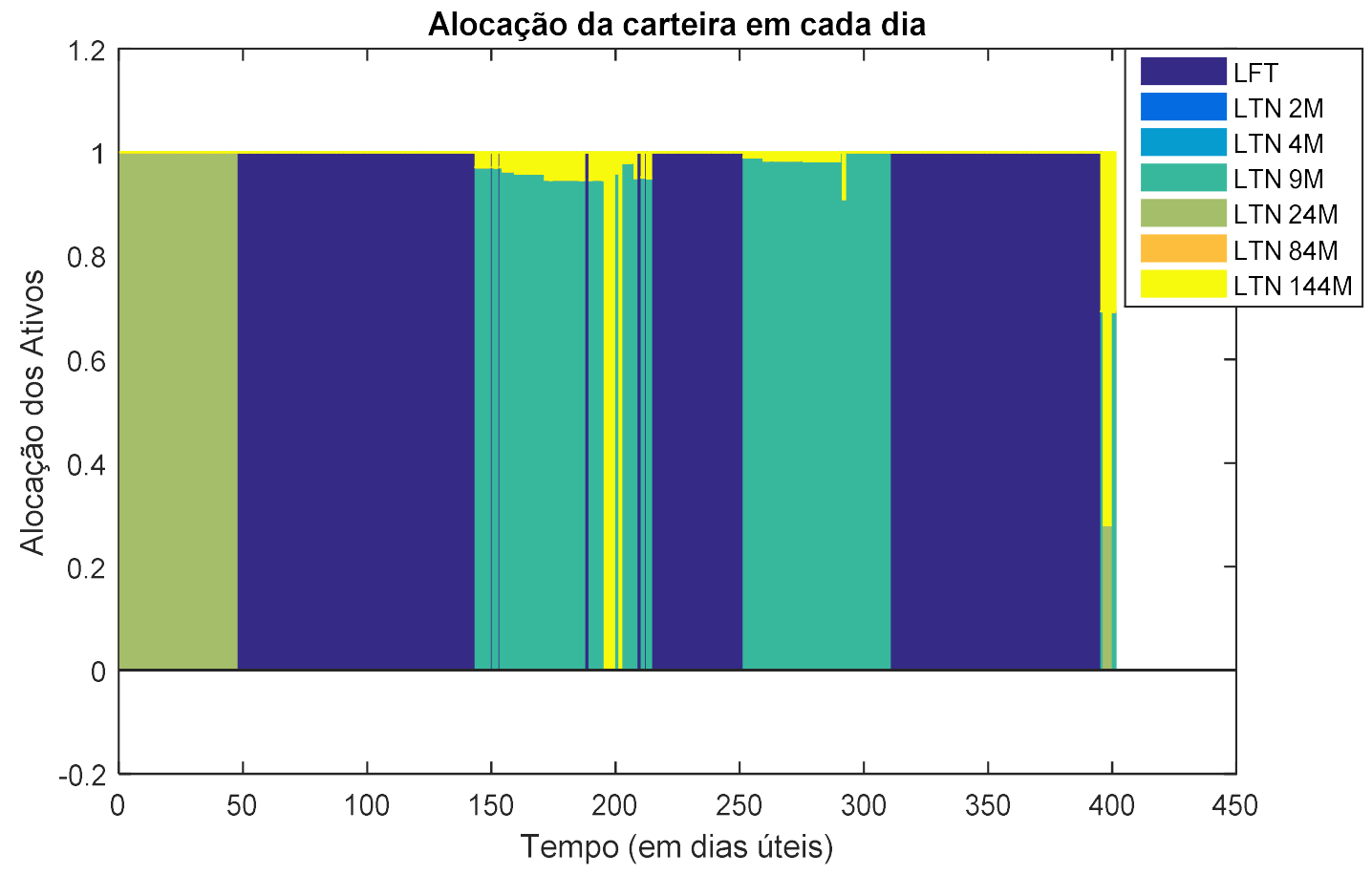

Figura 22: Alocação ao longo do tempo - Estratégia Conservadora. Fonte: Elaboração Própria

Pela alocação dos ativos na carteira de investimento em cada estratégia pode-se observar, nas figuras 21 e 22 , que ao longo do tempo o investidor de perfil conservador aloca muitas vezes o capital no ativo livre de risco enquanto o de perfil arrojado aloca em títulos de longo prazo que possibilitam maior retorno, mas como consequência tem maior risco devido à maior exposição. Essa representação ilustra as variáveis que serão usadas no índice Sharpe.

Foi calculado o Índice Sharpe considerando investimentos no fundo no período de 3 meses, 6 meses e 1 ano.

3 meses

Tabela 1: Índice Sharpe das estratégias - 3 meses. Fonte: Elaboração própria.

\begin{tabular}{|c|c|c|c|}
\hline Estratégias & $\boldsymbol{\mu 3 m}$ & $\boldsymbol{\sigma 3 m}$ & Índice Sharpe \\
\hline Arrojado & 1.3446 & 1.2533 & 1.0744 \\
\hline Conservador & 1.2124 & 0.3644 & 3.3323 \\
\hline
\end{tabular}


Baseado no índice Sharpe considerando o período de 3 meses de investimento a estratégia conservadora é a mais indicada.

6 meses

Tabela 2:Índice Sharpe das estratégias - 6 meses. Fonte: Elaboração própria.

\begin{tabular}{|c|c|c|c|}
\hline Estratégias & $\mu 6 \mathrm{~m}$ & $\sigma 6 \mathrm{~m}$ & Índice Sharpe \\
\hline Arrojado & 1.4379 & 0.5782 & 2.4916 \\
\hline Conservador & 1.2353 & 0.2182 & 5.6721 \\
\hline
\end{tabular}

Baseado no índice Sharpe considerando o período de 6 meses de investimento a estratégia conservadora é a mais indicada.

1 ano

Tabela 3: Índice Sharpe das estratégias - 1 ano. Fonte: Elaboração própria.

\begin{tabular}{|c|c|c|c|}
\hline Estratégias & $\mu 1 \mathrm{~A}$ & $\boldsymbol{\sigma 1 A}$ & Índice Sharpe \\
\hline Arrojado & 1.5270 & 0.2041 & 7.5084 \\
\hline Conservador & 1.2570 & 0.0521 & 24.1870 \\
\hline
\end{tabular}

Baseado no índice Sharpe considerando o período de 1 ano de investimento a estratégia conservadora é a mais indicada. E pode-se ver que foi mais interessante permanecer um longo período no fundo. 


\section{Conclusão}

A gestão de carteiras retrata a alocação de capital disponível e limitado em ativos que satisfaçam o perfil do investidor ou do fundo de investimento na relação risco e retorno. $\mathrm{O}$ uso de modelagem e métodos de otimização aplicados à tomada de decisões financeiras é presente na literatura e no mercado.

Ao longo desse trabalho, foi realizada a implementação de um modelo de otimização robusta de pior caso para alocação de títulos de renda fixa que calcula a melhor escolha de alocação dentre os valores de pior cenário. A otimização robusta permite incorporar a incerteza diretamente no processo de otimização usando um conjunto poliédrico definido de previsões dos retornos. Os cenários possíveis de retornos fazem parte das restrições que devem ser obedecidas simultaneamente. $\mathrm{O}$ estudo trabalha com títulos públicos prefixados e pós fixados e captura a dinâmica de preço do mercado através das curvas de juros.

Foi vista a importância da taxa de juros na perspectiva econômica, que constitui a base para as estimações e previsões dos componentes do modelo da curva de juros, da precificação dos títulos e do cálculo da matriz de retornos um passo a frente.

O modelo de curva utilizado se ajustou bem e captura os movimentos da taxa de juros, quando ela cai o preço do ativo aumenta podendo gerar ganhos na venda e é possível controlar a estratégia baseado nessas oscilações. A metodologia utilizada para estimar a previsão dos retornos foi eficiente e foi possível controlar o conservadorismo com as mudanças dos parâmetros do modelo.

A abordagem proposta de realizar diferentes análises para avaliar a aplicação do modelo robusta na seleção de carteiras conseguiu verificar a variabilidade dos retornos em função das maturidades, a comparação da curvas prevista com a curva real, o efeito na alocação e no retorno com a mudança da quantidade de cenários e a comparação de períodos de crise com períodos sem crise. 
Pelo backtesting, as carteiras otimizadas tiveram bons resultados e o modelo teve sucesso em evitar perdas. Foram comparadas as performances financeiras obtidas na aplicação do modelo e dos indicadores de benchmark através da rentabilidade acumulada, O desempenho das carteiras ótimas foi satisfatório. A análise similar à lâmina de fundo com o trailing return, o percentual do CDI e índice Sharpe cumpriram o papel de replicar as informações disponibilizadas aos investidores pelas gestoras e a sua utilização permitiu avaliar que teria sido uma boa aplicaçãofinanceira se fosse real.

Os resultados alcançados levam à conclusão que o modelo construído tem boa adaptação, apresenta resultados satisfatórios e comportamento realista. Em termos computacionais o modelo também se mostrou viável.

Esse trabalho espera ter contribuído para o estudo de otimização robusta no uso prático de seleção de carteiras de renda fixa. Os resultados são vistos como promissores e existem oportunidades futuras para continuação da pesquisa com a alteração da especificação do erro de previsão para o beta, com a utilização de outros instrumentos financeiros, podendo ser incluídos ativos não correlacionados, e com a aplicação de modelo em uma série maior de dados. A gestão de carteiras quando realizada com ferramentas que garantam sua robustez e eficácia possibilita rentabilidade maior que o benchmark de referência do mercado para investidores e fundos de investimentos. 
6

\section{Referências bibliográficas}

ARTZNER, P. et al. Coherent Measures of Risk. Mathematical Finance, v. 9, n. 3, p. 203-228, 1999.

BEN-TAL, A.; NEMIROVSKI, A. Robust Convex Optimization. Mathematics of Operations Research, v. 23, n. 4, p. 769-805, 1998.

BEN-TAL, A.; NEMIROVSKI, A. Robust solutions of uncertain linear programs. Operations Research Letters, v. 25, n. 1, p. 1-13, 1999.

BERTSIMAS, D.; PACHAMANOVA, D. Robust multiperiod portfolio management in the presence of transaction costs. Computers and Operations Research, v. 35, n. 1, p. 3-17, 2008.

BERTSIMAS, D.; PACHAMANOVA, D.; SIM, M. Robust linear optimization under general norms. Operations Research Letters, v. 32, n. 6, p. 510 516, 2004.

BERTSIMAS, D.; SIM, M. The Price of robustness. Operations Research, v. 52, n. 1, p. 35-53, 2004.

CORNUEJOLS, G.; TÜTÜNCÜ, R. Optimization Methods in Finance. [s.I.] Cambridge University Press, 2006.

DEMIGUEL, V.; NOGALES, F. Portfolio Selection with Robust Estimation. Operations Research, v. 57, n. 3, p. 560-577, 2007.

DIEBOLD, F. X.; LI, C. Forecasting the term structure of government bond yields. Journal of Econometrics, v. 130, n. 2, p. 337-364, 2006.

DIEBOLD, F. X.; LI, C.; YUE, V. Z. Global yield curve dynamics and interactions: A dynamic Nelson-Siegel approach. Journal of Econometrics, v. 146, n. 2, p. 351-363, 2008.

DONALD R. CHAMBERS, WILLARD T. CARLETON, D. W. W. A New Approach to Estimation of the Term Structure of Interest Rates. The Journal of Financial and Quantitative Analysis, v. 19, n. 3, p. 233-252, 1984.

DUPAČOVÁ, J.; KOPA, M. Robustness of optimal portfolios under risk and 
stochastic dominance constraints. European Journal of Operational Research, v. 234, n. 2, p. 434-441, 2014.

FABOZZI, F. J. et al. Robust Portfolio Optimization and Management. [s.I.] Wiley, 2007.

FABOZZI, F. J.; HUANG, D.; ZHOU, G. Robust portfolios: Contributions from operations research and finance. Annals of Operations Research, v. 176, n. 1, p. 191-220, 2010.

FABOZZI, F. J.; PACHAMANOVA, D. A. Simulation and Optimization in Finance. [s.l.] Wiley, 2010.

FABOZZI, F. J.; PACHAMANOVA, D. A. Portfolio Construction and Analytics. [s.I.] Wiley, 2016.

FERNANDES, B. et al. An adaptive robust portfolio optimization model with loss constraints based on data-driven polyhedral uncertainty sets. European Journal of Operational Research, v. 255, n. 3, p. 961-970, 2016.

GOLDFARB, D.; IYENGAR, G. Robust Portfolio Selection Problems. Mathematics of Operations Research, v. 28, n. 1, p. 1-38, 2003.

GREGORY, C.; DARBY-DOWMAN, K.; MITRA, G. Robust optimization and portfolio selection: The cost of robustness. European Journal of Operational Research, v. 212, n. 2, p. 417-428, 2011.

HALLDÓRSSON, B. V; TÜTÜNCÜ, R. An Interior-Point Method for a Class of saddle-point problems. Journal of Optimization Theory and Applications, v. 116, n. 3, p. 559-590, 2003.

KLEIN, R. W.; BAWA, V. S. The effect of estimation risk on optimal portfolio choice. Journal of Financial Economics, v. 3, n. 3, p. 215-231, 1976.

KOLM, P. N.; TÜTÜNCÜ, R.; FABOZZI, F. J. 60 Years of portfolio optimization: Practical challenges and current trends. European Journal of Operational Research, v. 234, n. 2, p. 356-371, 2014.

LU, Z. Robust portfolio selection based on a joint ellipsoidal uncertainty set. Mathematical Programming, v. 126, n. 1, p. 193-201, 2011.

LUENBERGER, D. G. Investment Science. New York: Oxford University Press, 1998.

MARKOWITZ, H. Portfolio Selection. The Journal of Finance, v. 7, n. 1, 
p. 77-91, 1952.

NELSON, C. R.; SIEGEL, A. F. Parsimonious Modeling of Yield CurvesThe Journal of Business. The Journal of Business, v. 60, n. 4, p. 473-489, 1987.

NEUMANN, J. V.; MORGENSTERN, O. Theory Of Games And Economic Behavior. [s.I.] Princeton University Press., 1944.

RUSTEM, B.; HOWE, M. Algorithms for Worst-case Design and Applications to Risk Management. [s.I.] Princeton University Press., 2002.

SANTOS, A. A. P. The Out-of-Sample Performance of Robust Portfolio Optimization. Revista Brasileira de Financas, v. 8, n. 2, p. 141-166, 2010.

SHARPE, W. F. Capital asset prices: A theroy of market equilibrium under conditions of risk. The Journal of Finance, v. 19, n. 3, p. 425-442, 1964.

SHARPE, W. F. A Linear Programming Approximation for the General Portfolio Analysis Problem. The Journal of Financial and Quantitative Analysis, v. 6, n. 5, p. 1263-1275, 1971.

SHARPE, W. F. The Sharpe Ratio. The Journal of Portfolio Management, v. 21, n. 1, p. 49-58, 1994.

SOYSTER, A. L. Convex Programming with Set-Inclusive Constraints and applications to Inexat Linear Programming. Operations Research, v. 21, n. 5, p. 1154-1157, 1973.

Tesouro Nacional - Ministério da Fazenda. Tesouro Direto. Disponível em: http://www.tesouro.fazenda.gov.br/tesouro-direto> Acesso em 08/08/2016.

TÜTÜNCÜ, R.; KOENIG, M. Robust asset allocation. Annals of Operations Research, v. 132, n. 1-4, p. 157-187, 2004. 